\title{
Articles
}

\section{Judicial Deference to Executive Precedent}

\section{Thomas W. Merrill†}

In 1984, the Supreme Court adopted a new framework for determining when courts should defer to interpretations of statutes by administrative agencies. Previous decisions had looked to multiple contextual factors in answering this question. ${ }^{1}$ Chevron U.S.A., Inc. v. National Resources Defense Council, $I n c^{2}$ appeared to reject this approach and require that federal courts defer to any reasonable interpretation by an agency charged with administration of a statute, provided Congress has not clearly specified a contrary answer. The Court justified this new general rule of deference by positing that Congress has implicitly delegated interpretative authority to all agencies charged with enforcing federal law. ${ }^{3}$

Chevron is widely regarded as a kind of "counter-Marbury" for the administrative state. ${ }^{4}$ Indeed, read for all it is worth, the decision would make admin-

\footnotetext{
$†$ Professor of Law, Northwestern University School of Law. I served as Deputy Solicitor General, Department of Justice, from 1987 to 1990 , during which time I argued or helped brief a large number of the Supreme Court cases involving the "Chevron doctrine." The analysis of these cases (and all others pending while I was with the Justice Department) is strictly my own, and not necessarily the same as that of the Justice Department or its client agencies. I wish to thank Justice Antonin Scalia, the 1991 Howard J. Trienens Visiting Judicial Fellow at Northwestern School of Law, and my colleagues at Northwestern for a stimulating discussion at a faculty workshop. Special thanks to Robert Bennett, Steven Calabresi, Charlotte Crane, Keith Hylton, Paul Larkin, Gary Lawson, Marty Redish, and Peter Schuck for comments on an earlier draft, and to Melissa McGonigal for her diligent research assistance.

1. See infra notes 7-29 and accompanying text.

2. 467 U.S. 837 (1984).

3. Id. at $843-44,865-66$.

4. Cass R. Sunstein, Law and Administration Afier Chevron, 90 ColuM. L. Rev. 2071, 2075 (1990).
} 
istrative actors the primary interpreters of federal statutes and relegate courts to the largely inert role of enforcing unambiguous statutory terms. This in turn would have enormous implications for the overall balance of power among the three branches of government. Executive branch agencies would gain new power to achieve rapid changes in policy through reinterpretation of their legislative authority; courts would play a diminished role in checking agency aggrandizement and in protecting reliance interests associated with past interpretations; and Congress, unable to rely on the courts to honor unstated institutional understandings, could react by enacting excruciatingly detailed statutes or intensifying the use of oversight hearings.

This Article has two primary tasks. The first, which is the subject of Parts I, II, and III, is to determine whether Chevron in fact operates in the Supreme Court as the "counter-Marbury" portrayed by commentators. It turns out that the Court does not regard Chevron as a universal test for determining when to defer to executive interpretations: the Chevron framework is used in only about half the cases that the Court perceives as presenting a deference question. Nor have the multiple factors identified in the pre-Chevron period disappeared; to the contrary, the Court continues to rely upon them in many cases, despite their apparent irrelevance under Chevron. Perhaps most strikingly, in recent Terms the application of Chevron has resulted in less deference to executive interpretations than was the case in the pre-Chevron era. Thus, instead of functioning as a "counter-Marbury," there are signs that Chevron is being transformed by the Court into a new judicial mandate "to say what the law is." I will argue that the failure of Chevron to perform as expected can be attributed to the Court's reluctance to embrace the draconian implications of the doctrine for the balance of power among the branches, and to practical problems generated by its all-or-nothing approach to the deference question.

The second task of the Article is to propose an alternative to Chevron that avoids its theoretical and practical failings and is more congruent with the actual practice of the Supreme Court. Part IV sets forth what I call the "executive precedent model." The root idea is that executive interpretations should be viewed as a form of precedent and integrated into the process of statutory construction in much the same way that judicial precedent is integrated. The model begins with the understanding that both the executive branch and the judicial branch have inherent authority to interpret enacted law-and thus to generate "precedent" construing that law. The model then posits that the judicial power includes not only the power to determine whether to follow past judicial precedent interpreting enacted law, but also the power to determine what weight to give to past executive precedent construing that law. Under the proposed model, courts would treat executive precedent approximately the same way they regard the precedent of another court of coordinate jurisdiction: as prima facie

5. Marbury v. Madison, 5 U.S. (1 Cranch) 137, 177 (1803). 
correct, and as entitled to more or less deference depending on various contextual factors (such as the thoroughness with which the executive agency considered the issue, how long the executive interpretation has been followed, and so forth).

Part V compares Chevron's deference model and the executive precedent model. Chevron rests on a principle of mandatory deference: courts are compelled to defer to agency interpretations because Congress has directed them to defer. The executive precedent model, in contrast, rests on a principle of discretionary deference: courts defer to executive interpretations because sound judicial decisionmaking requires that they follow the precedent of a coordinate branch of government. I contend that the discretionary deference principle implicit in the executive precedent model fits better within the constitutional and legal framework that gave rise to the modern administrative state, provides a unifying theory explaining why the traditional factors supposedly banished by Chevron are relevant and how they relate to ordinary modes of judicial interpretation, and offers better incentives than does Chevron for principled decisionmaking by courts, agencies, and Congress.

\section{Chevron: The Revolution on PAPER}

The attitude of courts toward administrative interpretations of statutes has ranged between two extremes. ${ }^{6}$ At one pole, courts ignore the administrative view. When operating in this "independent judgment" mode, a court employs traditional tools of statutory interpretation-analysis of text, legislative history, and various canons of construction-to arrive at what it regards as the best interpretation of the statute, just as it would in a case where the executive branch has not spoken previously. At the other pole, courts frame the inquiry in terms of whether the administrative interpretation is one that a reasonable interpreter might embrace. In this "deference" mode, a court implicitly acknowledges that the statute is susceptible to multiple readings. The task of the court is viewed not as discovering the best interpretation, but rather as assuring that the executive view does not contradict the statute and otherwise furthers legitimate objectives.

Chevron is widely understood to mark a significant transformation in the Supreme Court's jurisprudence of deference. This part spells out the support

6. See Pittston Stevedoring Corp. v. Dellaventura, 544 F.2d 35, 49 (2d Cir. 1976) (Friendly, J.) (noting two extremes in judicial attitude toward administrative statutory interpretation), aff' $d$ sub nom. Northeast Marine Terminal Co. v. Caputo, 432 U.S. 249 (1977); 5 KenNETH C. Davis, AdMINistrative LaW TREATISE 403 (2d ed. 1984) (same); Nathaniel L. Nathanson, Administrative Discretion in the Interpretation of Statutes, 3 VAND. L. REV. 470 (1950) (distinguishing between occasions when courts require agency interpretations to be "correct" and when they require such interpretations to be merely reasonable). In recent literature, the standard terms for the two poles, which I will use here, are "independent judgment" and "deference." See, e.g., Cynthia R. Farina, Statutory Interpretation and the Balance of Power in the Administrative State, 89 ColUM. L. REV. 452, 453-54 \& n.10 (1989); Henry P. Monaghan, Marbury and the Administrative State, 83 CoLUM. L. REv. 1, 6-7 (1983). 
for this view by briefly examining the pre-Chevron decisional law and contrasting it with the framework set forth in Chevron. After describing the revolutionary potential of Chevron, I will turn in the next part to a consideration of how Chevron has in fact affected the practice of the Supreme Court.

\section{A. Pre-Chevron: The Multiple Factors Regime}

Prior to 1984, the Supreme Court had no unifying theory for determining when to defer to agency interpretations of statutes. The approach was instead pragmatic and contextual. One feature of the Court's practice was that deference could range over a spectrum from "great" to "some" to "little" 8 (although no attempt was ever made to calibrate different degrees of deference with any precision). A particularly common approach was to cite the views of those charged with administration of the statute as one of several reasons for adopting a particular construction. Thus, the Court might embrace a particular interpretation (1) because it was supported by the language of the text, (2) because it was consistent with the legislative history, and (3) because it was the longstanding construction of the administrative agency. ${ }^{9}$ To be sure, there were also decisions at the polar extremes during this era-either ignoring the agency view or treating it as virtually dispositive. ${ }^{10}$ But in practice, deference existed along a sliding scale, bridging these outer limits.

In addition, in deciding what degree of deference to give an executive interpretation, the Court relied on an eclectic cluster of considerations. ${ }^{11} \mathrm{Al}-$ though there was no explicit rationale linking the various factors together, the overall approach had an implicit logic. The default rule was one of independent judicial judgment. Deference to the agency interpretation was appropriate only if a court could identify some factor or factors that would supply an affirmative justification for giving special weight to the agency views. Admittedly, the factors tended to be invoked unevenly. But in this respect, they probably

7. See Robert A. Anthony, Which Agency Interpretations Should Bind Citizens and the Courts?, 7 YALE J. ON REG. 1, 6 (1990); Monaghan, supra note 6, at 31 .

8. See Batterton v. Francis, 432 U.S. 416,425 n.9 (1977); 5 DAVIS, supra note 6, at 400.

9. For examples of this approach, see Bell v. New Jersey, 461 U.S. 773 (1983); Blum v. Bacon, 457 U.S. 132 (1982); United States v. Clark, 454 U.S. 555 (1982); Federal Election Comm'n v. Democratic Senatorial Campaign Comm'n, 454 U.S. 27 (1981).

10. Compare Newport News Shipbuilding \& Dry Dock Co. v. EEOC, 462 U.S. 669 (1983) (Court discusses EEOC guidelines with no suggestion that they are entitled to deference) with Heckler v. Campbell, 461 U.S. 458, 466 (1983) (Court states that its review is limited to determining whether Secretary's regulations are arbitrary or capricious).

11. For useful accounts of the multiple factors employed during this period, see Colin S. Diver, Statutory Interpretation in the Administrative State, 133 U. PA. L. REV. 549, 562 n.95 (1985); Ernest H. Schopler, Annotation, Supreme Court's View as to Weight and Effect to be Given. on Subsequent Judicial Construction, to Prior Administrative Construction of Statute, 39 L.R.A.2d 942 (1975); David R. Woodward \& Ronald M. Levin, In Defense of Deference: Judicial Review of Agency Action, 31 ADMIN. L. REV. 329, $332-41$ (1979). 
functioned in a manner not too different from the way the canons of interpretation operate in statutory interpretation cases. ${ }^{12}$

The pre-Chevron deference factors may be classified in various ways. For present purposes, I will group them into three categories: (1) factors addressed to Congress' interpretative intent (that is, whether Congress intended courts to defer to an agency's interpretation of a statutory provision); (2) factors addressed to the attributes of the particular agency decision at issue; and (3) factors thought to demonstrate congruence between the outcome reached by the agency and congressional intent regarding that specific issue.

The first factor focused on Congress' probable interpretative intent. The important distinction was between "legislative rules" and "interpretative rules." ${ }^{13}$ Legislative rules were the product of a specific delegation of authority from Congress to an administrative agency to interpret a specific statutory term or fill in a statutory gap. Interpretative rules were executive interpretations not backed by this type of specific delegated authority. The Supreme Court on several occasions suggested that interpretations in the former category were entitled to great deference, but those falling within the latter category were entitled only to whatever persuasive effect they might have. ${ }^{14}$

A second group of factors focused not on the agency's authority, but rather on various attributes of its decision. One factor was whether the issue fell within an area of agency "expertise."15 The idea was that courts are generalists, whereas agencies are specialists. Specialists usually have a better grasp of technical terms ${ }^{16}$ or the practical consequences of a decision, ${ }^{17}$ and thus their views should be given deference by generalists. Another important factor was the notion that "longstanding," "consistent," or "uniform" administrative interpretations (the terms were used more or less interchangeably) are entitled to special deference. ${ }^{18} \mathrm{~A}$ third factor in this category was that interpretations

12. The dominant view for many years, following Llewellyn, was that the canons are mutually contradictory, and hence are of little or no value in guiding judicial decisionmaking. See Karl N. Llewellyn, Remarks on the Theory of Appellate Decision and the Rules or Canons About How Statutes Are to Be Construed, 3 VAND. L. REv. 395, 401-06 (1950). More recently, a revisionist trend has set in, and commentators have begun to take a more sympathetic attitude towand the canons. See CASS R. SUNSTEIN, AFTER THE RIGHTS REVOLUTION: RECONCEIVING THE REGULATORY STATE 111-92 (1990); William N. Eskridge, Jr., Public Values in Statutory Interpretation, 137 U. PA. L. REV. 1007 (1989); Geoffrey P. Miller, Pragmatics and the Maxims of Interpretation, 1990 WIS. L. REV. 1179.

13. See 5 DAVIS, supra note 6, at 421-25; LOUIS JAFFe, JUDICIAL CONTROL OF ADMINISTRATIVE ACTION 564-65 (1965); JAMES M. LANDIS, THE ADMINISTRATIVE PROCESS 146-52 (1938).

14. See, e.g., Heckler v. Campbell, 461 U.S. at 466-68 \& n.10 (deferring to rule promulgated under grant of general rulemaking power); Herweg v. Ray, 455 U.S. 265, 274-75 (1982) (deferring to interpretation with "legislative effect"); Batterton v. Francis, 432 U.S. 416, 424-26 \& nn.8-9 (1977) (distinguishing delegated "legislative power" from nondelegated "interpretative power" and according great deference to agency interpretations using former).

15. See, e.g., Aluminum Co. of Am. v. Central Lincoln Peoples' Util. Dist., 467 U.S. 380,390 (1984).

16. See, e.g., E.I. du Pont de Nemours \& Co. v. Train, 430 U.S. 112, 134-35 \& n.25 (1977).

17. See, e.g., NLRB v. Seven-Up Bottling Co., 344 U.S. 344, 348 (1953); Woodward \& Levin, supra note 11 , at 332 .

18. See United States v. Clark, 454 U.S. 555, 565 (1982); Haig v. Agee, 453 U.S. 280, 291 (1981); NLRB v. Bell Aerospace Co., 416 U.S. 267, 275 (1974); Udall v. Tallman, 380 U.S. 1, 16 (1965). Compare 
supported by a reasoned analysis were entitled to deference. The most prominent statement to this effect is found in Skidmore v. Swift \& Co., ${ }^{19}$ where the Court stated that the weight to be given to an agency interpretation will depend upon "the thoroughness evident in its consideration, the validity of its reasoning, its consistency with earlier and later pronouncements, and all those factors which give it power to persuade, if lacking power to control." ${ }^{20}$ A final decision-related factor, encountered less often, was whether multiple agencies agreed or disagreed about the correct interpretation of the statute. ${ }^{21}$

A third set of factors was designed to measure the degree to which the specific outcome reached by an agency was likely to reflect the intent of Congress. One old idea was that an executive interpretation is entitled to extra weight "when it involves a contemporaneous construction of a statute by the men charged with the responsibility of setting its machinery in motion."22 Contemporaneous interpretations were thought to be especially probative of congressional intent, either because the administrators had themselves participated in the drafting process ${ }^{23}$ or because such an interpretation was "itself evidence of assumptions-perhaps unspoken by either the administrators or Congress-brought to a regulatory problem by all involved in its solution."24 In addition, there was the recurrent notion that executive interpretations are entitled to special deference if they have been ratified in some fashion by Congress. The notion of what would count as a ratification was never very precise. The paradigm situation was when Congress, after being informed of an agency's construction, reenacted a statute without any relevant modification. ${ }^{25}$

Standing alone, these factors did not comprise, either individually or collectively, what could be described as a coherent doctrine. No attempt was made to connect the various factors together or to explain their relevance in terms of a model of executive-judicial relationship. Indeed, my own attempt to organize them in functional categories may impose a greater sense of order than the cases themselves warrant. Moreover, there is little evidence that the factors had much predictive or constraining power. To take but one example,

Nashville Gas Co. v. Satty, 434 U.S. 136, 142 n.4 (1977) (consistently maintained EEOC Guideline given significant weight by Court) with General Elec. Co. v. Gilbert, 429 U.S. 125, $142-43$ (1977) (EEOC Guideline that conflicts with earlier agency interpretation entitled to little weight).

19. 323 U.S. 134 (1944).

20. Id. at 140; see also Adamo Wrecking Co. v. United States, 434 U.S. 275, 287 n.5 (1978) (quoting Skidmore, 323 U.S. at 140); SEC v. Sloan, 436 U.S. 103, 117-18 (1978); Investment Co. Inst. v. Camp, 401 U.S. $617,626-27$ (1971).

21. See North Haven Bd. of Educ. v. Bell, 456 U.S. 512 (1982); General Elec. Co. v. Gilbert, 429 U.S. at 144-45; see also BERNARD SCHWARTZ, ADMINISTRATIVE LAW 664-66 (1984) (discussing a case where federal agencies adopted conflicting positions on whether a particular substance was "oleomargarine").

22. Norwegian Nitrogen Co. v. United States, 288 U.S. 294, 315 (1933).

23. See United States v. Moore, 95 U.S. 760, 763 (1877).

24. SEC v. Sloan, 436 U.S. at 126 (Brennan, J., concurring).

25. See, e.g., NLRB v. Hendricks County Rural Elec. Corp., 454 U.S. 170, 177 (1981); NLRB v. Bell Aerospace Co., 416 U.S. 267, 275 (1974); Red Lion Broadcasting Co. v. FCC, 395 U.S. 367, 381 (1969). 
in $S E C$ v. Sloan $^{26}$ the Securities and Exchange Commission argued that its interpretation not only was entitled to deference because the interpretation was longstanding and consistent but also because it had been ratified by Congress when its construction was cited with approval in a committee report at the time the statute was reenacted. ${ }^{27}$ The Court rejected these arguments, noting that the interpretation was not supported by a careful analysis of the statutory language and that evidence of congressional ratification was not enough if "based only upon a few isolated statements in the thousands of pages of legislative documents."28

As Sloan suggests, application of the various factors in individual cases is manipulable. Still, it would be presumptuous to dismiss them as empty rhetoric. Some factors-such as the importance of longstanding and consistent or contemporaneous administrative constructions-have been invoked as reasons for deferring to executive interpretations for over 150 years. ${ }^{29}$ Given the durability of these factors, it is plausible to view them as reflecting deep-seated judicial intuitions about the kinds of considerations that ought to bear on the decision to defer. If they do not determine the outcome of cases with logical certainty, neither does any other "traditional tool" of statutory interpretation. At least the factors turned the attentions of courts and litigants-including administrators - toward relevant considerations that presumably shape the judicial response.

\section{B. The Chevron Framework}

Chevron was an unlikely candidate to produce a landmark decision on deference to executive interpretations of statutes. The government had not sought a reconsideration of the established approach to judicial review of administrative interpretations, ${ }^{30}$ and only six Justices participated in the decision. Moreover, the disputed issue could be seen as part of the general deregulatory thrust of the early Reagan Administration. In Chevron, the Environmental Protection Agency (EPA) had defined the term "stationary source" in the Clean Air Act to permit owners of polluting facilities to treat all emitting devices as if they were under a single "bubble," thereby minimizing the costs of comply-

26. 436 U.S. 103 (1978).

27. Id. at $117-20$.

28. Id. at 121 .

29. See, e.g., Brown v. United States, 113 U.S. 568, 570-71 (1885) (longstanding and contemporaneous construction); United States v. Moore, 95 U.S. 760, 763 (1877) (contemporaneous construction); Edward's Lessee v. Darby, 25 U.S. (12 Wheat.) 206, 210 (1827) (contemporaneous construction); United States v. Vowell, 9 U.S. (S Cranch) 368, 371 (1809) (longstanding construction); see also Annotation, Effect of Practical or Administrative Construction of a Statuse on Subsequent Judicial Construction, 73 L. Ed. 322 (1929) (citing hundreds of state and federal cases discussing deference to executive views).

30. The United States argued that the "normal rule" of deference should apply, and that the court of appeals was "fundamentally at odds with the most basic principles of administrative law." See Brief for the National Resources Defense Council at 19, Chevron (No. 82-1005). 
ing with the emissions standard. ${ }^{31}$ Just the previous year, in Motor Vehicles Manufacturers Ass'n v. State Farm Mutual, ${ }^{32}$ the Court had reacted with skepticism to a similar deregulatory initiative; thus, it seemed unlikely that the Court would write a broad prodeference opinion in response to the EPA's "bubble policy."

Indeed, there is reason to believe that the participating Justices did not regard Chevron as a departure from prior law. Justice Stevens' opinion for the Court generated no concurring or dissenting statements protesting or even remarking on his approach. And in the year following Chevron, the Court decided nineteen cases involving deference issues, but applied the Chevron framework only once. ${ }^{33}$ In time, however, lower courts, agencies, and commentators all came to regard the analysis of the deference question set forth in Chevron as fundamentally different from that of the previous era. Justice Stevens' opinion contained several features that can only be described as "revolutionary," 34 even if no revolution was intended at the time.

Chevron's first important innovation was the prescription of a procedural formula for courts to follow in determining whether to defer to agency interpretations. Each case, the Court suggested, should proceed in two steps. At step one, the court would operate in the independent judgment mode. It would ask, using traditional tools of statutory construction, whether Congress had "directly spoken to the precise question at issue." 35 If the court concluded that Congress had a "specific intention" 36 with respect to the issue at hand, it would adopt and enforce that answer. But if the court failed to uncover any such intention, it would move on to step two, where it would shift into the deference mode. Here, the question would be whether the agency's position was "a reasonable interpretation" 37 of the statute.

On its face, the two-step formula seems innocuous enough. Indeed, after the formlessness of the previous era, it offers the beguiling promise of an orderly method for resolving a wide variety of controversies. What was unclear at the time, however, was that the two-step inquiry as framed by Chevron

31. 467 U.S. at 840 .

32. 463 U.S. 29 (1983).

33. See Chemical Mfrs. Ass'n v. National Resources Defense Council, 470 U.S. 116 (1985); see also Table 1, infra. Justice Stevens' behavior seems to confirm this point. Early in the next Term, Justice Stevens authored an opinion that was much more consistent with pre-Chevron case law than with the Chevron doctrine. Connecticut Dep't of Income Maintenance v. Heckler, 471 U.S. 524 (1985). And less than three weeks before Chevron was decided, Justice Stevens authored a dissenting opinion stating that no deference was due to an administrative interpretation because it "has not been a model of consistency." Aluminum Co. of Am. v. Central Lincoln People's Util. Dist., 467 U.S. 380, $402-03$ n.3 (1984) (Stevens, J., dissenting). These opinions tend to suggest that Justice Stevens himself regarded Chevron as a restatement of existing law rather than a new approach.

34. Kenneth W. Starr, Judicial Review in the Post-Chevron Era, 3 YALE J. ON REG. 283, 284 (1986). As Judge Starr correctly notes: "This revolutionary effect is not apparent from a quick examination of the opinion itself." Id. at 284.

35. Chevron, 467 U.S. at 842.

36. Id. at 845 .

37. Id. at 844 . 
would have profound consequences for the way in which courts approach the deference question. There are several reasons for reaching this conclusion.

First, in contrast to the previous approach, the two-step structure makes deference an all-or-nothing matter. If the court resolves the question at step one, then it exercises purely independent judgment and gives no consideration to the executive view. If it resolves the question at step two, then it applies a standard of maximum deference. In effect, Chevron transformed a regime that allowed courts to give agencies deference along a sliding scale into a regime with an on/off switch.

Second, the Court's new framework inverted the traditional default rule. In the pre-Chevron period, deference to executive interpretations required special justification; independent judgment was the default rule. Under Chevron, the court must initially establish whether the issue is suitable for independent judicial resolution; if it is not, the court automatically shifts into a deferential mode. As a result, independent judgment now requires special justification, and deference is the default rule. If, as the Court seemed to suggest, the circumstances justifying independent judgment were defined narrowly, this inversion portended a major transfer of interpretative power from courts to agencies.

Third, the two-step framework has important implications for the kinds of considerations that enter into judicial decisionmaking. In particular, the framework appears to exclude any examination of the multiple factors historically relied upon by courts. The most immediate basis for this conclusion is the Court's decision to defer to the EPA's definition of "stationary source" even though it arguably represented a "sharp break with prior interpretations of the Act." ${ }^{38}$ Thus, the decision appeared to downgrade the frequently cited factor stressing the importance of agency views that were longstanding and consistent. ${ }^{39}$ More importantly, none of the traditional factors fits under step one or step two of the new framework. They are clearly irrelevant under step one, which focuses entirely on what happened in Congress, not on the agency or its decision. The factors could conceivably enter into the calculus at step two, where the court asks if the executive interpretation is "reasonable." But by "reasonable," the Court seemed to mean reasonable in light of the text, history, and interpretative conventions that govern the interpretation of a statute by a court; at least, this was the way the Court conducted the reasonableness inquiry in Chevron $^{40}$ and subsequent cases. ${ }^{41}$ The question whether an interpretation

38. Id. at 862 .

39. See Antonin Scalia, Judicial Deference to Administrative Interpretations of Law, 1989 DUKE L.J. 511, 517 (under Chevron, "there is no longer any justification for giving 'special' deference to 'longstanding and consistent' agency interpretations of law"). On the other hand, Chevron itself made passing reference to one traditional factor-agency expertise. See Chevron, 467 U.S. at 865.

40. 467 U.S. at 843-45.

41. See, e.g., Pauley v. Bethenergy Mines, Inc., 111 S. Ct. 2524, 2534-35 (1991); Rust v. Sullivan, 111 S. Ct. 1759, 1769 (1991); United States v. Riverside Bayview Homes, Inc., 474 U.S. 121, 131 (1985). Two decisions from last Term illustrate the problem of what to do with the traditional factors under Chevron. In Pauley, 111 S. Ct. 2524, the Court considered two traditional factors (expertise and longstanding and 
is reasonable in light of these traditional norms of judicial interpretation likewise provides no place for the various contextual factors that played such an important role in the pre-Chevron era.

In addition to its novel framework, Chevron also broke new ground by invoking democratic theory as a basis for requiring deference to executive interpretations. Congress, Justice Stevens reasoned, is the ultimate source of lawmaking authority in a democracy. "If the intent of Congress is clear, that is the end of the matter; for the court, as well as the agency, must give effect to the unambiguously expressed intent of Congress." primary lawgiver are not clear, however, then we are presented with a choice: who should undertake to fill in the gap in the understanding of congressional will, the court or the agency? Chevron declared that the agency is the preferred gap filler. Judges "are not part of either political branch"; they "have no constituency." An agency, on the other hand, while "not directly accountable to the people," is subject to the general oversight and supervision of the President, who is accountable. Thus, it is fitting that agencies, rather than courts, resolve "the competing interests which Congress itself either inadvertently did not resolve, or intentionally left to be resolved by the agency charged with the administration of the statute in light of everyday realities."44

This new emphasis on democratic theory was important to the doctrinal framework because it supplied the justification for switching the default rule from independent judgment to deference. Under the pre-Chevron regime, not every agency decision would qualify for deference in the face of an ambiguous statute. In order to make deference a general default rule, the Court had to come up with some universal reason why administrative interpretations should be preferred to the judgments of Article III courts. Democratic theory supplied the justification: agency decisionmaking is always more democratic than judicial

consistent interpretation) as part of the discussion of whether or not to defer. In Rust, $111 \mathrm{~S}$. Ct. 1759, on the other hand, the Court appended a discussion of traditional factors (lack of consistency in the agency position and the well-reasoned nature of the decision) to its discussion under step two. These recent decisions indicate that the Court continues to believe the traditional factors are relevant, but has no idea what to do with them under the Chevron framework.

42. 467 U.S. at $842-43$.

43. Id. at $865-66$.

44. Id. For a recent elaboration of the democratic theory foundations of Chevron, see Laurence H. Silberman, Chevron-The Intersection of Law \& Policy, 58 GEO. WASH. L. REV. 821, 822-24 (1990). Chevron's democratic theory thesis appears to presuppose a unitary executive, i.e., an interpretation of separation of powers that would place all entities engaged in the execution of the law-including the socalled independent regulatory agencies-under Presidential control. See Steven Calabresi \& Kevin Rhodes, The Structural Constitution: Unitary Executive, Plural Judiciary, 105 HARV. L. REV. (forthcoming Apr. 1992); Geoffrey Miller, Independent Agencies, 1986 SUP. CT. REV. 41. Agencies are not directly accountable to the people; they can invoke a popular mandate only if they are accountable to the elected President. Although the unitary executive construction was dealt a setback in Morrison v. Olson, 487 U.S. 654 (1988) (permitting Congress to insulate independent counsel from removal except for good cause), it is far from clear that the matter has been settled conclusively. See Touby v. United States, 111 S. Ct. 1752, 1757 (1991) (noting that "[t]he Constitution vests all executive power in the President, U.S. Const., Art. II, $\S 1$ 1"). 
decisionmaking because all agencies are accountable (to some degree) to the President, and the President is elected by the people.

Chevron's heavy reliance on democratic theory left one major problem. Congress presumably ranks higher on the democracy scale than do the agencies. After all, Congress is directly elected by the people; agencies are at most indirectly accountable to the electorate through the President. Yet how do we know that Congress, the ultimate democratic trump card, wants ambiguities and gaps to be resolved by agencies rather than by courts?

Chevron solved this potential quandary by adopting its third and probably most controversial innovation: a presumption that whenever Congress has delegated authority to an agency to administer a statute, it has also delegated authority to the agency to interpret any ambiguities present in the statute..$^{45}$ Previous cases, as we have seen, suggested that deference was appropriate if Congress had expressly delegated to an executive agency the power to define a particular term. Chevron in effect adopted a fiction that assimilated all cases involving statutory ambiguities or gaps into the express delegation or "legislative rule" model. ${ }^{46}$

In short, the Chevron opinion can be understood as a prescription for resolving questions of statutory interpretation through a series of presumptions about primary and delegated lawmaking. Congress is presumed to be the primary lawmaking institution, and where it has spoken, its will must prevail. But when Congress has not addressed the precise issue in dispute and has delegated authority to an administrative agency, then we presume that interpretative authority has been delegated to the agency. Only if Congress is silent and has failed to designate an agency to administer the statute do we presume that power to interpret ambiguous law has been delegated to an Article III court.

Given the rhetoric of Justice Stevens' opinion, the most apparent objective of this series of presumptions was to maximize the role of democratically accountable institutions in the process of legal interpretation and to restrict the discretion of unelected courts. Conceivably, the formalism of Chevron may also

45. In Chevron, the Court stated the presumption in terms of "implicit" delegations:

'The power of an administrative agency to administer a congressionally created ... program necessarily requires the formulation of policy and the making of rules to fill any gap left, implicitly or explicitly, by Congress.' If Congress has explicitly left a gap for the agency to fill, there is an express delegation of authority to the agency to elucidate a specific provision of the statute by regulation. ... Sometimes the legislative delegation to an agency on a particular question is implicit rather than explicit.

467 U.S. at $843-44$ (quoting Morton v. Ruiz, 415 U.S. 199, 231 (1974)).

Recent decisions have reaffirmed that the general duty to defer identified in Chevron is grounded in a theory of presumed delegation. See Pauley, 111 S. Ct. at 2534; Martin v. Occupational Safety \& Health Review Comm., 111 S. Ct. 1171, 1175 (1991) (discussing deference to an agency's interpretation of its own regulations); Adams Fruit Co. v. Barrett, 110 S. Ct. 1384 (1990). For an especially clear recognition that Chewron rests on a presumption that ambiguities entail a delegation of interpretative power, see Scalia, supra note 39 , at 516-17.

46. See Kevin W. Saunders, Interpretative Rules with Legislative Effect: An Analysis and a Proposal for Public Participation, 1986 DuKE L.J. 346, 357 (Chevron appears to eliminate the distinction between legislative rules and intepretative rules). 
have reflected a desire to streamline the deference inquiry by reducing the multiple variables of the preceding era to two basic inquiries. In any event, in the clarity of its procedural formula, and the implications of that formula for the balance of power among the branches, Chevron does indeed appear to presage a "revolutionary" transformation of the old order.

\section{Chevron: The Revolution in Practice}

Each year the Supreme Court decides somewhere between ten and twenty cases in which it confronts an issue about whether to defer to an administrative interpretation of a statute. This steady stream of deference cases has abated only slightly since Chevron was decided. As a result, there is now an extensive body of decisional law within the Court that can be used to gauge Chevron's impact. Surprisingly, no one has undertaken a comprehensive survey of these decisions. ${ }^{47}$ To the contrary, the commentary on Chevron tends to assume-almost always based on only a handful of the Court's post-Chevron decisions-either that the Court has faithfully followed Chevron in succeeding years ${ }^{48}$ or that the Court has essentially disregarded the radical implications of the decision. ${ }^{49}$

A survey of the full range of the Court's decisions before and after Chevron discloses a more complex and indeed rather bewildering picture. On the one hand, Chevron clearly has resulted in a significant shift in the deference doctrine. On the other hand, Chevron has not produced anything like a complete revolution in the Court's jurisprudence. On the whole, the overall picture suggests that the judicial understanding that informs the deference question is probably more confused today than it has ever been.

\section{A. The Incomplete Revolution}

One way to measure the impact of Chevron is to examine the Court's own post-Chevron deference cases in the aggregate. In order to make such an assessment, I reviewed all Supreme Court decisions from the 1981 Term to the end of the 1990 Term. The results for the seven post-Chevron Terms (Chevron was decided near the end of the $1983 \mathrm{Term}$ ) are summarized in Table $1 .{ }^{50}$

47. The most complete account of post-Chevron developments in the Supreme Court is found in Sunstein, supra note 4, at 2091-104.

48. See, e.g., Richard J. Pierce, Jr., Chevron and its Aftermath: Judicial Review of Agency Interpretations of Statutory Provisions, 41 VAND. L. REV. 301, 302 (1988); Starr, supra note 34, at 291.

49. See, e.g., Linda R. Hirschman, Postmodern Jurisprudence and the Problem of Administrative Discretion, 82 NW. U. L. REV. 646, 703 (1988).

50. The cases that comprise the data are summarized in the tables, infra pp. 981-82, 992, and are listed in the Appendix, infra. 
TABLE 1. Post-Chevron Terms

\begin{tabular}{|c|c|c|c|c|c|c|}
\hline \multirow[b]{2}{*}{ TERM } & A & B & C & D & $E$ & $\mathbf{F}$ \\
\hline & $\begin{array}{c}\text { TOTAL CASES } \\
\text { INYOLVING } \\
\text { DEFERENCE } \\
\text { QUESTION }\end{array}$ & $\begin{array}{l}\text { AGENCY VEW } \\
\text { ACCEPTED }\end{array}$ & $\begin{array}{c}\text { CHEVRON } \\
\text { FRAMEWORK } \\
\text { APPLIED }\end{array}$ & $\begin{array}{c}\text { CHEVRON } \\
\text { FRAMEWORK: } \\
\text { AGENCY VIEW } \\
\text { ACCEPTED }\end{array}$ & $\begin{array}{c}\text { CHEVRON } \\
\text { FRAMEWORK: } \\
\text { DECIDED AT } \\
\text { STEP TWO }\end{array}$ & $\begin{array}{c}\text { CASES CTIING } \\
\text { TraDmIONAL } \\
\text { Factors }\end{array}$ \\
\hline 1990 & 11 & $8(73 \%)$ & $6(55 \%)$ & $4(66 \%)$ & $2(33 \%)$ & $6(55 \%)$ \\
\hline 1989 & 14 & $8(57 \%)$ & $9(62 \%)$ & $4(44 \%)$ & $2(25 \%)$ & $4(29 \%)$ \\
\hline 1988 & 9 & $4(44 \%)$ & $3(33 \%)$ & $1(33 \%)$ & $1(33 \%)$ & $6(66 \%)$ \\
\hline 1987 & 14 & $9(64 \%)$ & $5(36 \%)$ & $3(60 \%)$ & $3(50 \%)$ & $3(21 \%)$ \\
\hline 1986 & 9 & $5(55 \%)$ & $2(22 \%)$ & $1(50 \%)$ & $1(50 \%)$ & $2(22 \%)$ \\
\hline 1985 & 14 & $11(78 \%)$ & $6(43 \%)$ & $5(83 \%)$ & $4(66 \%)$ & $6(43 \%)$ \\
\hline 1984 & 19 & $18(94 \%)$ & $1(5 \%)$ & $1(100 \%)$ & $1(100 \%)$ & 7 (35\%) \\
\hline 1984 & 90 & $63(70 \%)$ & $32(36 \%)$ & $19(59 \%)$ & $14(44 \%)$ & $34(37 \%)$ \\
\hline
\end{tabular}

Column A reports the total number of cases each Term in which at least one Justice recognized the presence of a question (concerning either a primary or a subsidiary issue) about whether to give deference to an administrative interpretation of a statute. ${ }^{51}$ Column $B$ indicates how many of these decisions accepted the executive interpretation. ${ }^{52}$ Column $\mathrm{C}$ shows how many of the total cases applied the two-step Chevron framework or its equivalent; ${ }^{53}$ column

51. Adopting a principle for including cases in the survey posed some problems. On the one hand, it is commonly perceived that there are many cases in which the Court substitutes its judgment for that of the agency and fails even to mention the possibility of deference. See 5 DAVIS, supra note 6 , at 403 . Ideally, these cases would be included in the sample in order to determine the true incidence of deference. On the other hand, it would be very difficult to determine all the cases in which the Court could have deferred. I would have had to read the briefs and records in all cases involving a question of federal statutory interpretation. Moreover, determining the full set of potential deference cases based on some independent standard would pose difficult conceptual problems in defining what is a potential deference case. For instance, would a decision count as a potential deference case if it involved an interpretation adopted for the first time in briefs filed in court defending an agency action? Would a decision count as a potential deference case if it involved an interpretation of a provision that the agency is not directly empowered to regulate? Given these competing considerations, I compromised and adopted a selection principle that included all cases in which at least one Justice mentioned the possibility of deferring to an agency interpretation. This picks up some of the cases where the majority substitutes judgment and does not mention deference, but a dissenting or concurring Justice raises the issue. Thus, it produces a slightly larger sample than would an approach that looked solely to majority opinions. But clearly the one-Justice principle does not include all potential deference cases (for example, it skips cases where the Court is unanimous and substitutes its judgment). Consequently, the sample still undercounts the total number of cases where deference could have been invoked.

Another problem was what to do with cases that present slight variations on the question of deference to agency interpretations of statutes, such as cases involving an agency interpretation of its own regulations, agency interpretations of a treaty, or challenges to agency policies on the ground that they were adopted in an arbitrary and capricious manner (as opposed to being in conflict with a statute). These cases (which were relatively few in number compared to the statutory interpretation cases) were excluded in the interest of minimizing complexity.

52. "Accepting the agency interpretation" is not the same as ruling in favor of the government. In a few cases the Court ruled against the government even though it accepted the agency interpretation. This might happen, for example, if the Solicitor General disclaimed the agency view, but the Court agreed with it. See, e.g., Bob Jones Univ. v. United States, 461 U.S. 574 (1983).

53. I adopted a very broad test for determining whether the Court was "applying" the Chevron framework. I included in this category not just the cases that quoted the two-step procedure, or organized the discussion around the two-step procedure, but also those that cited Chevron or post-Chevron decisions, 
D reports how many of the cases following the Chevron framework accepted the executive interpretation; column $E$ reveals the number of Chevron cases that gave some consideration to the reasonableness of the executive view (step two of the framework) as opposed to stopping at step one. Finally, column $\mathrm{F}$ indicates how many controlling opinions in the cases rely on one or more of the traditional factors applied in the pre-Chevron period, such as longstanding and consistent interpretation, contemporaneous interpretation, congressional ratification, and so forth. ${ }^{54}$ In order to provide a basis for comparison, Table 2 reproduces data for some of these variables (total deference cases, cases accepting the administrative interpretation, and cases applying traditional factors) for the three pre-Chevron Terms, 1981-83.

TABLE 2. Pre-Chevron Terms

\begin{tabular}{cccc}
\hline & A & B & F \\
TERM & $\begin{array}{c}\text { TOTAL CASES INVOLVING } \\
\text { DeFERENCE QUESTION }\end{array}$ & AGENCT VIEW ACCEPTED & $\begin{array}{c}\text { CASES CTING } \\
\text { TRADTIONAL FACTORS }\end{array}$ \\
\hline 1983 & 19 & $13(68 \%)$ & $11(57 \%)$ \\
1982 & 15 & $11(73 \%)$ & $11(73 \%)$ \\
1981 & 11 & $10(90 \%)$ & $8(73 \%)$ \\
\hline TOTAL $1981-83$ & 45 & $34(75 \%)$ & $30(66 \%)$
\end{tabular}

A number of interesting conclusions can be derived from the figures in Tables 1 and 2. First, it is clear that Chevron is often ignored by the Supreme Court. Although the Chevron opinion purports to describe a universal standard by which to determine whether to follow an administrative interpretation of a statute, the two-step framework has been used in only about one-third of the total post-Chevron cases in which one or more Justices recognized that a deference question was presented. ${ }^{55}$ Although Chevron began to be used more frequently after the $1987 \mathrm{Term}$, it is still far from the monolithic norm the

such as K Mart Corp. v. Cartier, Inc., 486 U.S. 281 (1988), in setting forth the standard of review, or that otherwise indicated that deference would be owed to any agency decision provided Congress had not clearly answered the question. Essentially, I tried to determine whether the author of the controlling opinion was thinking about Chevron in setting forth the analysis of deference. Although admittedly this is a highly subjective standard, I believe it is more reliable than any other yardstick. If anything, it tends to overstate the influence of Chevron.

54. Column $F$ includes both Chevron framework cases and non-Chevron framework cases. Most of the cases in this column either ignore or disclaim reliance on Chevron in favor of the traditional approach. Some, however, purport to rely on the Chevron framework, even if this is (arguably) inconsistent with also relying on the traditional factors.

55. This undoubtedly understates the extent to which Chevron is ignored, because cases where there is an executive interpretation, but where the Court fails to note even the possibility of deferring to that interpretation, were excluded from the survey. In other words, the most extreme instances of "independent judgment" were ignored. See supra note 51 . 
opinion seems to describe. If we look solely at the $1987-90$ period, the two-step framework was still applied in only half of the deference decisions.

Although some of the failure to rely on Chevron may be attributed to time lag, as awareness of the decision slowly disseminated through the administrative bar, ${ }^{56}$ this cannot account for the persistent resistance to using the framework in the Supreme Court. By the end of the 1987 Term, for example, the Court had applied the Chevron framework in fifteen different cases in a wide variety of areas. ${ }^{57}$ Any Justice who was paying attention to the Court's own work product should have been thoroughly versed in the tenets of Chevron by this time. Moreover, even if administrative lawyers in specialized areas like tax and labor law were late in coming to an awareness of Chevron, the federal agencies were represented in the Supreme Court almost exclusively by the Solicitor General's office-a small group of "generalists" who have been very conscious of Chevron.$^{58}$ Thus, by 1987 at the latest, the agencies could be expected to take maximum advantage of Chevron in the Supreme Court. Yet in the 1988-90 Terms, the Court continued to apply the Chevron framework in only half the cases presenting a deference question. The persistent spottiness of Chevron during this period strongly suggests that the Court in many cases was simply

56. The survey clearly suggests such a time lag. As previously noted, it took some time for the Chevron doctrine to appear in the Court's opinions; the 1984 Term must for all intents and purposes be considered part of the pre-Chevron era. Moreover, even in years when Chevron is applied with some frequency, it tends to be invoked less often in areas where there is a particularly rich tradition of pre-Chevron precedent on deference. For example, in Title VII, labor, tax, social security, and environmental cases, the Court (no doubt guided to a degree by the submissions of the parties) still tends to frame the deference standard in the terms expressed in earlier decisions specific to these areas, rather than in terms of Chevron. See, e.g., Cottage Sav. Ass'n v. Commissioner, 111 S. Ct. 1503 (1991) (citing previous cases for deference standard; no mention of Chevron); EEOC v. Arabian Am. Oil Co., 111 S. Ct. 1227, 1235 (1991) (citing pre-Chevron cases for standard of deference to EEOC); Robertson v. Methow Valley Citizens Council, 490 U.S. 332 (1989) (Council on Environmental Quality's interpretation of NEPA assessed under traditional factors, no citation to Chevron); Atkins v. Rivera, 477 U.S. 154 (1986) (review of Social Security Administration interpretation based on legislative/interpretative distinction of pre-Chevron era); Meritor Sav. Bank v. Vinson, 477 U.S. 57, 65 (1986) (same); NLRB v. Action Automotive, Inc., 469 U.S. 490, 494-96 (1984) (citing Packard Motor Car Co. v. NLRB, 330 U.S. 485 (1947), and NLRB v. Hearst Publications, Inc., 332 U.S. 111 (1944) (deference appronch to NLRB decisions).

In contrast, in areas in which the pre-Chevron case law was less well developed-ERISA and banking cases seem to fall in this category-Chevron seems to have made more headway in the Court. See, e.g., Pension Benefit Guar. Corp. v. LTV Corp., 110 S. Ct. 2668, 2676 (1990) (applying Chevron standard in ERISA controversy); Mead Corp. v. Tilley, 490 U.S. 714 (1989) (same); Clarke v. Securities Indus. Ass'n, 479 U.S. 388 (1987) (Chevron applied to interpretation by Comptroller of Currency); Board of Governors v. Dimension Fin. Corp., 474 U.S. 361 (1986) (Chevron framework applied to Federal Reserve interpretation).

57. K Mart Corp. v. Cartier, Inc., 486 U.S. 281 (1988); Edward J. DeBartolo Corp. v. Florida Gulf Coast Bldg. \& Constr. Trades Council, 485 U.S. 568 (1988); Bethesda Hosp. Ass'n v. Bowen, 485 U.S. 399 (1988); ETSI Pipeline Project v. Missouri, 484 U.S. 495 (1988); Honig v. Doe, 484 U.S. 305 (1988); NLRB v. United Food \& Commercial Workers Union, Local 23, 484 U.S. 112 (1987); INS v. Cardoza-Fonseca, 480 U.S. 421 (1987); Clarke v. Securities Indus. Ass'n, 479 U.S. 388 (1987); Japan Whaling Ass'n v. American Cetacean Soc'y, 478 U.S. 221 (1986); United States Dep't of Transp. v. Paralyzed Veterans of Am., 477 U.S. 597 (1986); Young v. Community Nutrition Inst., 476 U.S. 974 (1986); United States v. City of Fulton, 475 U.S. 657 (1986); Board of Governors v. Dimension Fin. Corp., 474 U.S. 361 (1986); United States v. Riverside Bayview Homes, Inc., 474 U.S. 121 (1985); Chemical Mfrs. Ass'n v. National Resources Defense Council, 470 U.S. 116 (1985).

58. This was true by the fall of 1987, when I joined the Solicitor General's Office. 
not prepared to abide by the type of analysis dictated by Chevron-although apparently it was not prepared to abandon it or explain why it ought not to be controlling either.

Second, although Chevron is generally regarded as directing that courts give greater deference to executive interpretations, there is no discernible relationship between the application of the Chevron framework and greater acceptance of the executive view. Indeed, cases applying the Chevron approach have on the whole produced fewer affirmances of executive interpretations than those that do not follow Chevron. ${ }^{59}$ Although the number of cases is too small to attribute significance to the precise percentages, the general phenomenon is apparent when we compare the rate of acceptances in the cases actually applying the Chevron framework in the post-Chevron period-59\% adopting the agency view-with either the overall acceptance rate in the post-Chevron period (70\%) or the rate in the pre-Chevron era (75\%). Paradoxically, it appears that adoption of the Chevron framework has meant, if anything, a decline in deference to agency views.

The suggestion that Chevron has had little discernible influence on the Supreme Court contrasts sharply with the only other published empirical study of Chevron's impact. Professors Peter Schuck and Donald Elliot undertook a survey of Chevron's influence on lower courts and found that deference to agency interpretations increased sharply after Chevron..$^{60}$ Their findings, however, are not necessarily inconsistent with my data suggesting no such change in the Supreme Court. Lower courts probably take Supreme Court opinions more seriously than does the Court itself. ${ }^{61}$ Moreover, one would predict that as it became increasingly evident over time that the Supreme Court employs the Chevron approach only sporadically, lower courts would begin to revert to their old habits. And indeed, there is evidence in the Schuck and Elliot study that suggests the "Chevron effect" in the lower courts may have been only temporary. ${ }^{62}$

Third, the tables indicate that the emergence of Chevron has caused a decline in reliance on the traditional contextual factors for determining whether

59. This conclusion is to some extent probably a reflection of my sampling methodology. In particular, the non-Chevron cases may contain a disproportionate number of affirmances. This is because when the Court agrees with an agency construction, it may often throw in deference to the administrative agency as an additional factor or consideration in support of its judgment. But when it disagrees with the agency view, it may not mention the issue of deference. On the other hand, this possibility is mitigated by the fact that even if the majority ignores the agency interpretation, a dissenting or concurring opinion may raise the issue of deference-and these cases are also included in the sample. Moreover, even if the rate of agency affirmances is overstated in the non-Chevron cases, this would not account for the relatively low percentage of affirmances in the cases applying the Chevron framework, where the issue of deference is necessarily presented in each instance.

60. Peter H. Schuck \& E. Donald Elliott, To the Chevron Station: An Empirical Study of Federal Administrative Law, 1990 DUKE L.J. 984.

61. Indeed, they are required to do so in many circumstances. See Hicks v. Miranda, 422 U.S. 332, 343-45 (1975) (lower courts bound by Supreme Court summary affirmance, even if Court itself is not).

62. Schuck \& Elliott, supra note 60, at 1037. 
deference is appropriate. Again, the numbers are too small to attribute significance to precise percentages, but in the pre-Chevron period (1981-83 Terms) $66 \%$ of the deference cases cited one or more of these traditional factors. In the post-Chevron period, in contrast, the percentage of cases citing one of these factors declined to $36 \%$ overall. Still, it is obvious that the Court's invocation of these factors persists, with no visible trend pointing toward their complete extinction. This is not what one would expect to find if Chevron had completely transformed the practice of deciding when to defer.

\section{B. The Contested Revolution}

When we turn from the aggregate data to an examination of the Court's opinions, the picture that emerges again suggests that the Chevron revolution-although real-is a tenuous one. I will not discuss the many routine applications of Chevron, the even more numerous cases that ignore Chevron, or even those cases where the majority and dissent disagree over the proper application of Chevron to particular circumstances. More revealing are the opinions that engage in disputes over what might be called "Chevron fundamentals." The presence of these disputes is not necessarily surprising. There has probably never been a watershed Supreme Court opinion (consider Brown, Miranda, Mapp, and Roe $)^{63}$ that did not generate subsequent controversy over the scope and meaning of the original decision. What is striking, however, is the extent to which the Court's resolutions of disputes over the meaning of the Chevron framework rest uncomfortably with the rationale of the original decision.

Without a doubt, the most remarkable episode occurred in INS $v$. Cardoza-Fonseca ${ }^{64}$ a case involving interpretation of immigration law, where the Court has traditionally shown considerable deference to executive views. ${ }^{65}$ Specifically, the issue was whether the statutory standard for awarding asylum could be construed as requiring the same showing of likelihood of persecution upon return to the country of origin as the standard for withholding of deportation. The Attorney General, acting through the Bureau of Immigration Appeals, determined that the two provisions required the same showing. A bare majority of five Justices-in an opinion by Justice Stevens, the author of Chevron - held that this executive interpretation was not entitled to deference. The first reason was entirely consistent with the Chevron framework: "Employing traditional tools of statutory construction, we have concluded that Congress did not intend

63. Brown v. Board of Educ., 347 U.S. 483 (1954); Miranda v. Arizona, 384 U.S. 436 (1966); Mapp v. Ohio, 367 U.S. 643 (1961); Roe v. Wade, 410 U.S. 113 (1973).

64. 480 U.S. 421 (1987).

65. See, e.g., INS v. Rios-Pineda, 471 U.S. 444, 452 (1985) (admonishing lower courts not to usurp authority granted to the Attorney General in administering the immigration laws); Hampton v. Mow Sun Wong, 426 U.S. 88, 101-02 n.21 (1976) (noting that "power over aliens is of a political character and therefore subject to only a narrow judicial review"). 
the two standards to be identical." ${ }^{\prime 66}$ In what appeared to be an alternative holding, however, Justice Stevens stated that the Chevron standard was in any event inapplicable because the issue for decision was a "pure question of statutory construction." ${ }^{37}$ Deference would be appropriate, he suggested, only if the case concerned the application of the standard to particular facts. ${ }^{68}$

The notion that deference to agency views should turn on the distinction between pure questions of law and questions of law application can be found in some Supreme Court decisions of the 1940's. ${ }^{69}$ But the distinction had been abandoned for all practical purposes long before Chevron was decided. ${ }^{70}$ The suggestion that what Chevron had done was to restore this ancient learning was truly astonishing, as Justice Scalia made clear in an acidic concurrence. In fact, as Justice Scalia correctly noted, the issue in Chevron, concerning the proper definition of the statutory term "source," was obviously a "pure question of law," and hence would be entitled to no deference under the Court's distinction. ${ }^{71}$ Moreover, the dispute about the proper meaning of Chevron had not been briefed and argued in Cardoza-Fonseca, nor was it necessary to the decision. It was thus inappropriate for the Court to cast doubt on such "an extremely important and frequently cited opinion." 72

Cardoza-Fonseca gave rise to a brief period of uncertainty in the lower courts over whether Chevron still applied to pure questions of law. ${ }^{73}$ By the end of the next Term, however, the Court was again applying the Chevron doctrine (irregularly, as ever) to questions of law, and Cardoza-Fonseca quietly dropped from sight. ${ }^{74}$ But if Cardoza-Fonseca had no lasting impact on the

66. Cardoza-Fonseca, 480 U.S. at 446.

67. Id.

68. Id. at 448 .

69. Compare Packard Motor Car Co. v. NLRB, 330 U.S. 485, 493 (1947) (no deference to agency views on "naked question of law") with NLRB v. Hearst Publications, Inc., 322 U.S. 111, 130-31 (1944) (great deference to NLRB's determination of how statutory standard applied to particular factual circumstances).

70. See, e.g., Federal Election Comm'n v. Democratic Senatorial Campaign Comm., 454 U.S. 27 (1981) (deferring to agency interpretation of pure question of law); Ford Motor Credit Co. v. Milhoilin, 444 U.S. 555 (1980) (same); Monaghan, supra note 6, at 29-30.

71. Cardoza-Fonseca, 480 U.S. at 455 (Scalia, J., concurring in judgment).

72. Id. at 454 (Scalia, J., concurring in judgment).

73. See NLRB v. Federal Labor Relations Auth., 834 F.2d 191, 198 (D.C. Cir. 1987) (under Cardoza-Fonseca no deference due to agency interpretation of "pure question of law"); Union of Concerned Scientists v. United States Nuclear Regulatory Comm'n, 824 F.2d 108, 113 (D.C. Cir. 1987) (Cardoza-Fonseca "strongly indicate[s] that courts are to apply the Chevron test only in circumstances in which an agency is required to apply a legal standard to a particular set of facts"). But see NLRB v. FLRA, 834 F.2d at 202 (Starr, J., concurring) ("I continue to believe that Chevron's two-step interpretative process, which was reaffirmed in Cardoza-Fonseca, provides the polestar that is to guide us."); id. at 203 (D. Ginsburg, J., concurring) (sharing Judge Starr's belief).

74. Early in the next term, Justice Scalia stated in a concurring opinion, NLRB v. United Food \& Commercial Workers Union, Local 23, 484 U.S. 112, 133-34 (1987) (Scalia, J., concurring), that CardozaFonseca was not being followed by the Court (although the majority in that case cited both Chevron and Cardoza-Fonseca). Shortly thereafter, the Court reverted to the Chevron framework without any suggestion that it was confined to cases of law application. See Mead Corp. v. Tilly, 490 U.S. 714 (1989); Pittston CoaI Group v. Sebben, 488 U.S. 105 (1988); K Mart Corp v. Cartier, Inc., 486 U.S. 281 (1988). 
Court's understanding of the Chevron doctrine, the episode nevertheless suggests that the Court's commitment to Chevron-at least in its unvarnished original form-was at best fragile. The fact that a majority of the Court was prepared (if only temporarily) to recast that doctrine in a way that would strip it of most of its significance hardly suggests that the Court was comfortable with Chevron's innovations.

Other disputes over Chevron fundamentals soon followed. Although less dramatic than Cardoza-Fonseca, on balance they too suggested that the Court was not prepared to accept the full implications of the decision.

With respect to one issue-what type of agency decision is entitled to Chevron deference- the Court has been faithful to Chevron's logic. In Adams Fruit Co. $v$. Barrett, ${ }^{75}$ the Court held that Chevron applies only to agency decisions that are an exercise of delegated authority. Thus, a statement by the Department of Labor about the scope of private judicial remedies available under a federal statute was entitled to no deference because the agency was given no authority to regulate this matter. Although this decision cuts back on the potential scope of the Chevron doctrine, it is consistent with the language and rationale of Chevron, with its focus on the delegation of interpretative authority implicit in the delegation of decisional authority.

With respect to other issues, however, the Court has departed from Chevron's logic. For example, the Court has held that Chevron deference does not apply to legal interpretations advanced for the first time in appellate briefs filed on behalf of an agency. ${ }^{76}$ This conclusion is consistent with established tenets of administrative law. ${ }^{77}$ But unlike the proposition recognized in Adams Fruit, a general "post hoc rationalization of counsel" exception is not consistent with Chevron. If Congress has delegated authority to an agency to enforce a particular statute, and therefore (per Chevron) has impliedly delegated interpretative authority to the agency, it should not matter if the agency announces its interpretation through a brief as opposed to, for example, an opinion letter written by the general counsel or an informal adjudication (both of which have been held to be entitled to Chevron deference ${ }^{78}$ ). Indeed, Justice Scalia has recognized in a law review article that the "post hoc rationalization" of counsel exception is at odds with Chevron. ${ }^{79}$ Whatever the implications of Chevron

75. 494 U.S. 638 (1990). The holding in Adams Fruit was foreshadowed by Justice Scalia's concurring opinion in Crandon v. United States, 494 U.S. 152, 168-84 (1990), where he argued that legal opinions of the Office of Legal Counsel of the Department of Justice were not entitled to Chevron deference because they dealt with matters over which that office had no enforcement responsibility.

76. Bowen v. Georgetown Univ. Hosp., 488 U.S. 204, 212 (1988).

77. See SEC v. Sloan, 436 U.S. 103, 117-18 (1978); Investment Co. Inst. v. Camp, 401 U.S. 617, 628 (1971); SEC v. Chenery Corp., 318 U.S. 80 (1943).

78. See Pension Benefit Guar. Corp. v. LTV Corp., 110 S. Ct. 2668 (1990) (Chevron deference to prior opinion letters); Mead Corp. v. Tilley, 490 U.S. 714 (1989) (same); Japan Whaling Ass'n v. American Cetacean Soc'y, 478 U.S. 221 (1980) (Chevron deference to Commerce Department certification of national compliance with treaty obligations); Young v. Community Nutrition Inst., 476 U.S. 974 (1986) (Chevron deference to FDA notices setting "tolerance levels").

79. Scalia, supra note 39 , at 517-18. 
might be for this issue, however, it is clear that the Court is not about to start deferring to government legal briefs.

Another issue that has resulted in a potentially important qualification of the Chevron framework concerns the status of canons of statutory construction. Chevron itself does not mention canons, and it is unclear where they fit under the framework. Although the canons clearly qualify as a "traditional too[l] of statutory construction," ${ }^{80}$ it is odd to think of a court concluding on the basis of a canon that Congress had an intention "on the precise question at issue." Canons are maxims or rules of thumb that allow courts to impute answers to interpretative questions when it is not possible to discern by more direct means what the legislature intended. Thus, one would expect that if a court could interpret a statute only by invoking a canon, it would be forced to acknowledge that the issue is one to which Congress has not clearly spoken and that, under Chevron, it must therefore defer to a reasonable interpretation by the administrative agency. Conceivably, the court would consider the canons at step two, in asking whether the agency interpretation is reasonable. ${ }^{81}$ But again, if an agency interpretation is consistent with the language and purpose of a statute, it is hard to see how it could be condemned as unreasonable simply because a judicial canon would suggest a contrary result.

The Court first directly confronted the issue of canons and Chevron in Edward J. DeBartolo Corp. v. Florida Gulf Coast Building \& Construction Trades Council. ${ }^{82}$ The Court acknowledged that the relevant provision of the National Labor Relations Act was ambiguous and that the National Labor Relations Board (NLRB) had interpreted the provision to prohibit certain types of handbilling. But the Court also thought the NLRB's construction would raise serious constitutional questions. Relying on the canon of avoiding interpretations that raise serious constitutional questions, ${ }^{83}$ the Court in effect held that the result suggested by Chevron was trumped by the result suggested by the canon. Thus, instead of integrating the canon into step one-on the ground that it was indicative of congressional intent-or step two-on the ground that it illuminated the question of reasonableness- the Court used the canon to oust the Chevron framework altogether.

The implications of this decision for the future of Chevron are hard to assess. On the one hand, DeBartolo could mean that Chevron itself is just another canon, as Professor Cass Sunstein has argued. ${ }^{84}$ If true, this would raise a whole host of unanswered-and probably unanswerable-questions about which canons override Chevron and which are subordinate to Chevron.

80. Chevron U.S.A., Inc. v. National Resources Defense Council, 467 U.S. 837, 843 n.9 (1984).

81. Cf. Note, Chevron and Canons of Statutory Construction, 58 GEO. WASH. L. REV, 829 (1990) (arguing that "statute defining" canons should apply at step one while "statute applying" canons should apply at step two).

82. 485 U.S. 568 (1988).

83. See NLRB v. Catholic Bishop, 440 U.S. 490 (1979).

84. Sunstein, supra note 4 , at 2113. 
On the other hand, in Rust v. Sullivan, ${ }^{85}$ the Court applied Chevron and refused to follow DeBartolo in circumstances where three Justices found that the agency interpretation was unconstitutional, ${ }^{86}$ thus establishing that it raised "serious constitutional doubts." Rust could mean that DeBartolo will be confined to its facts. ${ }^{87}$ In any event, in holding that at least one canon trumps Chevron on at least one occasion, the Court has further called into doubt its commitment to the strictures of the Chevron doctrine..$^{88}$

A third development concerns agency interpretations that are at odds with prior judicial precedent. Chevron holds that statutory ambiguities are to be resolved, if possible, by agencies not courts. Thus, if a court has construed an ambiguous statute one way (without the benefit of an agency view), and an agency later has occasion to read the statute differently, the logic of Chevron would seem to indicate that the court should follow the agency interpretation, rather than the earlier judicial pronouncement. Indeed, the D.C. Circuit in Chevron had invalidated the EPA's interpretation of "stationary source" largely because it was contrary to prior D.C. Circuit precedent, and the Court held that this did not justify a departure from deference. ${ }^{89}$

Nevertheless, the Supreme Court, in Maislin Industries, U.S. v. Primary Steel, Inc. ${ }^{90}$ emphatically rejected the idea that an agency might disregard a previous judicial construction of a statute, at least when it is a precedent of the Supreme Court: "Once we have determined a statute's clear meaning, we adhere to that determination under the doctrine of stare decisis, and we judge an agency's later interpretation of the statute against our prior determination of the statute's meaning." 11 It is difficult to quarrel with this conclusion, for there would be something unsettling about a world in which executive branch administrators could "overrule" Supreme Court decisions. Again, however, the

85. 111 S. Ct. 1759 (1991).

86. See id. at 1780-86 (Blackmun, J., dissenting, joined by Marshall \& Stevens, JJ.).

87. Chief Justice Rehnquist's opinion for the majority was less than illuminating on the question of why the constitutional issues did not raise a "serious question." He simply stated that petitioners' constitutional arguments, although "not without some force," were not enough to "carry the day." Id. at 1771. The opinion arguably can be read as limiting the DeBartolo canon to cases in which the agency interpretation would be unconstitutional, as opposed to merely raising a "serious question" of constitutionality.

88. Other cases have presented questions involving the interaction of Chevron and the canons, but have not shed much light on the issue. In EEOC v. Arabian Am. Oil Co., 111 S. Ct. 1227, 1230 (1991), the Court relied heavily on the canon that statutes are presumed not to apply outside the territorial limits of the United States, and refused to defer to the contrary judgment of the EEOC. But the Court did not apply the Chevron framework, so the decision does not say anything about the relationship between Chevron and the canons. In Michigan Citizens for an Indep. Press v. Thornburgh, 868 F.2d 1285, 1292-93 (D.C. Cir. 1989), aff'd, 493 U.S. 38 (1989), the D.C. Circuit reasoned that Chevron supersedes canons based on substantive policy considerations, such as the canon requiring that exceptions to the antitrust laws be narrowly construed. The Court granted certiorari but affirmed by an equally divided vote, and thus wrote no opinion.

89. Chevron U.S.A., Inc. v. National Resources Defense Council, 467 U.S. 837, 841-42 (1984); see also Mesa Verde Constr. Co. v. Northern Cal. Dist. Council of Laborers, 861 F.2d 1124, 1129-31 (9th Cir. 1988) (en banc) (interpreting Chevron to permit agency to change interpretation notwithstanding Supreme Court affirmance of prior view).

90. 110 S. Ct. 2759 (1990).

91. Id. at 2768 . 
outcome does not follow from the logic of Chevron and must be counted as yet another qualification on that doctrine.

In short, the post-Chevron decisions explicating the meaning of Chevron reveal much that calls into question the Court's fidelity to the doctrine. In one instance-Cardoza-Fonseca - the Court adopted, albeit only temporarily, an exception that would swallow the rule. Other decisions reveal a pattern of qualifying or compromising the doctrine with other principles suggesting that Chevron rests at best uneasily in the larger body of administrative law.

\section{The Revolution Transformed}

Perhaps the most significant post-Chevron development, however, is a subtle but important modification in the statement of the relevant inquiry at step one. As we have seen, Chevron formulated that inquiry in terms of whether the court could "clearly" discern that Congress "had an intention on the precise question at issue." ${ }^{\prime 92}$ If this threshold requirement were faithfully followed, there is little doubt that it would mark a major shift of interpretative power toward the executive branch: it is a rare case where a court can fairly say that Congress thought about, let alone formulated a clear view on, the precise issue in controversy. The "specific intentions" formulation therefore operates as an engine of judicial deference. By the same token, however, if the threshold determination for independent judicial resolution at step one were described differently-for example, if courts were instructed to ask whether the statute has a general meaning that resolves the controversy, even if Congress has not specifically addressed the issue at hand-then the balance might shift back toward independent judgment. In short, under the two-step Chevron framework, everything turns on the theory of judicial interpretation adopted at step one. ${ }^{93}$

Post-Chevron cases have in fact begun to change the formulation of the step-one inquiry. The first sign of change was when opinions began to drop any reference to "specific intentions" or whether Congress had "clearly spoken to" the issue at hand and instead described the threshold inquiry simply in terms of whether the statute was "ambiguous" or "unclear." 94 Then, beginning in 1988 with the $K$ Mart Corp. v. Cartier, Inc decision, ${ }^{95}$ a more dramatic change emerged: the Court began to describe the inquiry at step one in terms of whether the statute has a "plain meaning."

92. 467 U.S. at 843 n.9.

93. See Anthony, supra note 7, at 18-25.

94. See, e.g., Mobil Oil Exploration \& Producing Southeast Inc. v. United Distribution Cos., 111 S. Ct. 615 (1991); Pittston Coal Group v. Sebben, 488 U.S. 105 (1988); Honig v. Doe, 484 U.S. 305 (1988); Young v. Community Nutrition Inst., 476 U.S. 974 (1986).

95. 486 U.S. 281 (1988). The $K$ Mart approach was anticipated in Bethesda Hosp. Ass'n v. Bowen, 485 U.S. 399 (1988), Justice Kennedy's first opinion for the Court.

96. See, e.g., Demarest v. Manspeaker, 11I S. Ct. 599 (1991) (offering no deference to administrative construction that is contrary to plain language of statute); Sullivan v. Stroop, 110 S. Ct. 2499 (1990) (upholding agency interpretation as being compelled by plain meaning of statute); Public Employees 
"new textualism" espoused more generally by Justices Scalia and Kennedy, ${ }^{97}$ has not been followed uniformly. Some opinions continue to quote the language of Chevron about whether Congress has spoken to the precise question at issue. ${ }^{98}$ The trend, however, has been strongly away from the original Chevron formulation of step one.

What are the consequences of substituting textualism for intentionalism at step one? By itself, such a shift does not necessarily reduce deference. Indeed, if the inquiry at step one is formulated in terms of whether the statutory text discloses that Congress has spoken to the precise question at issue, this results in even greater deference to agency views, because Congress has undoubtedly "spoken to" fewer issues in text than it has through some combination of textual and nontextual sources. But at the same time that the Court has dropped the language of intent and substituted the language of plain meaning, it has also dropped the reference to "the precise question at issue." In $K$ Mart, for example, Justice Kennedy's opinion stated that in ascertaining whether there is a plain meaning, "the court must look to the particular statutory language at issue, as well as the language and design of the statute as a whole." ${ }^{99}$ In this fashion, the "plain meaning" inquiry has tended in practice to devolve into an inquiry about whether the statute as a whole generates a clearly preferred meaning. ${ }^{100}$

The movement from "specific intention" to "plain meaning" to "plain meaning considering the design of the statute as a whole" is but one short step away from "best meaning." In other words, with a shift at step one from the "specific intentions" rubric to the "plain meaning" rubric, the Court has moved the threshold inquiry a long way toward the exercise of independent judgment. Justice Scalia has candidly admitted that the use of textualism at step one has this consequence:

One who finds more often (as I do) that the meaning of a statute is apparent from its text and from its relationship with other laws, thereby finds less often that the triggering requirement for Chevron deference exists. It is thus relatively rare that Chevron will require me to accept an interpretation which, though reasonable, I would not personally adopt. Contrariwise, one who abhors a "plain meaning" rule, and is willing to permit the apparent meaning of a statute to be impeached

Retirement Sys. v. Betts, 492 U.S. 158, 171 (1989) ("[N]o deference is due to agency interpretations at odds with the plain language of the statute itself.").

97. See generally William N. Eskridge, Jr., The New Textualism, 37 UCLA L. REV. 621 (1990); Patricia M. Wald, The Sizzling Sleeper: The Use of Legislative History in Construing Statutes in the 1988-89 Term of the United States Supreme Court, 39 AM. U. L. REV. 277, 281 (1990).

98. See, e.g., Pension Benefit Guar. Corp. v. LTV Corp., 110 S. Ct. 2668 (1990); Mead Corp. v. Tilley, 490 U.S. 714 (1989).

99. 486 U.S. at 291 (emphasis added). Four Justices joined this portion of Justice Kennedy's opinion, making it the opinion of the Court.

100. For examples of this trend, see Dole v. United Steelworkers, 110 S. Ct. 929 (1990); Sullivan v. Zebley, 110 S. Ct. 885 (1990); Public Employees Retirement Sys. v. Betts, 492 U.S. 158 (1989). 
by the legislative history, will more frequently find agency-liberating ambiguity, and will discern a much broader range of "reasonable" interpretation that the agency may adopt and to which the courts must pay deference. The frequency with which Chevron will require that judge to accept an interpretation he thinks wrong is infinitely greater. ${ }^{101}$

In short, the merger of the two-step Chevron framework and Justice Scalia's "plain meaning" approach to statutory construction, if consistently followed, would dramatically transform Chevron from a deference doctrine to a doctrine of antideference.

Table 3, which collects the results from Table 1 into two time periods, suggests that the $K$ Mart reformulation may mark the beginning of such a transformation. The first period spans the 1985 and 1986 Terms. Chevron was reasonably well established by this time; it had been expressly reaffirmed in Chemical Manufacturers Ass' $n$ v. National Resources Defense Council ${ }^{102}$ in the previous year, and had not yet encountered any significant controversy. The second period covers the 1988 to 1990 Terms-after the Cardoza-Fonseca episode and after the plain meaning reformulation of step one in $K$ Mart. Table 3 indicates that the Chevron framework was used more frequently in the second period than in the first (going from $32 \%$ of deference cases to $52 \%$ ). This is perhaps what one would expect, given the prominence accorded Chevron by the controversies that erupted in Cardoza-Fonseca and other cases. However, the rate of acceptance of the agency construction went down between the two periods (from $66 \%$ to $50 \%$ ), as indeed did the acceptance rate in all deference cases (from $72 \%$ to $59 \%$ ).

TABLe 3. Post-Chevron Terms in Two Periods

\begin{tabular}{|c|c|c|c|c|c|c|}
\hline TERM & $\begin{array}{c}\text { A } \\
\text { TOTAL CASES } \\
\text { INVOLVNG } \\
\text { DEFERENCE } \\
\text { QUESTION }\end{array}$ & $\begin{array}{c}\text { AGENCY VIEW } \\
\text { ACCEPTED }\end{array}$ & $\begin{array}{c}\text { C } \\
\text { CHEVRON } \\
\text { FRAMEWORK } \\
\text { APPLIED }\end{array}$ & $\begin{array}{c}\text { D } \\
\text { CHEVRON } \\
\text { FRAMEWORK: } \\
\text { AGENCY VIEW } \\
\text { ACCEPIED }\end{array}$ & $\begin{array}{c}\text { E } \\
\text { CHEVRON } \\
\text { FRAMEWORK: } \\
\text { DECIDED AT } \\
\text { STEP TWO }\end{array}$ & $\begin{array}{l}\text { CASES CITnNo } \\
\text { TRADITIONAL } \\
\text { Factors }\end{array}$ \\
\hline $1988-90$ & 34 & $20(59 \%)$ & $18(51 \%)$ & $9(50 \%)$ & $5(30 \%)$ & $16(47 \%)$ \\
\hline $1985-86$ & 25 & $18(72 \%)$ & $8(32 \%)$ & $6(66 \%)$ & $5(62 \%)$ & $8(35 \%)$ \\
\hline
\end{tabular}

101. Scalia, supra note 39 , at 521. Note that Justice Scalia's explanation for why textualism would result in less deference is quite different from mine. He seems to believe that textualism leads to determinate results in most cases and that introducing evidence of intent to "impeach" the text muddies things up and thus requires deference. My argument is that textualism will answer the "precise question" at issue in so few cases that it leads courts to abandon the quest for specific congressional answers, thus allowing a dramatically expanded judicial role at step one.

102. 470 U.S. 116 (1985). 
Again, the shift is produced by changes in only a handful of cases, and the precise percentages are not that meaningful. But it is possible that what we are seeing here is at least caused in part by the emergence of the new plain meaning approach to step one associated with $K$ Mart. Some confirmation of this is supplied by the number of cases reaching step two of the Chevron framework. The more expansive the theory of the judicial role is at step one, the fewer occasions there are to move on to step two. Although the Court has not given much consideration to step two at any time throughout the post-Chevron period, it is interesting to note that the frequency declined even further between the earlier and later periods.

\section{WHAT'S WRONG WITH CHEVRON?}

Chevron's adoption of a general theoretical framework for structuring the choice between independent judgment and deference was an important advance over the formlessness of the previous era. Unfortunately, evidence is mounting that the Court picked the wrong framework. I have already described the primary symptom of dysfunction: the lack of congruence between Chevron and the actual practice of the Supreme Court in determining whether or to what extent to defer to administrative interpretations of statutes. Theory and practice diverge in many ways: the failure to apply Chevron in at least half the cases in which, by its own terms, it should govern; the continuing use of traditional factors of deference which Chevron appears to render irrelevant; the creation of numerous exceptions to Chevron that do not seem to cohere with the decision's rationale; the development of a different version of the Chevron doctrine that greatly expands the judicial role at step one.

It is possible to argue that these manifold deviations simply reflect lapses of judgment on the part of the Court, and that the proper response is to identify the "true" version of Chevron and exhort the Justices to follow it consistently. But the divergences between theory and practice canvassed in Part II are so pervasive that it is difficult to attribute the problem simply to judicial backsliding. Supreme Court Justices are practical individuals, sensitive to the traditions of American constitutionalism, and the Court's persistent refusal to abide by the narrow strictures of Chevron suggests that there must be something wrong with either Chevron's implicit theory of deference, or its practical implications, or both. In this part, I will attempt to spell out why Chevron is incompatible with fundamental tenets of American public law, and why the framework proves to be so unsatisfactory in practice.

\section{A. Chevron Theory}

Chevron raises issues that go the heart of our understanding of the judicial role under a system of separation of powers. In terms of formal separation of 
powers theory, ${ }^{103}$ interpretation of law is often said to be the exclusive province of the judiciary. ${ }^{104}$ This raises the "Marbury problem": if it is the role of courts to "to say what the law is," 105 then how can courts defer to the views of another branch of government on the meaning of the law? ${ }^{106}$ In terms of a functional theory of separation of powers, the purpose of an independent judiciary is often described in terms of its capacity for checking arbitrariness and aggrandizement by the other branches of government. ${ }^{107}$ This raises the problem of agency accountability: how can we structure judicial review of agency action so that agencies have enough discretion to implement complex regulatory programs, and yet assure that they do not become a tyrannical "Fourth Branch" of government, immune from popular control?

One of the strengths of the Chevron doctrine is that it offers, if only implicitly, answers to the Marbury and agency accountability problems. The answers it provides, however, are radically different from those that were put forth in the past, and are difficult to square with other, more enduring commitments about the proper role of the courts in a system of separated powers.

In the early days of modern administrative law, the Marbury and agency accountability dilemmas were usually resolved by borrowing from longstanding notions about the relationship between judges and juries. Courts would defer to agency findings of fact, but would decide all questions of law de novo. ${ }^{108}$ Under such a division of labor, courts would clearly retain final authority to "say what the law is." And by independently ascertaining the meaning of the agency's statutory authority in all cases, courts would provide a powerful constraint against arbitrariness and aggrandizement.

This solution was short lived, however. The comparative advantage of agencies is not limited to finding facts (or applying the law to facts), but extends to resolving many questions of law as well. And if courts decide all questions of law de novo-even where the meaning of the law is uncertain - then the price of containing agency aggrandizement is very likely to be judicial aggrandizement. In response to these shortcomings, the Court abandoned the judge-jury model soon after the Administrative Procedure Act

103. On the distinction between formal and functional theories of separation of powers, see Rebecca L. Brown, Separated Powers and Ordered Liberty, 139 U. PA. L. REv. 1513, 1522-31 (1991); Cass R. Sunstein, Constitutionalism After the New Deal, 101 HARv. L. REV. 421, $493-96$ (1987); Peter L. Strauss, Formal and Functional Approaches to Separation-of-Powers Questions-A Foolish Inconsistency?, 72 CORNELL L. REV. 488 (1987).

104. Wayman v. Southard, 23 U.S. (10 Wheat.) 1, 46 (1825).

105. Marbury v. Madison, 5 U.S. (1 Cranch) 137, 177 (1803).

106. See Monaghan, supra note 6, at 2; Eric M. Braun, Note, Coring the Seedless Grape: A Reinterpretation of Chevron U.S.A., Inc. v. National Resources Defense Council, 87 CoLUM. L. REV. 986, 988-89, 994-95 (1987).

107. Richard H. Fallon, Jr., Of Legislative Courts. Administrative Agencies, and Article III, 101 HARV. L. REV. 916, 978 (1988); see also Farina, supra note 6, at 467-99.

108. See Crowell v. Benson, 285 U.S. 22 (1932); JAFF, supra note 13. 
was enacted, gradually developing the multifactored contextual approach that, as we have seen, dominated the pre-Chevron era. ${ }^{109}$

Chevron in effect advances a third solution to the Marbury and agency accountability problems. The Marbury problem is resolved by a theory of congressionally mandated deference. Courts reconcile their duty to "say what the law is" with the practice of deferring to agency interpretations of law by positing that Congress, in conferring authority on an agency to administer a statute, has implicitly directed courts to defer to the agency's legal views. Accountability is achieved under Chevron by reducing the role of judicial review and relying instead on Presidential oversight.

Both halves of the Chevron solution are problematic at best. The mandatory deference solution to the Marbury problem rests entirely on the presumption that when Congress delegates the authority to administer a statute to an agency, it wants courts to defer to that agency's interpretations of law. The evidence that would support such a presumption is weak. Congress has never enacted a statute that contains a general delegation of interpretative authority to agencies. The very practice of enacting specific delegations of interpretative authority suggests that Congress understands that no such general authority exists. Moreover, the one general statute on point, the Administrative Procedure Act, directs reviewing courts to "decide all relevant questions of law." 110 If anything, this suggests that Congress contemplated courts would always apply independent judgment on questions of law, reserving deference for administrative findings of fact or determinations of policy.

The strongest evidence in support of the Court's presumption is the fact that Congress knows about the practice of judicial deference to agency interpretations and has not acted to prohibit it. ${ }^{111}$ But in order to establish that Congress has mandated the practice of deference, the Court should be able to point to more than a debatable inference from congressional inaction. ${ }^{112} \mathrm{Chev}$ -

109. See supra notes 7-29 and accompanying text. I describe how the contextual approach can be squared with the Marbury and agency accountability concerns at infra text accompanying notes 175-76 and accompanying text.

110. 5 U.S.C. $\$ 706$ (1988) (emphasis added).

111. For a number of years, Senator Dale Bumpers gathered considerable support for a proposed amendment to the APA that would have affirmatively prohibited any judicial deference to agency interpretations of law. See generally James T. O'Reilly, Deference Makes a Difference: A Study of Impacts of the Bumpers Judicial Review Amendment, 49 U. CIN. L. REV. 739 (1980). Failure to enact the Bumpers Amendment may suggest congressional ratification of the deference doctrine. Drawing inferences from unenacted legislation is always hazardous, however, and here more so than usual. Although the Bumpers Amendment was never enacted, it drew consistent (and overwhelming) support-hardly suggesting that Congress is in fact strongly committed to the deference doctrine. Instead, Congress may have failed to approve the amendment out of inertia, because of timing problems, or because the impact of deference is too diffuse to generate the concentrated political support needed to produce legislative action. See Farina, supra note 6 , at $473-74$.

112. A recent decision dealing with judicial deference to an agency's interpretations of its own regulations sought to explain the practice of deference in terms of a presumption of congressional intent based on the agency's "historical familiarity" with the issue and its "policymaking expertise." Martin v. Occupational Safety \& Health Review Comm'n, 111 S. Ct. 1171, 1177 (1991). In Martin the argument in favor of the presumption of intent is based on policy arguments in favor of deferring to executive views, 
ron itself, in defining the judicial role in the interpretation of statutes, suggested that courts have no authority to impose decisional rules that cannot be traced to an authoritative judgment of Congress. Yet the Court could point to no statute indicating that Congress has required that agencies, rather than courts, interpret ambiguities and gaps in statutes. ${ }^{113} \mathrm{~A}$ decisional framework that rests on two foundations, one of which contradicts the other, is difficult to regard as sound.

Chevron's solution to the agency accountability problem is also unsatisfactory. Unlike previous discussions of the accountability problem, which tended to assume that popular control comes about only through the election of representatives who pass statutes that are then enforced by courts, Chevron perceives a dual channel of popular control: one operating through the election of representatives who pass statutes; the other through the election of the President who directs the agents who implement those statutes. The Court sought to forge a formula that would allow both channels of popular control to operate by limiting courts to the enforcement of unambiguous legislative directives, leaving all discretionary decisions to be disciplined by Presidential oversight.

The Court's perception that there is a dual channel of control is an important insight. ${ }^{114}$ But Presidential oversight has inherent limitations. Many administrative entities-including the "independent" regulatory agencies and "legislative" or Article I courts-enjoy various degrees of statutory immunity from direct Presidential control. ${ }^{115}$ Several prominent separation of powers decisions handed down since Chevron have legitimized these immunities, ${ }^{116}$ diluting the power of the President to assure overall direction of those agents who administer the law. But even without the Court's sanction for these immunities, it is simply unrealistic, given the vastness of the federal bureaucracy, to expect that the President or his principal lieutenants can effectively monitor the policymaking activities of all federal agencies. ${ }^{117}$ Nor does it

the assumption being that if the Court finds these policies persuasive then Congress must too. Again, however, the Court cited no direct evidence that Congress has in any context actually endorsed these policies.

113. See Michael Hertz, Textualism and Taboo: Interpretation and Deference for Justice Scalia, 12 CARDOZO L. REV. 1663, 1665-68 (1991).

114. See Harold Bruff, Legislative Formality, Administrative Rationality, 63 TEX. L. REv. 207, 217 (1984); Lloyd Cutler \& David Johnson, Regulation and the Political Process, 84 YALE L.J. 1395, 1410-12 (1975); Richard J. Pierce, Jr., The Role of the Judiciary in Implementing an Agency Theory of Government, 64 N.Y.U. L. REV. 1239 (1989).

115. See Miller, supra note 44; Peter L. Strauss, The Place of Agencies in Government: Separation of Powers and the Fourth Branch, 84 COLUM. L. REV. 573 (1984).

116. See Freytag v. Commissioner, 111 S. Ct. 2631 (1991) (suggesting that it is constitutionally permissible for Congress to create an Article I court outside both the executive and the judicial branches); Mistretta v. United States, 488 U.S. 361 (1989) (upholding statute creating a commission exercising rulemaking power as part of the judicial branch); Morrison v. Olson, 487 U.S. 654 (1988) (upholding statute creating independent prosecutor insulated from removal by the President or Attorney General except for good cause).

117. See Strauss, supra note 115. 
seem wise or appropriate to leave control of agency behavior to congressional oversight hearings. ${ }^{118}$ In the end, the primary protection against arbitrary or aggrandizing action by agencies must remain the fundamental constitutional limitation on all executive action - that it "comport with the terms set in legislative directives." 119 And the only effective institutional mechanism for preserving this constraint is judicial review.

To be sure, Chevron does not eliminate all judicial enforcement of legal limitations on executive action. But by restricting courts to enforcement of "specific intentions" or "clear and unambiguous" statutory directives, it seriously weakens the primary check on agency abuses while offering no adequate alternative in its place. Of particular concern here is the matter of enforcing boundary limitations. Over the years, the Supreme Court has permitted increasingly broad delegations of discretionary authority to agencies, but only on the understanding that the exercise of this delegated authority would be subject to independent judicial review. ${ }^{120}$ To the extent that broad delegations are often ambiguous, Chevron undermines this understanding by suggesting that courts must defer to an agency's interpretation of the scope of its own authority. ${ }^{121}$ As Professor Cynthia Farina puts it:

[A key assumption of Chevron-] that Congress may give agencies primary responsibility not only for making policy within the limits of their organic statutes, but also for defining those limits whenever the text and surrounding legislative materials are ambiguous - is fundamentally incongruous with the constitutional course by which the Court came to reconcile agencies and separation of powers. ${ }^{122}$

A possible solution to this particular difficulty would be to carve out yet another exception to Chevron, this time for decisions that implicate the scope of the agency's own jurisdiction. In fact, three Justices endorsed just such an exception in Mississippi Power \& Light Co. v. Mississippi ex rel. Moore. ${ }^{123}$ The difficulty with the proposed exception, as Justice Scalia pointed out in his concurring opinion, is that virtually any decision about the meaning of the

118. See Richard J. Lazarus, The Neglected Question of Congressional Oversight of EPA: Quis Custodiet Custodes (Who Shall Watch the Watchers Themselves)?, LAW \& CONTEMP. PROBS. 205 (Autumn 1991) (describing multiple difficulties associated with congressional oversight of EPA).

119. Harold J. Krent, Separating the Strands in Separation of Powers Controversies, 74 VA. L. REV. 1253,1256 (1988).

120. See Touby v. United States, 111 S. Ct. 1752, 1757-58 (1991), where the Court rejected a nondelegation doctrine challenge to regulations not subject to judicial review, but only after concluding that the regulations could be reviewed in individual enforcement actions. Justice Marshall's concurring opinion expressly stated that the availability of judicial review was critical to the conclusion that the delegation was constitutional. Id. at 1758 (Marshall, J., concurring); see also Skinner v. Mid-America Pipeline Co., 490 U.S. 212, 218-19 (1989); Yakus v. United States, 321 U.S. 414, 426 (1944).

121. Farina, supra note 6, at 487-88; Cass R. Sunstein, Interpreting Statutes in the Regulatory State, 103 HARV. L. REV. 407, 446 (1989).

122. Farina, supra note 6 , at $487-88$.

123. 487 U.S. 354, 386-87 (1988) (Brennan, J., dissenting, joined by Marshall \& Blackmun, JJ.). 
substantive terms of a statute can be viewed as either expanding or contracting an agency's "jurisdiction." 24 The question at issue in Chevron itself, concerning the proper definition of a "stationary source" of air pollution, has implications for the scope of the EPA's regulatory power. So a "jurisdictional questions" exception to Chevron would either swallow the rule or lead to arbitrary decisions based on explication of a notorious formalism ("jurisdiction").

In sum, Chevron seeks to resolve the central theoretical problems of the modern administrative state by adopting a dubious fiction of delegated authority and by reducing the role of the courts to a point that threatens to undermine the principal constitutional constraint on agency misbehavior. Given these failings, it is small wonder that the Court often seems wary of the Chevron doctrine, applying it inconsistently at best.

\section{B. Chevron Practice}

The Court's general failure to abide by the teachings of Chevron-whether by acts of omission or commission-also suggests that the framework frequently generates unwanted results. There are a number of reasons why Chevron does not function well as a guide to determining the relative weight to be given to judicial and agency views.

\section{The Sequential Inquiry}

Perhaps the most basic problem stems from the fact that Chevron casts the relevant determinants in a sequential hierarchy: consideration of judicial competence first, consideration of administrative competence second. By sequencing the inquiry in this fashion, Chevron almost guarantees that in every case the independent views of the judiciary will be given either too much or too little weight, and concomitantly, that the views of the agency will be given either too little or too much deference. If the issue is resolved at step one, then the court gives no consideration to the views of the executive and decides the matter independently. If the issue is resolved at step two, then the court regards the agency view as dispositive, unless it can say that it is unreasonable. In other words, Chevron inevitably generates "one-sided" decisions. In those cases where the Court feels that one-sidedness is appropriate, Chevron will do fine. But if the Court perceives that a more refined approach is called for, Chevron is a source of awkwardness. The predominant solution in the latter situation appears to be to ignore Chevron.

For example, Chevron seems to rule out the previously common practice of using executive interpretations as a "comfort factor" to confirm a judicial

124. Id. at 381 (Scalia, J., concurring). 
interpretation based primarily on the text and legislative history ${ }^{125}$ If all cases fell into neat piles-unambiguous statutes in one pile, ambiguous statutes in the other-this would entail no loss. Realistically, however, there is a broad gray area where the existence of an administrative interpretation might help tip the balance. Surely it makes no sense to forbid courts to draw upon the consensus of the two branches in assuring the public that the correct result has been reached in such a case.

Similarly, it was possible under the pre-Chevron regime to look to executive interpretations to disconfirm a conclusion based on an independent analysis of text and history. Thus, even if the court found that judicial precedent or the text suggested one answer, it might find this tentative judgment outweighed if, say, a contrary administrative interpretation had been consistently followed for many years, and this executive view had been ratified by a subsequent Congress. ${ }^{126}$ Chevron's sequential inquiry renders it impossible to reach this kind of result. Although allowing administrative interpretations to overcome independent analysis in this fashion is more controversial, it is really not that different from the common practice of allowing judicial precedent to overcome a conclusion drawn from an independent examination of text and history. ${ }^{127}$ Indeed, allowing especially strong executive interpretations to dominate judicial readings provides a way of injecting a dynamic or evolutionary element into statutory interpretation-in a way that is far more consistent with democratic theory than permitting courts to do the updating. ${ }^{128}$

The other half of the one-sidedness problem, of course, is that Chevron eliminates any significant judicial input at step two. In practice, this has proved to be less of a problem because a court that is convinced that judicial input would be desirable has ways of avoiding the conclusion that the case should be decided at step two: it can "rig" the inquiry at step one, either by overstating the evidence that Congress had a specific intention or, more likely today, by finding that the meaning of the statute is "plain." There are several examples

125. See supra text accompanying note 9.

126. See, e.g., Guardians Ass'n v. Civil Serv. Comm'n, 463 U.S. 582, 591-93 (White, J.); id. at 619-20 (Marshall, J., dissenting) (stating that longstanding agency interpretation ratified by Congress should prevail over contrary interpretation suggested by prior Supreme Court opinion); Bob Jones Univ. v. United States, 461 U.S. 574, 599 (1983) (relying on agency interpretation ratified by Congress to bolster conclusion supported only weakly by statutory text and history); see also John P. Dwyer, The Pathology of Symbolic Legislation, 17 ECOLOGY L.Q. 233, 284-315 (1990) (arguing that courts should defer to agency interpretation mitigating the extreme consequences of "symbolic" environmental laws).

127. See Patterson v. McLean Credit Union, 491 U.S. 164, 173 (1989).

128. Judicial updating not only violates norms of democratic legitimacy, but is also inconsistent with the concept of judicial "interpretation" as conventionally understood. See Steven D. Smith, Law Without Mind, 88 MICH. L. REV. 104 (1989) (criticizing T. Alexander Aleinikoff, Updating Statutory Interpretation, 87 MiCH. L. REV. 20 (1987)); see also William N. Eskridge, Jr., Dynamic Statutory Interpretation, 135 U. PA. L. REv. 1479 (1987) (advocating interpretation of statutes in light of evolving societal, political, and legal context). 
among recently decided cases that I would put in this category. ${ }^{129}$ Alternatively, the court can simply ignore the Chevron framework, following the Supreme Court's most common avoidance device. But both techniques rest on misapplication of supposedly controlling law and represent an unhappy solution to a problem that should not exist. It would seem far better to devise a method for courts to articulate their misgivings directly.

\section{The Dividing Line}

A second set of problems is generated by the method for determining the dividing line between the two steps in the sequential inquiry. As we have seen, the balance is determined by the theory of interpretation adopted at step one. As originally formulated, Chevron described the judicial inquiry in such a way that it would almost certainly produce routine deference to agency views.

Chevron's theory of the judicial role at step one is the statutory analogue of what in constitutional law has been called "strict intentionalism." As Dean Paul Brest has put it, "Strict intentionalism requires the interpreter to determine how the adopters would have applied a provision to a given situation, and to apply it accordingly." 130 The problem with such a theory of interpretation is that no matter how precise the meaning of the text, unanticipated questions will invariably arise about how the text is to apply in different circumstances. ${ }^{131}$

129. See, e.g., Dole v. United Steelworkers, 494 U.S. 26 (1990) (rejecting Office of Management and Budget's construction of the Paperwork Reduction Act largely on the basis of structural arguments and canons of construction); Sullivan v. Zebley, 493 U.S. 521 (1990) (rejecting the Secretary of Health and Human Service's interpretation of the Social Security Act based on inferences drawn from reading two provisions together and equitable considerations); Public Employees Retirement Sys. v. Betts, 492 U.S. 158 (1989) (finding an agency interpretation of the Age Discrimination in Employment Act contrary to the "plain meaning" of the statute, even though determining the precise meaning of the Act was a "somewhat more difficult task").

130. Paul Brest, The Misconceived Quest for the Original Understanding, 60 B.U. L. REV. 204, 222 (1980). Such a theory of interpretation is vulnerable to attack for all the reasons textualists like Justice Scalia attack intentionalism generally: Congress enacts texts, not intentions, see, e.g., Pennsylvania y. Union Gas Co., 491 U.S. 1, 29 (1989) (Scalia, J., concurring in part and dissenting in part); In re Sinclair, 870 F.2d 1340 (7th Cir. 1989) (Easterbrook, J.) (holding that where conflict exists, language of statute prevails over legislative history); U.S. DEP'T OF JUSTICE, USING AND MISUSING LEGISLATIVE HISTORY: A REEVALUATION OF LEGISLATIVE HISTORY IN STATUTORY INTERPRETATION (1989); reconstructing historical intentions is very difficult given the limited information we have available; see, e.g., Wisconsin Pub. Intervenor v. Mortier, 111 S. Ct. 2476, 2488 (1991) (Scalia, J., concurring) (stating that committee reports are unreliable as a "genuine indicator of congressional intent"); and heavy reliance on legislative history leads to strategic manipulation by legislative insiders, see, e.g., Blanchard v. Bergeron, 489 U.S. 87, 97 (1989) (Scalia, J. concurring) (suggesting that references to district court decisions were inserted in committee report by staffers "to influence judicial construction"). But it is not my purpose here to take sides in the debate between intentionalism (whether of the strict or general variety) and textualism. The only point is that the particular brand of intentionalism endorsed by Chevron-strict intentionalism-results in a very small role for courts at step one.

131. See REED DICKERSON, THE INTERPRETATION AND APPLICATION OF STATUTES (1975); Frank Easterbrook, The Role of Original lntent in Statutory Construction, 11 HARV. J.L. \& PUB. POL'Y 59, 62-63 (1988). The point has been recognized in a variety of contexts. See, e.g., Robert Bennett, Objectivity in Constitutional Law, 132 U. PA. L. REV. 445 (1984); Martha Field, Sources of Law: The Scope of Federal Common Law, 99 HARV. L. REV. 881, 942-45 (1986). 
In the familiar example, ${ }^{132}$ if the statute says "no vehicles are permitted in the park," does this language apply to bicycles? Or, if the legislature anticipates this application, and provides that "no motor vehicles are permitted in the park," does this version apply to motorized wheel chairs? Given the limits of human imagination, it is virtually impossible for the legislature to formulate a specific intention about how a provision should be applied to all or even most situations. The process of application, especially over time, will always outrun the understanding of even the most farsighted legislature. For this reason, to ask the interpreter to "ascertai[n] that Congress had an intention on the precise question at issue," as Chevron demands, ${ }^{133}$ is to ask a question that will yield an affirmative answer-at least an honest affirmative answer-in only a tiny number of cases. ${ }^{134}$

Under the Chevron framework, there is only one way to expand the small judicial role contemplated by the specific intentions theory-reformulate the nature of the inquiry at step one. The cure, unfortunately, may be as bad as the disease. As we have seen, recent decisions have begun to drop the specific intentions requirement in favor of a "plain meaning" formulation. ${ }^{135}$ But this leaves unanswered several critical questions about what kinds of interpretative aids courts may consult at step one. Must the court find the statute plain on its face? Or may it be plain after consulting extrinsic sources, like dictionary definitions, definitions contained (explicitly or implicitly) in other statutes, or considerations of the structure of the act? In its more latitudinarian versions, where the court looks to considerations of structure and purpose in deciding whether the meaning is "plain," the plain meaning inquiry tends to converge with a "clearly preferred meaning" approach. ${ }^{136}$ If this happens, then Chevron would suffer from the exact opposite of the problem that plagued the original formulation: if step one does not completely swallow step two, at least it will have dramatically expanded-perhaps too far-in the opposite direction.

On other occasions the Court has not committed to either a "specific intentions" method, or to a textualist method, but has stated the relevant inquiry simply in terms of whether the statute is "ambiguous" or "unclear." 137 This formulation leaves even more questions unanswered. To what extent may the court resolve the meaning of the statute at step one based on inferences drawn from legislative history or considerations of statutory purpose? May it use canons of construction based on linguistic usage? Canons based on substantive

132. See, e.g., H.L.A. HART, THE CONCEPT OF LAW (1961); Brest, supra note 130, at 209-10.

133. Chevron U.S.A., Inc. v. National Resources Defense Council, 467 U.S. 837, 843 n.9 (1984).

134. The Court has recognized this point outside the Chevron context. See Moskal v. United States, 111 S. Ct. 461, 467 (1990) ("This Court has never required that every permissible application of a statute be expressly referred to in its legislative history."); Diamond v. Chakrabarty, 447 U.S. 303, 315 (1980) ("This Court frequently has observed that a statute is not to be confined to the "particular application[s] ... contemplated by the legislators." ") (quoting Barr v. United States, 324 U.S. 83, 90 (1945)).

135. See supra text accompanying note 99.

136. See supra text accompanying note 100 .

137. See cases cited supra note 94. 
policy considerations? Given the wide range of possible answers to these questions, the Chevron framework becomes at best unpredictable, and at worst a vehicle for complete substitution of judicial judgment for the views of the agency.

In short, the reformulation of the judicial inquiry at step one will have at least one of two consequences. First, it will result in a considerable sacrifice of the formality of the original Chevron structure, and with it, much of the simplicity and predictability that made the two-step procedure seem attractive. More problematically, if the reformulation results in a greatly enlarged judicial role at step one-as recent cases suggest may be happening - then it would have the paradoxical effect of elevating the courts rather than agencies to the role of primary policymaker. The original rationale for Chevron - the need to have statutory gaps filled by the most democratically accountable decisionmaker-would be turned on its head.

There are several reasons why we should view the potential transformation of Chevron into a doctrine of antideference with alarm. The practice of deferring to executive interpretations of statutes performs many valuable functions: it allows policy to be made by actors who are politically accountable; it draws upon the specialized knowledge of administrators; it injects an element of flexibility into statutory interpretation; and it helps assure nationally uniform constructions. ${ }^{138}$ As statutes become increasingly complex, and courts tend to be increasingly formalistic in their approach to statutory interpretation, a robust measure of deference to agency interpretations may be, if anything, more imperative than ever before. In fact, if courts do the gap filling at step one under the "plain meaning" nostrum by applying dictionary definitions, rules of grammar, and canons of construction, then the content of national policy will be determined by courts without any consideration of the substantive values at issue in the policy disputes-either those that animated Congress or those articulated by the agency charged with administration of the statute.

Finally, there is a more fundamental difficulty with the focus on judicial interpretation at step one. The Chevron framework makes the decision to defer turn on some conception, either explicit or implicit, of what kind of judicial interpretation is legitimate. But there is no a priori reason why the sphere of deference should always be the exact mirror image of whatever a majority of the Court believes on any given day is permissible in the name of judicial interpretation. Surely there are other variables-such as the degree of the agency's expertise and the existence of reliance interests implicated by the

138. See generally Diver, supra note 11 , at 585-92 (discussing a variety of utilitarian arguments for deference to administrative interpretations, including agency expertise and flexibility); Richard J. Pierce, The Role of Constitutional and Political Theory in Administrative Law, 64 TEX. L. REV. 469, 520-21 (1985) (arguing that deference to agency interpretations promotes political accountability); Silberman, supra note 44 (deference serves ends of democratic theory and uniformity); Peter L. Strauss, One Hundred Fifty Cases Per Year: Some Implications of the Supreme Court's Limited Resources for Judicial Review of Agency Action, 87 COLUM. L. REV. 1093 (1987) (deference required to assure uniformity in interpretation). 
agency's interpretation - that also ought to have some bearing on the decision to defer. By making the transition from independent judgment to deference turn solely on the amenability of the issue to independent judicial resolution, the Chevron framework excludes these considerations.

\section{A New and Improved Chevron?}

Could the Court improve on the present state of affairs by tinkering with the Chevron framework? No doubt some beneficial reforms are possible. For example, the Court could reformulate the inquiry at step one in terms of degree of judicial certitude about statutory meaning, rather than in terms that implicate interpretative method. ${ }^{139}$ Thus, it could ask whether the statute admits of only "one possible meaning," rather than posing the question in terms of whether Congress had a "specific intention" on the point or whether the text of the statute is "plain." Such a reform might offer a "compromise" position on the judicial role that would provide a more robust check on agency misbehavior than the original Chevron without going to the opposite extreme of encouraging judicial substitution of judgment.

But no matter how much tinkering is done with the formulation of the inquiry at step one, a number of serious and irremediable problems would remain. The framework would still provide no logical role for the traditional deference factors; it would still generate one-sided decisions; and it would still require the deference decision to be based exclusively on a consideration of judicial competence to exercise independent judgment to the exclusion of other factors. Moreover, it is unclear that any formulation of the proper judicial inquiry at step one can-over a wide range of cases-satisfactorily reconcile the desire to draw upon the comparative advantages of agencies as interpreters with the desire that courts control agency arbitrariness and aggrandizement. In light of the manifold problems associated with the Chevron doctrine, and the persistent gulf between theory and practice, it is time to consider whether an alternative framework might do better.

\section{The EXeCutive Precedent Model}

In this part, I offer an alternative to Chevron-the executive precedent model. The basic idea assimilates the deference doctrine into the general judicial practice of following precedent. The difference is that the "precedent" the courts would be asked to follow is generated by a different branch of government. Just as courts generally adhere to interpretations of statutes

139. See JAFF, supra note 13 , at 572 (suggesting that the relevant inquiry is whether "the judges are themselves convinced that [a] certain reading, or application, of the statute is the correct-or the only faithful-reading or application"); Sunstein, supra note 4, at 2092 ("If the court has a firm conviction that the agency interpretation violates the statute, that interpretation must fail."). 
embodied in judicial precedents, so they would generally follow the interpretations of statutes embodied in prior decisions by executive branch agencies.

\section{A. Executive Interpretation of Law}

The executive precedent model begins with the premise that entities charged with the execution of the law, including the President, executive departments, and independent regulatory agencies, have an inherent power to interpret enacted laws. Even though the President and the entities that assist the President in the execution of law have no inherent power to "make law,"140 once Congress has delegated authority to executive actors under law, the executive agencies must determine what that law means, and need not await a further delegation of interpretative authority from Congress to do so.

The constitutional basis for an inherent executive power to interpret the law is straightforward. The Constitution expressly grants the President "executive power," and directs the President to see that the laws are "faithfully executed." ${ }^{141}$ The conferral of these powers would seem to presuppose that the President and those who serve under his direction have the capacity to ascertain the meaning of the law. Indeed, law interpretation is an inevitable and necessary byproduct of the performance of the constitutional functions of the executive branch. ${ }^{142}$ Just as courts must interpret the law in order to resolve cases and controversies that arise within their jurisdiction, so executive officials must interpret the law in order to promulgate regulations, bring enforcement actions, instruct employees how to carry out programs, or perform any of the other myriad tasks entrusted to agencies. In fact, because only a fraction of executive actions end up in court, administrative actors engage in law interpretation with greater frequency and over a wider range of cases than courts do. ${ }^{143}$ If only the courts had the capacity to interpret law, our system of government could not continue to function.

Moreover, although executive interpretations occur in a variety of "formats," 144 they share much in common with judicial precedent. ${ }^{145}$ Executive interpretations are usually written, are generally accompanied by statements of

140. See Youngstown Sheet \& Tube Co. v. Sawyer, 343 U.S. 579, 585 (1952) (steel seizure case); Thomas W. Merrill, The Judicial Prerogative, 12 PACE L. REV. (forthcoming 1992).

141. U.S. CoNST. art. II, $\$ \S 1,3$.

142. See Bowsher v. Synar, 478 U.S. 714, 733 (1986) ("Interpreting a law enacted by Congress to implement the legislative mandate is the very essence of 'execution' of the law."); United States v. Nixon, 418 U.S. 683, 703 (1974) ("In the performance of assigned constitutional duties each branch of the Government must initially interpret the Constitution, and the interpretation of its powers by any branch is due great respect from the others."); Frank H. Easterbrook, Presidential Review, 40 CASE W. RES. L. REV. 905 (1989-90).

143. See, e.g., JERRY L. MASHAW, BUREAUCRATIC JUSTICE 186 (1983) (judicial review touches less than one percent of the Social Security disability caseload).

144. See Anthony, supra note 7, at 7-14.

145. See Frederick Schauer, Precedent, 39 STAN. L. REV. 571, 572 (1987) (noting that reliance on precedent not limited to courts of law but "is part of life in general"). 
reasons, ${ }^{146}$ and often respond to arguments by affected entities supporting or opposing the interpretation. Furthermore, the written statements of reasons that accompany executive interpretations serve many of the same functions as do the written opinions that accompany judicial decisions. They establish the legitimacy of the interpretation by demonstrating that the executive construction has a sound basis in law and policy. ${ }^{147}$ They clarify the scope of the interpretation so that similar issues that arise in the future can be quickly resolved without having to "reinvent the wheel." 148 They offer instructions to subordinate employees for applying the interpretation in analogous but nonidentical circumstances. Finally, they explain to members of the public the position the government has taken so that they can make appropriate adjustments in their behavior and plan for the future. ${ }^{149}$ Thus, it seems highly appropriate to speak of executive interpretations as a separate system of precedent-executive precedent. ${ }^{150}$

\section{B. The Judicial System of Following Precedent}

Given that both the executive branch and the judicial branch generate interpretations of statutes that can be regarded as "precedent," what is the basis for the judicial practice of deferring to executive precedent? The executive

146. In this respect at least, it is more natural to speak of executive branch decisions as "precedent" than it would be to speak of congressional legislation as precedent. Administrative agencies, like courts, typically vote to approve official explanations given for their actions, such as agency adjudicatory orders or Federal Register notices. Congress, in contrast, usually does not incorporate statements explaining particular rules set forth in statutes. Explanations may be found in legislative history, but Congress does not as a whole vote to approve legislative history, nor is it sent to the President for his signature or veto. Still, the Court has on occasion treated congressional legislation as "precedent" supporting a particular interpretation of the Constitution. See Field v. Clark, 143 U.S. 649, 690-91 (1892) (treating prior statutes delegating discretion to executive as precedent supporting the constitutionality of delegation). See generally James B. Thayer, The Origin and Scope of the American Doctrine of Constitutional Law, 7 HARV. L. REV. 129 (1893) (arguing that courts should defer to legislative interpretations of ambiguous constitutional provisions).

147. See Henry P. Monaghan, Stare Decisis and Constitutional Adjudication, 88 COLUM. L. REV. 723, 749-55 (1988).

148. See RICHARD WASSERSTROM, THE JUDICIAL DECISION $72-73$ (1961); Schauer, supra note 145, at 599 .

149. See MELVIN A. EISENBERg, THE NATURE OF THE COMMON LAW 10-12 (1988) (discussing the requirement that judicial decisions be "replicable" by private parties and their advisors); Schauer, supra note 145 , at 597-98; WASSERSTROM, supra note 148, at 66-69.

150. Indeed, certain types of administrative decisions-adjudications-have legal consequences largely indistinguishable from judicial decisions. Executive agencies can enter orders for the payment of money (damages) and cease and desist orders (injunctions). See Commodity Futures Trading Comm'n v. Schor, 478 U.S. 833 (1986) (agency may adjudicate common law claim for money damages); American Airlines v. North Am. Airlines, 351 U.S. 79 (1956) (Civil Aeronautics Board may properly issue cease and desist order). Failure to abide by an agency order can result in sanctions for contempt. Regal Knitwear Co. v. NLRB, 324 U.S. 9 (1945). And courts "have long favored application of the common-law doctrines of collateral estoppel (as to issues) and res judicata (as to claims) to those determinations of administrative bodies that have attained finality." Astoria Fed. Sav. \& Loan Ass'n v. Solimino, 111 S. Ct. 2166, 2169 (1991). Although I would not confine the notion of executive precedent to statements of reasons in adjudicatory decisions, the parallel to judicial precedent here is especially striking. 
precedent model locates that practice in the courts' inherent powers to develop principles for resolving cases and controversies. ${ }^{151}$ We know that the "judicial power" described in Article III encompasses the practice of following precedent, even though this practice is not expressly authorized in any source of positive law. ${ }^{152}$ Indeed, the norm of following precedent is ubiquitous in the Anglo-American legal system. The executive precedent model would assimilate the judicial practice of deferring to executive interpretations into this system of following precedent. Courts would be deemed to have inherent authority to develop guidelines for deferring to executive precedents in appropriate circumstances.

This inherent authority, like other products of judicial self-governance (such as common law rules of procedure ${ }^{153}$ ), would be subject to congressional modification. ${ }^{154}$ Thus, if Congress were expressly to instruct courts to defer or not to defer to particular agency interpretations, these instructions would supersede the norms of following precedent. But absent express instructions from Congress about the allocation of authority, courts would develop their own standards for determining when to defer to prior executive interpretations of law.

In determining where executive precedent might fit into the judicial system of following precedent, it is useful to consider briefly the various ways courts treat different types of judicial precedent. None of these understandings is compelled by any statutory or constitutional provision. Rather, they have emerged over the years through a gradual process of judicial self-definition.

Decisions of superior courts are the most powerful form of precedent. They are regarded as legally binding on lower courts. ${ }^{155} \mathrm{~A}$ court's own previous

151. See generally Chambers v. NASCO, Inc., $111 \mathrm{~S}$. Ct. 2123, 2132 (1991) ("It has Iong been understood that '[c]ertain implied powers must necessarily result to our Courts of justice from the nature of their institution,' powers 'which cannot be dispensed with in a Court, because they are necessary to the exercise of all others.' ") (quoting United States v. Hudson, 11 U.S. (7 Cranch) 32, 34 (1812)).

152. There can be no doubt that the Framers of the Constitution understood that the norm of following precedent was an integral element of the functioning of courts. See THE FEDERALIST No. 78, at 471 (Alexander Hamilton) (J. Cooke ed., 1961) ("To avoid an arbitrary discretion in the courts, it is indispensable that they should be bound down by strict rules and precedents."). For example, Blackstone, a familiar legal source to the Framers, pronounced that precedent must be followed "unless flatly absurd or unjust." 1 WILliam BLACKSTONE, COMMENTARIES ON THE LAWS OF ENGLAND 70 (Facsimile ed. 1979).

153. See Sibbach v. Wilson \& Co., 312 U.S. 1, 9-10 (1941); Wayman v. Southard, 23 U.S. (10 Wheat.) 1,43 (1825).

154. In the context of constitutional adjudication, Professor Monaghan has questioned whether Congress would have the authority to direct the Court to disregard the principle of stare decisis. Monaghan, supra note 147, at 754-55. But given Congress' acknowledged power to legislate standards of review of agency action under delegated statutory authority, there can be little doubt that Congress could direct the courts to decide questions of statutory interpretation de novo, or (short of constitutional violation) to deem an agency's interpretation authoritative-or anything in between.

155. See, e.g., Thurston Motor Lines v. Jordan K. Rand, Ltd., 460 U.S. 533, 535 (1983); Hutto v. Davis, 454 U.S. 370,375 (1982). It is not plausible to view this norm as simply grounded in an empirical generalization that a lower court will get reversed by a superior court if it fails to follow superior court precedent. The U.S. Supreme Court, for example, does not begin to have the institutional capacity to review all decisions of the federal courts of appeals to ensure that they remain faithful to Supreme Court precedent. See Peter Strauss, One Hundred Fifty Cases Per Year, 87 ColuM. L. REv. 1093 (1987). The same is 
decisions are not as binding as decisions of superior courts. But their own opinions are also accorded more than deference; under the doctrine of stare decisis, they are regarded as enjoying a very strong presumption of correctness. ${ }^{156}$ In practice, this means they will be followed unless they are overruled, and generally speaking they will be overruled only if there is a very strong justification for doing so. ${ }^{157}$

A third type of precedent is made up of prior decisions of tribunals of coordinate jurisdiction. The most familiar example is when one federal court of appeals confronts an issue that has been decided previously by another court of appeals. Here the judicial attitude is more uncertain. English courts and nineteenth-century American courts developed the doctrine of the "controlling decision," whereby the precedent of a court of coordinate jurisdiction was regarded as binding as a matter of comity. ${ }^{158}$ After the creation of the federal courts of appeals in 1891, and the reconceptualization of the role of the Supreme Court as being devoted largely to the resolution of conflicts between the courts of appeals, the attitude of the federal courts of appeals relaxed considerably. ${ }^{159}$ Some courts came to speak of a duty of following the precedent of another circuit unless it could be said to be "clearly erroneous." 160 Others stressed that such precedent is not "binding," and implied that intercircuit precedent would be followed only to the extent it is "persuasive"-suggesting that it is entitled to no deference at all. ${ }^{161}$ Perhaps the most accurate synthesis of the contemporary understanding is that one court of appeals will "give most respectful consideration to the decisions of the other courts of appeals,"

probably true in many of the large state court systems.

156. California v. FERC, 110 S. Ct. 2024, 2028-30 (1990); Patterson v. McLean Credit Union, 491 U.S. 164, 172 (1989); Square D Co. v. Niagara Frontier Tariff Bureau, Inc., 476 U.S. 409, 424 (1986) (referring to "the strong presumption of continued validity that adheres in the judicial interpretation of a statute" $)$.

157. Patterson, 491 U.S. at 172. It has even been argued that in the statutory context, the presumption of correctness should be absolute. See Lawrence C. Marshall, "Let Congress Do It": The Case for an Absolute Rule of Statutory Stare Decisis, $88 \mathrm{MICH}$. L. REV. 177 (1989).

158. See Alan D. Vestal, Relitigation By Federal Agencies: Conflict, Concurrence and Synthesis of Judicial Policies, 55 N.C. L. REV. 123, 129-40 (1977).

159. Id. at 140-66. Professor Vestal concluded his comprehensive 1977 survey by noting that "the doctrine of controlling decision may not have the vitality it once had," although he thought many of the departures from the doctrine were unexplained, and "the underlying principles that have been the basis for the doctrine of controlling decision have lost none of their vitality." Id. at 166 . For an interesting argument in support of applying a rule of stare decisis to intercircuit precedent-based largely on the desirable effects on the Supreme Court's workload-see Walter V. Schaefer, Reducing Circuit Conflicts, 69 A.B.A. J. 452 (1983); Walter V. Schaefer, Reliance on the Law of the Circuit-A Requiem, 1985 DUKE L.J. 690.

160. See, e.g., Homan v. United States, 279 F.2d 767, 773 (8th Cir.) ("We have in a long line of opinions declared that, on an unsettled question of federal law, while a decision by another Court of Appeals is not compulsively binding upon us, we will, in the interest of judicial uniformity, accept it as persuasive and follow it, unless we are clearly convinced that it is wrong." (citations omitted)), cert. denied, 364 U.S. 866 (1960).

161. See, e.g., City Stores v. Lerner Shops, 410 F.2d 1010, 1014 (D.C. Cir. 1969) ("Decisions of district courts and other courts of appeals are, of course, not binding on us and are looked to only for their persuasive effect.").

162. Colby v. J.C. Penney Co., 811 F.2d 1119, 1123 (7th Cir. 1987) (Posner, J.). 
especially where the prior interpretation is a "reasoned decision" 163 or there is an "accumulation of authority." 164 In effect, a legal interpretation of another circuit is regarded as prima facie correct, and is given more or less deference depending on contextual factors such as the extent of consideration given the issue by the other circuit and how long its precedent has been followed.

Finally, there are precedents of inferior judicial tribunals. A court will nearly always take note of the view of the tribunal whose decision is under review; it is regarded at the very least as an interesting datum. Generally speaking, however, the superior court will resolve all questions of law de novo; the views of the inferior court will be followed only to the extent they are regarded as persuasive. ${ }^{165}$ The decisions of inferior tribunals other than the one under review are noted only sporadically. ${ }^{166}$ Thus, the general understanding is that lower court precedent is not entitled to any measure of deference by the superior tribunal.

Which of the four attitudes toward different types of judicial precedent should provide the relevant benchmark for determining the attitude of courts toward executive precedent? We can quickly dismiss the possibilities that executive precedent should be treated like the decisions of superior courts or like a court's own prior decisions. Part of our received understanding of the "judicial power" is that courts have final say in articulating the meaning of the law in cases brought before them. ${ }^{167}$ It would seem to follow from this that courts are not legally bound by executive interpretations of statutes. For similar reasons, it would seem to be inconsistent with our understanding of the judicial power to posit that courts are bound by executive precedents the way they must follow their own precedents.

The two most plausible models for executive precedent are the treatment of decisions by courts of coordinate jurisdiction and the treatment of decisions by inferior courts. For a variety of reasons, I think that the treatment of decisions by courts of coordinate jurisdiction provides the best analogy. Some of these reasons will unfold only as the full implications of the model are spelled

163. Aldens, Inc. v. Miller, 610 F.2d 538, 541 (8th Cir. 1979), cert. denied, 446 U.S. 919 (1980).

164. IB JAMES W. MOORE ET AL., MOORE'S FEDERAL PRACTICE I 0.402, at 15 (2d ed. 1984).

165. See generally Salve Regina College v. Russell, 111 S. Ct. 1217 (1991) (federal court of appeals should not defer to district court's interpretation of state law in diversity suits).

166. Occasionally one will find the suggestion that a widespread consensus among lower tribunals over a long period of time is entitled to some deference. Reves v. Ernst \& Young, 494 U.S. 56, 74-76 (1990) (Stevens, J., concurring) (Court should defer to unanimous consensus among courts of appeals about meaning of Securities Act exemption); United States v. Ryan, 284 U.S. 167 (1931) (Court should hesitate to set aside uniform construction given to statute by lower courts for more than 60 years). And from time to time, courts will rely on arguments or insights contained in particular lower court decisions, especially if the judge is widely respected. See, e.g., Interstate Commerce Comm'n v. Brotherhood of Locomotive Eng'rs, 482 U.S. 270, 293 n.8 (1987) (Stevens, J., concurring) ("Judge Friendly's discussion on the general issue of denials of petitions to reopen continues to merit our respect.").

167. See United States v. Nixon, 418 U.S. 683, 705 (1974) (rejecting claim of unreviewable executive authority to determine when executive communications are legally privileged); Marbury v. Madison, 5 U.S. (1 Cranch) 137, 170 (1803) (courts have power to compel executive officers to perform legal duty as determined by court). 
out. One overarching reason for selecting the precedent of courts of coordinate jurisdiction as the proper lodestar, however, bears emphasis at the outset.

In comparing the situation of superior courts and inferior courts as law interpreters, the comparative advantage resides almost entirely with the superior court. ${ }^{168}$ Thus, there is no reason for a superior court to defer to the judgments of a trial court on questions of law. But when we compare courts and agencies, there are strengths and weaknesses on both sides of the ledger. Executive interpreters have greater expertise on matters that are highly technical or complex; they have more familiarity with the overall structure of a statutory program, and with the policies followed under those programs; and they are more accountable to the public. On the other hand, courts are more insulated from political pressures than agencies; their members are more likely to be selected for their legal abilities than are agency heads; they may be able to hire better law clerks; and they may have more time to do research and write opinions, if only because they are exempt from the statutory deadlines often imposed on agencies.

The point is not that agencies are always better interpreters than courts are or vice versa, but simply that there are advantages and disadvantages on both sides. This suggests that, at least as a first approximation, the treatment of precedent of courts of parallel authority appears to supply the best benchmark for establishing the judicial attitude toward executive precedent. ${ }^{169}$ Of course, this is just an analogy. There are a number of aspects in which the treatment of executive precedent should differ from that of intercircuit precedent. The analogy is useful, however, for it demonstrates that it is possible to ground the deference doctrine in the practice of following precedent. As we shall see, moreover, the treatment of the precedent of courts of parallel authority appears

168. See Salve Regina College, 111 S. Ct. at 1221; Dan T. Coenen, To Defer or Not to Defer: A Study of Federal Circuit Court Deference to District Court Rulings on State Law, 73 MiNN. L. REv. 899, 923 (1989).

169. If courts should treat the interpretations of executive agencies like the precedent of a tribunal of coordinate jurisdiction, then should agencies treat the opinions of courts the same way, i.e., as only presumptively correct and entitled to more or less weight depending on contextual factors? This is a variation on the problem of agency "nonacquiescence" in judicial interpretations of law. See Samuel Estreicher \& Richard Revesz, Nonacquiescence by Federal Administrative Agencies, 98 YALE L.J. 679 (1989); Vestal, supra note 158. My answer would be that, as a matter of theory, agencies must give judicial precedent no more deference than courts must give executive precedent. Courts render judgments that bind the parties before them (including agencies) and such judgments must of course be obeyed. They also issue statements of reason-opinions-that help readers (including agencies) predict how they will resolve future controversies. But they do not issue edicts that bind all the world, as the Constitution, a statute, or an agency regulation does. See John Harrison, The Role of the Legislative and Executive Branches in Interpreting the Constitution, 73 CORNELL L. REV. 371 (1988); Edwin Meese, III, The Law of the Constitution, 61 TUL. L. REV. 979 (1987). In theory, therefore, agencies could regard judicial precedent the same way courts regard agency precedent.

At a practical level, however, the fact that courts review agencies rather than vice versa may well dictate a more accommodating attitude by agencies. Thus, agencies may wish to "acquiesce" in judicial opinions for future cases even if those opinions are not binding as a matter of law, and even if the agency, as a matter of interbranch precedent-following, is not convinced by the court's analysis. 
to share many of the main features of the administrative deference doctrine as it has been historically practiced and understood.

\section{The Model Stated}

If we view the deference doctrine as part of the system of precedent, then the decision whether or to what extent to defer to executive interpretations would in each case entail a three-part inquiry: (1) Is there an executive precedent? (2) How strong is that precedent? (3) Given the strength of the executive precedent, does an independent judicial examination of the question of statutory interpretation compel a different result?

\section{Is There an Executive Precedent?}

Not every interpretation of law by an executive agency should be regarded as a "precedent," at least for purposes of determining the judicial response. Here, I would suggest that the relevant distinction is between an interpretation initially advanced when the agency is acting as an independent decisionmaker and an interpretation first advanced when the agency is acting as a party to judicial proceedings. Insofar as the agency adopts an interpretation when it is wearing its independent decisionmaker hat, its views should be regarded as "precedent." Included in this category would be any interpretation embodied in a decision by an agency that is legally binding on actors outside the agency itself, such as the promulgation of legislative rules, the issuance of administrative orders, or the award of licenses and grants. In addition, any legal interpretation embodied in an official statement of agency position that predates a particular judicial controversy would count as precedent. Examples would include interpretative rules, policy statements, agency enforcement guidelines, and previous opinion letters.

When an agency initially advances an interpretation while it is wearing its judicial litigant hat, however, the interpretation should not be regarded as precedent. This is not because the agency loses any comparative advantage it may have as an interpreter when it changes hats. Instead, judicial norms about impartial adjudication preclude giving the interpretation precedential weight. When there are two parties before a court contesting the meaning of the law, it is generally understood that the court should decide the matter impartially and independently, without giving one party's views greater weight simply because of that party's status. ${ }^{170}$ Thus, insofar as the agency view is not embodied in a previous authoritative expression of its views, the agency view should be treated as no different from the position of any other party. Examples

170. See Fishgold v. Sullivan Drydock \& Repair Corp., 154 F.2d 785, 789 (2d Cir.), aff' $d, 328$ U.S. 275 (1946); Anthony, supra note 7, at 60 ("It would exceed the bounds of fair play to allow an institutionally self-interested advocacy position, which 'may properly carry a bias,' to control the judicial outcome."). 
of agency action that fall into this category and thus should not be regarded as precedent would include an interpretation implicit in the decision of a prosecutor to file criminal charges, an interpretation reflected in the decision of an agency to institute judicial enforcement proceedings, or an interpretation advanced for the first time in legal briefs filed in court defending a previously taken agency action.

\section{How Strong Is the Executive Precedent?}

Once it is determined that there is an executive precedent on point, the next step would be to ascertain how "strong" it is. This inquiry, which would necessarily be fairly judgmental, would entail two distinct components.

The first component turns on the level in the executive hierarchy from which the intepretation emanates. Under the executive precedent model, the authority of executive agencies to interpret law derives not from a delegation of interpretative authority from Congress, but from the President's executive power and constitutional obligation to see that the laws are faithfully executed. Thus, the more directly accountable the interpreter is to the President, the more the decision would partake of the President's constitutional authority and the stronger it would be regarded as executive precedent. To illustrate: ${ }^{.171}$ an interpretation contained in a letter from a regional office of the Department of Health and Human Services (HHS) would not be as strong as one contained in a "program instruction" adopted by the general counsel of HHS, which would not be as strong as one reflected in a policy directive issued by the Secretary of HHS, which would not be as strong as an interpretation directly approved by the President. This hierarchy of authority, of course, directly parallels the understanding of the strength of precedent in the judicial hierarchy, where the Supreme Court partakes of the "judicial power" by direct grant from the Constitution, and lower courts possess the judicial power only in accordance with their position in relation to the Supreme Court. ${ }^{172}$

The second component of the strength of executive precedent is derived by analogy to the treatment of precedent of courts of coordinate jurisdiction within the system of judicial precedent. Consider some of the factors that a court might look to in determining whether to follow the precedent of a judicial tribunal of coordinate authority: How long has the precedent of the other tribunal been followed? Has it been criticized by later decisions, or is it inconsistent with another precedent of equal status? Has the public come to rely on

171. The illustration is derived from Miller v. Youakim, 440 U.S. 125, 144 n.25 (1979).

172. Unlike the Chevron doctrine, the executive precedent model does not require that there be a unitary executive branch. See supra note 44 . Everything else being equal, however, the greater the "independence" of an executive entity from Presidential oversight and control, the weaker its precedent. Thus, a statutory interpretation adopted by the Securities and Exchange Commission-an "independent" regulatory agency-would be entitled to less deference than would an interpretation adopted by a Cabinet officer such as the Attorney General or the Secretary of HHS, both of whom are removable by the President at will. 
the interpretation? Does the interpretation concern a matter as to which the other tribunal has particular familiarity or expertise? Was the issue fully briefed and argued in the other tribunal, and is the other tribunal's decision supported by a thorough and reasoned opinion? Has the interpretation of the other tribunal been ratified by subsequent congressional action? As developed more fully below, these factors bear an uncanny resemblance to the contextual factors courts developed in the pre-Chevron era in order to determine whether, or to what extent, to defer to executive interpretations. The analogy to intercircuit precedent helps to sharpen our understanding of why many of these factors should be relevant and which ones are most important in particular settings.

\section{Does an Independent Judicial Judgment Compel a Different Result?}

Once the court has established that there is an executive precedent and has determined (roughly) how strong that precedent is, then it must make an independent inquiry to determine whether there is sufficient reason to overcome the presumption of correctness that such a precedent enjoys. In undertaking this inquiry, the court could call upon any and all of the "traditional tools of statutory interpretation"173 that would be relevant in interpreting the statute de novo. The conclusions reached through this kind of analysis-ranging from a judgment that the statute can have only one possible meaning to a conclusion that it is utterly opaque-would then be considered in light of the conclusions reached about the strength of the executive precedent. A strong precedent-such as an interpretation adopted by the Secretary of HHS in a well reasoned decision consistently maintained over a long period of time-would be rejected only if the court were firmly convinced it was wrong. A weak precedent-such as a recent letter from a regional office of HHS asserting the interpretation in a conclusory fashion - would be disregarded if the court had a fair doubt about its correctness.

This is an admittedly imprecise decisional formula. But there are simply too many relevant variables to reduce the inquiry to a simple algorithm. Nor is it particularly surprising that this should be the case. After all, the same must be said of the role of judicial precedent in statutory interpretation: no single formula can capture the process by which courts determine the competing claims of prior judicial precedent and a de novo judicial examination of statutory language and legislative intent. The only difference where executive precedent is involved is that the precedent comes from a different branch of government. $^{174}$

173. Chevron U.S.A., Inc. v. National Resources Defense Council, 467 U.S. 837, 843 n.9 (1984).

174. An alternative basis for a model not grounded in presumed delegation is suggested by the doctrine of practical construction: administrative decisions could be seen as a form of "conduct" that is evidence of the practical construction of a statute by the party charged with its implementation. See Annotation, Effect of practical or administrative construction of a statute on subsequent judicial construction, $73 \mathrm{~L} . \mathrm{Ed} .322$ (1929). The doctrine of practical construction is often encountered in cases construing treaties, see Eastern 


\section{THE MODELS COMPARED}

The proposed executive precedent model shares many of the strengths of the Chevron doctrine in that it strives to encourage courts to defer to the judgments of political actors who have greater public accountability and specialized knowledge. Yet, I will contend, it avoids Chevron's major theoretical and practical failings. Moreover, the model is not radical, unless perhaps one assumes (contrary to fact) that the full-blown Chevron doctrine actually defines the status quo. Indeed, a major part of the justification for the model is that it coheres better with both existing and historical practice than does the Chevron formulation. Finally, the executive precedent idea has consequences for judicial, administrative, and congressional behavior that, on balance, are superior to the effects of Chevron.

\section{A. Overcoming Chevron's Theoretical and Practical Problems}

Any theory of deference must come to terms with the Marbury problem and the problem of agency accountability. We can now see that there are three general strategies for accomplishing these ends. ${ }^{175}$

The first-which prevailed fleetingly when modern administrative law was taking form-is to allow courts to review all questions of law de novo. This solution totally eliminates the Marbury problem and provides a powerful potential check on agency abuse. But it deprives us of any comparative advantage agencies may have as interpreters, and it gives the courts too much discretionary power over the formulation of policy.

The second strategy-that of Chevron-is grounded in the notion of mandatory deference. Courts seek to remain faithful to their duty to "say what the law is" while deferring to executive interpretations by positing that Congress has mandated that they defer. Agency accountability is secured by having courts enforce clear statutory directives and by relying on Presidential oversight. As we have seen, ${ }^{176}$ this strategy, as pursued by Chevron, falls victim to several difficulties, including the need to adopt a doubtful fiction of delegated interpretative authority, and to abandon a good part of the only effective check on the abuse of power by agencies.

Airlines, Inc. v. Floyd, 111 S. Ct. 1489, 1499 (1991); Air France v. Saks, 470 U.S. 392, 403 (1985), and traces its origins to the doctrine of practical construction in the law of contracts. See SAMUEL WILLISTON, A TREATISE ON THE LAW OF CONTRACTS $\$ 623$ (3d ed. 1961). As suggested by these origins, however, the doctrine ultimately rests on the idea of mutual assent-if both parties to an agreement concur in a certain practical implementation, then this suggests that both parties have assented to this construction. The absence of anything resembling a conventional bilateral agreement in the agency setting may make this particular analogy problematic as a basis for a model of deference to administrative decisions.

175. See Stephen Breyer, Judicial Review of Questions of Law and Policy, 38 ADMIN. L. REV. 363, 368-69 (1986).

176. See supra text accompanying notes 7-29. 
The third strategy-that pursued by the executive precedent model-is grounded in discretionary deference. Courts remain faithful to the duty to say what the law is, but in exercising this duty they conclude as a matter of selfgovernance that the best guide to the meaning of the law is often to follow the prior interpretations of a coordinate branch of government. At the same time, courts hold agencies accountable by upholding only the exercise of sound executive discretion: they affirm decisions that present a combination of strong precedent and/or congruence with congressional intent, but they reverse decisions that present a combination of weak precedent and/or tension with congressional intent. This approach therefore allows courts to continue to act as a check on abuse of delegated power.

\section{Theoretical Failings}

By grounding the practice of deference in norms of judicial comity rather than legislative compulsion, the executive precedent model avoids Chevron's most glaring weakness: the need to posit a fictitious delegation of power from Congress to executive agencies. Instead, the practice of deference is derived from two relatively uncontroversial constitutional propositions: (1) executive entities have an inherent power to interpret the laws they are charged with enforcing, and (2) the courts have an inherent power to develop norms for following precedent that can be extended to encompass the practice of deferring to executive precedent.

Because the executive precedent model grounds deference in inherent powers, it is unaffected by the ambiguity over Congress' true intentions regarding the allocation of interpretative authority. Chevron fails in the face of this uncertainty because ambiguity does not add up to a mandatory directive to defer. But if courts have inherent power to decide when to defer, an ambiguous congressional attitude simply means Congress has done nothing that would require courts to desist from their existing practice of deference.

In addition, the model harmonizes better with established understandings of constitutional structure. At a formal level, Chevron recognizes an omnipotent Congress, which is envisioned as not only establishing substantive legal norms, but also as directing the allocation of interpretative authority between executive agencies and courts. But in practice, because of its fiction that Congress has delegated the resolution of all ambiguities to the agencies charged with enforcement of a statute, Chevron sanctions the exercise of vast executive powers unchecked by meaningful judicial review.

The executive precedent model, like Chevron, posits that Congress has ultimate power over the adoption of substantive legal norms. But the allocation of interpretative authority between agencies and courts-at least for purposes of judicial review-is determined by the courts themselves, absent some superseding instruction from Congress. By grounding the practice of deference 
in the discretionary powers of courts, the executive precedent model permits courts to continue to perform an important checking function in reviewing the exercise of delegated power by agencies. In particular, courts would not be required to identify a clear statutory violation before they could decline to follow executive precedent. Other abuses of agency power-including decisions that upset settled expectations, decisions that reflect agency bias, and decisions that seek to expand agency power beyond the sphere contemplated but not expressly spelled out by Congress-would also be subject to judicial correction.

\section{Practical Failings}

The executive precedent model, with its greater flexibility and openness to a wider range of potentially relevant considerations, also avoids the major practical failings of Chevron. By retaining flexibility about the relative weights to be given executive precedent and independent judgment, the executive precedent model avoids the extremes of Chevron, whereby the views of the executive are given either too little or too much weight in virtually every case. In particular, the model ensures that the executive branch view will always be considered, rather than become relegated to a subset of cases in which courts do not feel confident about exercising independent judgment. At a minimum, therefore, the executive precedent model guarantees that the entity with the best grasp of practical consequences-the executive agency-at least gets its views on the table in every case.

The executive precedent model also sidesteps the need to adopt any particular theory of judicial interpretation in order to fix the point at which the court will defer to executive judgment. The model can be wedded to any of the rival methods of interpretation. It is based on a contextual assessment of the "strength" of the executive precedent together with an independent judicial assessment of statutory meaning, with no a priori specification of a single legitimate method for ascertaining meaning.

Finally, the model is open to a wide range of contextual factors that courts continue to regard as important. Under Chevron, the court is instructed to decide whether to defer after looking at only one variable: whether the court is entitled to exercise independent judgment. Other variables related to the agency's authority and its performance are ignored. In effect, the decision whether to defer is made with blinders on. Under the executive precedent model, in contrast, the court looks at both sides of the equation: measuring first the strength of the executive precedent and then considering this measurement against an independent assessment of the clarity of the statute. 


\section{B. Congruence with Practice}

Perhaps even more impressive is the capacity of the executive precedent model to explain various features of the deference doctrine, both the traditional pre-Chevron understanding and the recent exceptions recognized under the Chevron regime.

\section{The Status of Pre-Chevron Factors Under the Executive Precedent Model}

Quite a number of the features of the deference doctrine as it existed in the pre-Chevron era-features that were apparently banished by Chevron, but seem to persist in the actual practice of the Court-suddenly become explicable once we view the practice of deference as a form of following precedent. In particular, most of the deference factors have direct analogues in the practice that courts observe when deciding whether to follow judicial precedent. And the few factors that lack direct analogues have a commonsense basis and can be readily accommodated to the executive precedent rnodel.

(a) Deference As a Sliding Scale. Pre-Chevron practice, as we have seen, treated deference as existing along a sliding scale, ${ }^{177}$ whereas Chevron tends to make deference an all-or-nothing proposition. Viewing deference as a form of following precedent makes sense of the traditional approach. Where judicial precedent is concerned, courts typically do not resolve questions of statutory interpretation solely on the basis of precedent from courts of coordinate jurisdiction. Some nonbinding precedents are considered weightier than others, and considerations drawn from the precedent of other courts are typically weighed against the court's independent analysis of the meaning of the statute. ${ }^{178}$ Similarly, under the executive precedent model, deference to executive views would fall along a continuum, depending on the strength of the executive precedent and the degree of confidence the court has in its independent view of the statute's meaning.

(b) Express Delegations. Pre-Chevron cases also distinguished between "legislative rules" and "interpretative rules." This construct has no direct analogue in the realm of judicial precedent, no doubt because it is rare for

177. See supra text accompanying note 8 .

178. See Colby v. J.C. Penney, Inc., 811 F.2d 1119, 1123 (7th Cir. 1987) (circuit court does not give automatic deference to decisions of other circuits, but recognizes that "within reason, the parties to cases before us are entitled to our independent judgment."); Haberle Crystal Springs Brewing Co. v. Clarke, 30 F.2d 219, 222 (2d Cir. 1929), rev'd on other grounds, 280 U.S. 384 (1930) ("Much as we respect the considered decisions of other circuits, we conceive that our duty requires us to form an independent judgment in cases of first impression in our own court, and forbids us blindly to follow other circuits, when our minds are not persuaded by the arguments advanced."). 
Congress expressly to delegate rulemaking power to courts. ${ }^{179}$ Nevertheless, the basic insight of the legislative/interpretative rule distinction is sound and should be adopted to the executive precedent framework. Any express directive from Congress about the allocation of interpretative authority would supersede the internal norms. But such directives are rare. Short of an express allocation of interpretative roles, a specific congressional grant of authority to agencies in a particular area should be viewed as a congressional judgment of the superior competence of the agency to develop legal norms in the area under consideration, and thus should also result in greater deference to agency interpretations.

I would, however, reject one feature of the pre-Chevron approach to legislative rules. Pre-Chevron case law tended to speak in all-or-nothing terms. Either an agency interpretation was a "legislative rule" entitled to great deference, or it was an "interpretative rule" entitled only to whatever persuasive effect it might have. ${ }^{180}$ Unfortunately, this dichotomy tended to break down in practice. Statutes granting general substantive rulemaking authority to agencies, rather than specific authority to define a particular term, were particularly problematic. ${ }^{181}$ I would avoid crude dichotomies by making the specificity of any express congressional delegation of regulatory authority one contextual factor to be considered in determining the strength of the executive precedent. The specificity of the grant from Congress, however, would not necessarily override or negate other considerations.

(c) Agency Expertise. Pre-Chevron case law varied the degree of deference according to whether the issue was one that implicated agency "expertise." This idea is encountered less often in the realm of judicial precedent, but it is not unheard of. For example, courts of appeals will occasionally give extra deference to decisions of other circuits that have greater familiarity with the substantive body of law in question. ${ }^{182}$ And courts quite commonly defer to interpre-

179. The principal exception is the Rules Enabling Act, which authorizes the Supreme Court to adopt rules of civil procedure and evidence. 28 U.S.C. $\$ 2072$ (1988). This delegation, however, concerns matters of judicial self-governance, over which courts would presumably have inherent authority in the absence of a legislative delegation. See Thomas Merrill, The Common Law Powers of Federal Courts, 52 U. CHI. L. REV. 1, 46-47 (1985). Another arguable exception is the Sentencing Commission, on which three federal judges sit. In Mistretta v. United States, 488 U.S. 361 (1989), the Supreme Court held that it was constitutionally permissible for Congress to constitute the Sentencing Commission as part of the judicial branch, even though it exercises substantive rulemaking authority.

180. See Batterton v. Francis, 432 U.S. 416, 424-25 \& n.9 (1977); 1 DAVIS, supra note 6, at 421-22.

181. Some pre-Chevron cases suggested that interpretations adopted pursuant to general rulemaking authority were entitled to less weight than interpretations more specifically authorized by Congress. See, e.g., United States v. VogeI Fertilizer Co., 455 U.S. 16 (1982); Rowan Cos., Inc. v. United States, 452 U.S. 247,253 (1981). Other cases suggested that interpretations adopted pursuant to general rulemaking authority were no different from specific authorizations. See, e.g., FCC v. WNCN Listeners Guild, 450 U.S. 582, 594 (1981).

182. See City of Westfield v. Federal Power Comm'n, 551 F.2d 468 (1st Cir. 1977) (views of D.C. Circuit, which reviews great bulk of Federal Power Commission orders, carry great weight when case involving similar issue comes before other circuit); Watson v. Allen, 254 F.2d 342, 347 (D.C. Cir. 1958) ("substantial weight" given to views of Court of Customs and Patent Appeals "as to technical or highly specialized patent matters"). 
tations of state law or procedural law by other courts that have greater experience with these localized legal regimes. ${ }^{183}$

The notion that specialized competence warrants deference naturally plays a more prominent role in the executive precedent context because of the specialized nature of administrative agencies. Common sense suggests that the views of those with specialized knowledge about a subject are generally more valuable than the views of those without such knowledge. Because agencies are specialists, it follows that additional deference should be given to their judgments within the area of their specialization. Thus, pre-Chevron case law accorded extra deference to an agency's interpretations of the specific statute it was charged with administering, but did not give any special deference to other types of agency interpretations, such as constructions of common law terms, constitutional principles, or prior judicial precedents, ${ }^{184}$ or to interpretations of statutes the agency did not ordinarily administer. ${ }^{185}$ The executive precedent model would carry this general distinction forward, treating the presence or absence of specialized agency knowledge as one of the factors to be considered in determining the strength of agency precedent.

(d) Longstanding Interpretations. Pre-Chevron cases put great stress on whether an agency interpretation was longstanding and consistent. This has a direct analogue in practice regarding judicial precedent. Here too, the longevity of the precedent is clearly an important factor in determining how much weight it will be given. ${ }^{186}$ The case for giving greater weight to old precedents is based primarily on two considerations. First, the fact that an interpretation has survived for a long period of time is some evidence that it is sound, in the sense that it is workable. ${ }^{187}$ Unworkable interpretations generate discontent that may result in congressional overruling, or modification or repudiation by the court that initially offered the interpretation. The fact that none of this has occurred is circumstantial evidence that the interpretation does not impose undue costs on regulated entities or frustrate the basic objectives of the proponents of the legislation. ${ }^{188}$ Second, longstanding interpretations give rise to

183. See Bishop v. Wood, 426 U.S. 341, 345-46 n. 10 (1976) (Supreme Court defers to interpretation of state law adopted by lower federal courts that are "familiar with the intricacies and trends of local law and practice"); Panduit Corp. v. All States Plastic Mfg. Co., 744 F.2d 1564, 1574-75 (Fed. Cir. 1984) (Federal Circuit adopts policy of following law of regional circuits with respect to procedural questions).

184. See, e.g., Piper v. Chris-Craft Indus., Inc., 430 U.S. 1, 41 n.27 (1977); Texas Gas Transmission Corp. v. Shell Oil Co., 363 U.S. 263, 268-70 (1960); SEC v. Chenery Corp., 318 U.S. 80, 89 (1943).

185. See, e.g., NLRB v. Bildisco \& Bildisco, 465 U.S. 513, 529 n.9 (1984); Alaska S.S. Co. v. United States, 290 U.S. 256, 261-64 (1933).

186. See, e.g., California v. FERC, 110 S. Ct. 2024, 2029 (1990) (referring to "the deference this Court must accord to long-standing and well-entrenched decisions, especially those interpreting statutes that underlie complex regulatory regimes"); Square D Co. v. Niagara Frontier Tariff Bureau, Inc., 476 U.S. 409, $421-22,424$ (1986) (refusing to overrule precedent followed for six decades notwithstanding extensive changes in statutory framework and related doctrine).

187. See Commissioner v. Fink, 483 U.S. 89, $102-03$ (1987) (Stevens, J., dissenting).

188. Similar points have been advanced in the literature seeking to explain why common law rules tend to be efficient. See William M. Landes \& Richard A. Posner, Legal Precedent: A Theoretical and Empirical Analysis, 19 J. LAW \& ECON. 249 (1976); George L. Priest, The Common Law Process and the 
reliance interests that warrant judicial protection. One of the primary justifications for the practice of following judicial precedents is to promote stability in the legal system by protecting these reliance interests. ${ }^{189}$ Of course, the presumption in favor of old precedents is not irrefutable. Generally speaking, however, the longer and more consistently a precedent has been followed, the higher the burden is on the party seeking to overcome the precedent to explain why it is infirm..$^{190}$

Given these judicial understandings, it is not surprising that the duration of an executive interpretation is the most frequently encountered factor in the pre-Chevron case law (and for that matter in the post-Chevron cases as well). The rationale for giving weight to longstanding agency precedent is identical to that for giving weight to judicial precedent: age is indicative of soundness (in the sense of workability), and older interpretations generate reliance interests deserving protection. ${ }^{191}$ It is also true that longstanding agency precedent, like longstanding judicial precedent, can be overruled. Courts can accommodate the need for change by imposing a higher burden of explanation on an agency reversing its own longstanding precedent than otherwise would be the case. ${ }^{192}$

(e) Well-Reasoned Decisions. Beginning with Skidmore v. Swift \& Co., ${ }^{193}$ the Supreme Court's pre-Chevron cases also gave greater deference to "wellreasoned" agency decisions. In determining whether to follow nonbinding precedents in the judicial context, such as decisions of courts of coordinate jurisdiction, courts frequently consider how persuasive the reasoning of the other court is: whether it has considered all relevant arguments, supported the

Selection of Efficient Rules, 6 J. LEGAL STUD. 65 (1977); Paul H. Ruben, Why is the Common Law Efficient?, 6 J. LEGAL STUD. 51 (1977).

189. See United States v. Mason, 412 U.S. 391 (1973) (stare decisis requires that people rely on the Court's decisions and that they should not be penalized for such reliance); $c f$. Payne v. Tennessee, $111 \mathrm{~S}$. Ct. 2597, 2610 (1991) ("[Clonsiderations in favor of stare decisis are at their acme in cases involving property and contract rights, where reliance interests are involved.").

190. See Fink, 483 U.S. at 89, 103 (Stevens, J., dissenting); Westinghouse Elec. \& Mfg. Co. v. Formica Insulation Co., 266 U.S. 342 (1924) (Court will not lightly disturb rule settled by 45 years of judicial construction with respect to rights arising under patent law).

191. The need to protect reliance interests has long been recognized as an important reason to defer to longstanding executive interpretations. As the Court observed in one case:

[G]overnment is a practical affair intended for practical men. Both officers, law-makers and citizens naturally adjust themselves to any long-continued action of the Executive Department-on the presumption that unauthorized acts would not have been allowed to be so often repeated as to crystallize into a regular practice. That presumption is not reasoning in a circle but the basis of a wise and quieting rule that in determining the meaning of a statute or the existence of a power, weight shall be given to the usage itself-even when the validity of the practice is the subject of investigation.

United States v. Midwest Oil Co., 236 U.S. 459, $472-73$ (1915); see also Brewster v. Gage, 280 U.S. 327, 336 (1930); Logan v. Davis, 233 U.S. 613, 627 (1914); United States v. Burlington \& Mo. River R.R., 98 U.S. 334, 341 (1879).

192. See American Hosp. Ass'n v. NLRB, 111 S. Ct. 1539, 1546 (1991) ("Given the extensive notice and comment rulemaking conducted by the Board, its careful analysis of the comments that it received, and its well-reasoned justification for the new rule, we would not be troubled even if there were inconsistencies between the current rule and prior NLRB pronouncements."); SEC v. Chenery Corp., 318 U.S. 80 (1943). See generally STEPHEN G. BREYER \& RICHARD B. STEWART, ADMINISTRATTVE LAW AND REGULATORY POLICY 416-26 (2d ed. 1985).

193. 323 U.S. 134 (1944). 
conclusion with a thorough explanation, and so forth. ${ }^{194}$ This is perfectly sensible. Because the precedent of a coordinate tribunal is not binding, it must compete with the court's independent analysis of the issue. Although there is a general bias in favor of uniformity, and thus the precedent will be regarded as prima facie correct, a poorly reasoned precedent obviously commands less respect and requires that the second court dig more deeply in order to ascertain for itself what the correct answer should be.

The same pattern is followed in the executive precedent context. Here, the pre-Chevron case law could, if anything, have done more to emphasize the importance of careful agency reasoning. Where agency factfinding and policy judgments are concerned, courts have come to insist that agencies take a "hard look" at the relevant variables and options. ${ }^{195}$ There is no reason why the preference for rigor should hot extend to legal interpretations.

(f) Interagency Agreement. Pre-Chevron case law reduced the degree of deference where two agencies were in disagreement about the proper interpretation of a statute. This practice also makes sense if we think of deference as a form of following precedent. Where a court faces conflicting precedents from different jurisdictions, it is much less likely to defer to one of those interpretations than it would where the precedent from other jurisdictions is unanimous. ${ }^{196}$ Here too, we see how the executive precedent model can rationalize pre-Chevron practice and integrate it with general norms of judicial self-governance.

(g) Contemporaneous Interpretations. A particularly venerable pre-Chevron factor laid stress on whether the agency interpretation was contemporaneous with the enactment of the statute. Because courts are generally not active participants in the process of formulating legislation, the views of a contemporary court are not necessarily probative of the thinking of the drafters of a statute. There is, however, a more direct analogue in constitutional law: the idea that courts should give deference to the views of the first Congress with respect to the meaning of the Constitution. ${ }^{197}$ The views of the first Congress are thought to be especially revealing because so many of the members of that Congress were active participants in the framing and ratification of the Consti-

194. See, e.g., Richards v. Local 134, Int'1 Bhd. of Elec. Workers, 790 F.2d 633, 636 (7th Cir. 1986); City Stores Co. v. Lerner Shops of D.C., Inc., 410 F.2d 1010, 1014 (D.C. Cir. 1969); see also Oneida County Fair Bd. v. Smylie, 386 P.2d 374, 391 (Idaho 1963) (state supreme court will select and apply decisions from other jurisdictions that reflect soundest reasoning.)

195. The general tenets of the "hard look" doctrine have been said to be: (1) agencies must offer detailed explanations for their decisions; (2) they must explain departures from past practices; (3) they must allow effective participation by affected interests; and (4) they must give consideration to possible alternative measures. Cass R. Sunstein, Deregulation and the Hard Look Doctrine, 1983 SuP. CT. REV. 181-82. For examples of "hard look" review in the Supreme Court, see Bowen v. American Hosp. Ass'n, 476 U.S. 610, 627 (1986); Motor Vehicles Mfrs. Ass'n v. State Farm Mutual Auto Ins. Co., 463 U.S. 29, $41-44$ (1983); Baltimore Gas \& Elec. Co. v. National Resources Defense Council, 462 U.S. 87, 105-06 (1983).

196. See Vestal, supra note 158 , at 163-65. (1983).

197. See Bowsher v. Synar, 478 U.S. 714, 723-24 (1986); Marsh v. Chambers, 463 U.S. 783, 790 
tution, and thus presumably had special insight into the original understanding. In effect, the decisions of the first Congress are viewed as one form of legislative branch "precedent" entitled to deference by the courts.

The rationale for the contemporaneous construction factor in administrative law is similar to that in the constitutional context. It has been observed that agency officials are often "the draftsmen of the laws they are afterwards called upon to interpret." 198 Even if agency actors did not participate directly in the formulation of the legislation, their contemporaneous interpretation can be regarded as indicative of the prevailing views about policy, given that the administrative agency often shares the same assumptions that animate the legislature. ${ }^{199}$ Like its constitutional cousin, the administrative doctrine has somewhat limited value, and goes more to the judicial discernment of congressional intent than to ascertaining the "strength" of the executive precedent. Moreover, I suspect that many of the references to contemporary constructions, especially in the earlier cases, are synonyms for longstanding construction. Nevertheless, even when used in its correct signification, there is no harm in incorporating it as one factor in the decisional matrix, as long as its rationale is clearly perceived.

(h) Ratified Interpretations. Finally, pre-Chevron cases often placed weight on evidence that Congress had ratified the executive construction. The idea that interpretations are entitled to greater deference if they have been ratified by Congress also has a precise parallel in the world of judicial precedent. Congress is presumed to be aware of the way statutes have been interpreted by courts. If one court adopts a particular interpretation, and Congress later reenacts the statute without substantively changing the interpreted language, then it is presumed that Congress has approved the interpretation. ${ }^{200}$ The doctrine can be explained by a kind of "squeaky wheel" theory of the legislative process similar to that which underlies (in part) the longstanding interpretation factor. If the initial interpretation generates discontent-in the sense that it imposes large costs on particular interest groups-then we can presume that those groups will bring it to the attention of Congress; if Congress agrees, it will amend the statute to overturn the interpretation. By the same token, if Congress reenacts a statute after judicial interpretation without changing the language, that is some evidence that the interpretation has not generated great discontent.

Because the doctrine makes some rather heroic assumptions, it should be used with caution. One problem relates to the assumption that Congress is aware of judicial interpretations of statutes. This may be contrary to fact if the interpretation affects large and diffuse interests that have difficulty organizing

198. United States v. Moore, 95 U.S. 760,763 (1888).

199. See, e.g., SEC v. Sloan, 436 U.S. 103, 126 (1978) (Brennan, J., concurring).

200. See, e.g., Pierce v. Underwood, 487 U.S. 552, 566-68 (1988); Lorillard v. Pons, 434 U.S. 575, 580 (1978). See generally William N. Eskridge, Jr., Interpreting Legislative Inaction, 87 MiCH. L. REV. $67,70-84$ (1988). 
for legislative action. ${ }^{201}$ Another problem is presented by those cases that find congressional ratification based on the failure of Congress to enact proposed legislation. Legislative inaction is always inherently ambiguous and could reflect nothing more than a crowded legislative agenda. But as long as ratification is limited to cases where at least the relevant committees have been informed of an interpretation, and Congress reenacts the relevant legislation without change, it is probably a useful doctrine.

The administrative ratification doctrine-a staple of pre-Chevron case law-has exactly the same logic and limitations as the judicial ratification doctrine. Administrative interpretations can be just as important to interest groups as judicial interpretations, and we can expect that the interpretations that make well-organized interest groups unhappy will come to the attention of Congress. Thus, subject to the caveats noted about the judicial ratification version, congressional ratification is a permissible factor for courts to use in ascertaining the weight of executive precedent.

\section{The Post-Chevron Exceptions Under the Executive Precedent Model}

The executive precedent model also makes sense of some of the disputes over Chevron fundamentals that have erupted in recent years. In each case, the model suggests that there are sound reasons to deviate from the logic of Chevron.

(a) Interpretations Beyond Agency Authority. In Adams Fruit Co. v. Barrett ${ }^{202}$ the Court held that agency interpretations are entitled to no deference if they concern a topic that the agency has not been empowered to regulate. In effect, Adams Fruit carries Chevron's presumed delegation theory to its ultimate conclusion. Since the delegation of regulatory authority gives rise to the duty to defer, where there is no delegated power there is no deference.

Pre-Chevron case law was more refined. When an agency spoke about a matter as to which it had no power to regulate, its views were still entitled to consideration by courts, provided they bore other indicia that would entitle them to respect. This was the holding of Skidmore. ${ }^{203}$ The executive precedent model would adhere to this pre-Chevron understanding, rather than to Adams Fruit. If an agency's interpretation qualifies as executive precedent and has other attributes that suggest it is entitled to deference, there is no reason why it should not be given appropriate weight as a form of precedent. For example, agencies often have specialized knowledge about the operations of a particular industry and the way it is affected by a statutory scheme. If the agency has issued an interpretative regulation or policy statement that provides a reasoned

201. See Mancur Olson, The Logic of Collective Action (1971); Bruce A. Ackerman, Beyond Carolene Products, 98 HARV. L. REV. 713 (1985).

202. 494 U.S. $638,649-50$ (1990).

203. Skidmore v. Swift \& Co., 323 U.S. 134, 139-40 (1944). 
analysis of the way the statute should be read, its views should be entitled to some weight, even if does not have day-to-day regulatory authority over the matter in contention. Adams Fruit is the wooden product of a conceptual scheme that all too often forecloses potentially valuable lines of inquiry, and it should be rejected.

(b) Post hoc Rationalizations. In contrast, the Court's decision to exclude "post hoc rationalizations" of counsel from Chevron deference ${ }^{204}$ is not consistent with the logic of Chevron. As long as the question concerns a matter delegated to the agency, Chevron suggests it should not matter how or when the agency announces its interpretation.

The "post hoc rationalization" exception, however, conforms to pre-Chevron case law, ${ }^{205}$ and can be explained by the executive precedent model. As noted above, post hoc rationalizations are simply not "precedents." They are interpretations first advanced by an agency in its capacity as a party litigant, not in its capacity as an independent decisionmaker. Thus, any deference to agency views in this context would offend ideals of judicial impartiality.

(c) Canons of Construction. The Court has also suggested that certain canons of construction-most notably, the canon that interpretations of doubtful constitutionality are to be avoided-may trump the Chevron doctrine. ${ }^{206} \mathrm{Chev}$ ron itself supplies no rationale for such a holding. Under the executive precedent model, in contrast, courts may consult any traditional tool of interpretation in arriving at an assessment of the clarity of statutory meaning. Canons that serve as default rules in the absence of more direct evidence of congressional intent should not play a major part in this exercise. If there is no better means of resolving a question of interpretation than calling upon such a canon, then, as a general rule, the executive interpretation should not be set aside. On the other hand, canons grounded in considerations of constitutional law and structure ${ }^{207}$ may supply a stronger basis for overcoming executive precedent.

(d) Judicial Precedent. In Maislin Industries, U.S. v. Primary Steel, Inc., the Court held that an agency cannot change its mind about the meaning of a statute if by doing so it "casts doubt on [the Court's] prior interpretation" of the statute. ${ }^{203}$ This conclusion remains a mystery under Chevron, but makes perfect sense under the executive precedent model. It is useful here to return to the judicial analogy. Although one court of appeals should treat a decision of another court of appeals as prima facie correct, the precedent of the second

204. Bowen v. Georgetown Univ. Hosp., 488 U.S. 204, 212 (1988) (quoting Burlington Truck Lines v. United States, 371 U.S. 156, 168 (1968)).

205. See, e.g., SEC v. Sloan, 436 U.S. 103, 117-18 (1978); Investment Co. Inst. v. Camp, 401 U.S. 617, 628 (1971); SEC v. Chenery Corp., 318 U.S. 80, 87-88 (1943).

206. Edward J. DeBartolo Corp. v. Florida Gulf Coast Bldg. \& Constr. Trades Council, 485 U.S. 568 , 574-75 (1988).

207. See, e.g., Gregory v. Ashcroft, 111 S. Ct. 2395, 2403-06 (1991) (adopting canon that statute will not be construed to interfere with traditional state governmental functions absent clear congressional statement indicating intent that it be so applied).

208. Maislin Indus., U.S. v. Primary Steel, Inc., 110 S. Ct. 2759, 2770 (1990). 
court-however well reasoned and consistently followed - cannot overcome the force of the court's own precedent. ${ }^{209}$ Stare decisis prevails over the deference given to precedents of other circuits.

Similarly, an executive precedent cannot outweigh a directly applicable judicial precedent. Of course, the executive view may provide an occasion for the courts to reconsider their own precedent, just as contrary decisions from other circuits may often trigger en banc reconsideration by courts of appeals. ${ }^{210}$ But such a change at best constitutes an appeal to the discretion of the court to overrule its prior precedent under the criteria of stare decisis; it does not impose an obligation on the courts to change their views or even to engage in a reconsideration. Thus, the executive precedent renders the outcome in Maislin perfectly explicable.

(e) Decisions Implicating Agency Jurisdiction. In Mississippi Power \& Light Co. v. Mississippi ex rel. Moore, ${ }^{211}$ Justices Brennan and Scalia engaged in an inconclusive debate over whether an exception to Chevron should be created for interpretations that implicate the limits of an agency's jurisdiction. This issue is particularly ill suited to sweeping, either/or solutions. A rule precluding deference on issues that implicate an agency's jurisdiction would accomplish indirectly what Cardoza-Fonseca sought to do directly: it would eliminate any deference on "pure" questions of statutory interpretation. This is because almost any purely legal question will have implications for the scope of an agency's authority. At the same time, courts have long operated with a kind of unwritten understanding that deference to agency views is not appropriate, at least not to the same degree, where the agency view is likely to be influenced by institutional bias. ${ }^{212}$ For example, courts do not defer to agency views on whether agency decisions are judicially reviewable, whether agency action falls within the terms of the Federal Torts Claims Act, whether agencies are liable to pay attorney's fees, or whether agency documents must be disclosed under the Freedom of Information Act. ${ }^{213}$ For similar reasons, at least a lesser degree of deference may be warranted when an agency decides to regulate a new area: the decision to regulate may be motivated by designs for agency aggrandizement rather than by a disinterested assessment of statutory authority and appropriate policy.

The executive precedent model permits courts to give effect to concerns about institutional bias in determining whether deference is appropriate. In the

209. E.g., Federal Sav. \& Loan Ins. Corp. v. Bonfanti, 826 F.2d 1391, 1394 n.3 (5th Cir. 1987), vacated sub nom. Zohdi v. Federal Sav. \& Loan Ins. Corp., 490 U.S. 1001 (1989).

210. See FED. R. APP. P. 35.

211. 487 U.S. 354 (1988).

212. See Braun, supra note 106 , at 1005-07; Sunstein, supra note 4 , at 2101 .

213. See, e.g., United States v. Fausto, 484 U.S. 439 (1988) (judicial review); Pierce v. Underwood, 487 U.S. 552 (1988) (attorney's fees); CIA v. Sims, 47 I U.S. 159 (1985) (Freedom of Information Act); United States v. S.A. Empresa de Viacao Aerea Rio Grandense (Varig Airlines), 467 U.S. 797 (1984) (Federal Torts Claims Act). 
most egregious cases of agency bias-for example, where the issue is whether an agency decision is subject to judicial review-there may well be no executive precedent since the issue arises only when the agency is engaged in its role as a judicial litigant. In the more difficult case where an agency has concluded that its statutory mandate permits a new industry or activity to be regulated (or deregulated), the executive precedent model permits—as is appropriate-a more modulated response. The concern with possible agency bias justifies reducing the degree of deference without disregarding agency views and arguments altogether. In contrast, the rigid Chevron doctrine demands that courts either defer or not defer, permitting a court to disregard an agency's conclusions only if it can identify a clear statutory mandate that has been violated. Again, the more flexible approach better serves the separation of powers concerns furthered by the practice of independent judicial review.

All in all, the executive precedent model makes sense of a great deal of learning previously regarded as an unconnected hodgepodge of factors with no unifying theme or rationale. The persistence of these traditional factors in the face of an official doctrine that is hostile to their survival suggests that there is value in this conventional wisdom. The congruence between the executive precedent model and observations of conventional practice provides powerful support for the model's validity.

\section{Consequences for Judicial and Agency Performance}

Finally, it is important to give some consideration to the systemic effects that the executive precedent model might have relative to the Chevron model. Of course, in undertaking any such inquiry, one must bear in mind that the Chevron model operates quite differently in practice than it does on paper.

\section{Consequences for Courts}

Proponents of the Chevron doctrine are attracted almost exclusively by the prospect that its formal or rulelike qualities will confine judicial discretion. Restricting judicial discretion is thought to be desirable in this context for both instrinsic and extrinsic reasons.

The intrinsic reason is that restrictions on judicial discretion are thought to be necessary if we are to speak of courts as being bound by "law."214 Whatever the theoretical or practical failings of Chevron, or its discontinuities with past (and present) judicial practice, it at least has the appearance of a legal rule rather than an "all things considered" standard. Justice Scalia, probably

214. See Antonin Scalia, The Rule of Law as a Law of Rules, 56 U. CHI. L. REV. 1175 (1989). For a general discussion, see Frederick Schauer, Formalism, 97 YALE L.J. 509 (1988). 
the foremost champion of the Chevron doctrine, ${ }^{215}$ is clearly attracted to this feature of Chevron. From this perspective, the executive precedent model is not sufficiently rulelike: it imports so many factors that the practice of deference would degenerate into an ad hoc inquiry that would allow courts to reach any result they wanted to. Moreover, with so many factors from which to choose, effective review or oversight by the Supreme Court would be impossible. ${ }^{216}$ While there is clearly some merit to this criticism, I would offer several points by way of response.

First, although my proposed executive precedent model is clearly more open textured than Chevron, I do not think that it can fairly be described as "lawless." Unlike the pre-Chevron regime that it resembles, the executive precedent model endorses neither ad hockery nor an open-ended "list of factors" approach. Instead, it offers a theory that explains the respective roles of the executive and judicial branches, tells us which deference factors are relevant and why, and provides an account, in general terms at least, of how the court is to consider the executive view relative to its own assessment of the interpretative question. The model may be complex-too complex to be reduced to a simple Chevron-like formula-but it is not "unprincipled." Nor can it be said that the model prescribes an ad hoc balancing test. Such tests require courts to engage in a "head-to-head comparison" of competing interests. ${ }^{217}$ The executive precedent model, in contrast, is grounded in analogical reasoning, whereby various factors become relevant in determining whether a particular case approximates a particular paradigm. In this sense, it is simply a variant on what is perhaps the most universal tool of legal reasoning. ${ }^{218}$

Second, to a considerable extent, the case for legal formalism is much stronger where rules of primary behavior are concerned than it is when we are dealing with rules of legal method. When courts adopt "all things considered" tests for the governance of primary behavior, serious questions can be raised about whether similarly situated persons are in fact treated alike. ${ }^{219}$ But it is hard to see how the equality norm is offended, at least to anything approaching the same degree, when an issue of statutory interpretation is resolved in one case using one set of interpretative tools and a different issue of statutory interpretation is resolved in another case using other interpretative tools. As long as the outcome of each exercise of statutory interpretation is applied

215. See NLRB v. United Food \& Commercial Workers Union, 484 U.S. 112, 133-34 (1987) (Scalia, J., concurring) (applauding the Court for abandoning the limiting approach of Cardoza-Fonseca); Scalia, supra note 39.

216. See Scalia, supra note 214 , at $1178-82$ (criticizing multifactor tests for transforming questions of law into questions of fact and for insulating lower courts from effective appellate review). (1987).

217. T. Alexander Aleinikoff, Constitutional Law in the Age of Balancing, 96 YALE L.J. 943, 945

218. See EdWARd H. LeVI, AN INTRODUCTION to Legal REASONING 1-2 (1949).

219. Scalia, supra note 214 , at 1178 . 
consistently, the individuals primarily affected will generally perceive that they are being treated equally.

Third, the claim that Chevron allows the Supreme Court to control the behavior of lower courts, whereas the executive precedent model would not, cannot be based on the Chevron doctrine as we currently know it-where the two-step framework is ignored as often as it is followed, and when followed, is applied in several different versions. But even if the Court were to adhere to a "pure" version of Chevron, there would still be ample opportunities for manipulation, most prominently through spurious identifications of "specific intentions" or "plain" statutory meanings. Thus, even though Chevron is more formalistic than the executive precedent model, it too cannot constrain willfulness in the lower courts. To be sure, there is no basis for believing that the executive precedent model would impose greater constraints on lower courts than would a rigorously and consistently applied Chevron. But I do think it likely that the decision to defer under the executive precedent model would be made in a more candid manner, with more revealing reasons given in support of judicial outcomes. The relevant choice, therefore, may not be between constrained and unconstrained judicial decisions, but between more or less judicial candor.

Finally, I seriously doubt whether it would ever be possible to decide all deference questions without being drawn into some type of contextual or multivariate inquiry, call it "pragmatism" or "practical reasoning" or whatever. ${ }^{220}$ As Judge Stephen Breyer has observed, "there are too many different types of circumstances, including different statutes, different kinds of application, different substantive regulatory or administrative problems, and different legal postures in which cases arrive, to allow 'proper' judicial attitudes about questions of law to be reduced to any single simple verbal formula."221 The fact that the Court is now creating various ad hoc exceptions and alternative formulations of the Chevron doctrine suggests the beginnings of a process whereby the apparent simplicity of Chevron is tempered with a variety of qualifying rules. When we start with the two-step Chevron framework and then create these exceptions, we end up with a crazy patchwork that lacks any internal coherence. The executive precedent model, by admitting a wider variety of variables in a more contextualized relationship at the outset, can avoid the need for this kind of improvised structure.

The extrinsic reason for wanting to constrain judicial discretion by formal rules is that this would enhance the ability of agencies to change the law. It is no accident that many of the principal defenders of Chevron-including Justice

220. See RICHARD A. POSNER, THE PROBLEMS OF JURISPRUDENCE 286-309 (1990) (urging pragmatic approach to statutory interpretation); William N. Eskridge, Jr. \& Philip P. Frickey, Statutory Interpretation as Practical Reasoning, 42 STAN. L. REV. 319 (1990).

221. Breyer, supra note 175 , at 373 . 
Scalia and Judges Starr and Silberman ${ }^{222}$-all served in the first Reagan Administration, when an aggressively conservative executive branch sought widespread change in the law and encountered resistance from both Congress and the judiciary. These defenders endorse Chevron as a tool for translating the electoral mandate of the President into legal reform, thereby overcoming the resistance of the other two branches of government.

This rationale for Chevron, however, is obviously limited to a particular set of historical circumstances-circumstances that have already been at least in part superseded by the appointment of increasing numbers of federal judges by Presidents Reagan and Bush. What is needed is a formula that strikes a more enduring balance between executive, legislative, and judicial perspectives, and between the forces of change and stability.

The executive precedent model envisions a larger role for the judiciary than does the original version of Chevron. However, as previously indicated, this larger role is necessary if courts are to perform their traditional function of checking administrative abuses of power. ${ }^{223}$ On the other hand, I do not think that the discretionary nature of the executive precedent model would cause courts to engage in wholesale substitution of judgment for agency interpretations. Other rules grounded in judicial self-governance, most prominently the understanding that courts must follow precedents of superior courts and the doctrine of stare decisis, exert a powerful influence over the manner in which courts resolve legal controversies. There is no reason why the deference doctrine, understood as a form of respect given to legal interpretations by another branch of government of coordinate constitutional status, should not also exert an important influence over judicial behavior.

To be sure, by stressing the importance of reliance factors such as longstanding and consistent agency interpretation, contemporaneous interpretation, and congressional ratification, the executive precedent model is also more resistant to rapid change in law than is Chevron. But again, I think this is healthy. Chevron is a doctrine for Jacobeans: the results of a single Presidential election are a sufficient cause for wholesale modifications in the law, with no offsetting incentive for stability or protection of reliance interests. Surely, it is rather odd for Whiggish conservatives like Justice Scalia — who speak glowingly of legal formalism because it promotes predictability in the law, ${ }^{224}$ and who eloquently defend a strict separation of powers in order to prevent undue concentrations of power that pose a threat to liberty and private rights ${ }^{225}$ - to endorse Jacobean measures.

222. See Scalia, supra note 39; Silberman, supra note 44; Starr, supra note 34; see also Judicial Review of Administrative Action in a Conservative Era, 39 ADMIN. L. REV. 353 (1987) (panel discussion including Judge Starr and Richard Willard, a Justice Department official in the Reagan Administration).

223. See supra text accompanying notes $117-22$.

224. Scalia, supra note 214 , at 1179.

225. Morrison v. Olson, 487 U.S. 654, 697 (1988) (Scalia, J., dissenting). 
The executive precedent model would strike a better balance between stability and change. By giving greater deference to longstanding, contemporaneous, and ratified agency interpretations, it would introduce a bias in favor of stability, and would give a measure of protection to the reliance interests that these interpretations have generated. ${ }^{226}$ But this model would not rule out change, provided that the reasons for change are clearly articulated and the new interpretation is consistent with the statutory framework. Thus, it would not "freeze" the law or preclude legal development in response to changed perceptions of policy, whether caused by Presidential elections or otherwise.

\section{Consequences for Agencies}

When we turn from the consequences for judicial behavior to the effects on agency behavior, the balance sheet wholly favors the executive precedent model. The Chevron framework essentially provides no incentives for agency behavior. It focuses at both steps one and two almost exclusively on variables relevant only to judicial functioning. The executive precedent model, in contrast, pays equal attention to the caliber and quality of the agency's precedent, and by making the weight of the agency's precedent relevant to the decision to defer, provides incentives for agencies to engage in certain types of behavior rather than others. Three incentives, in particular, would be introduced by the executive precedent approach.

The first is the incentive to maintain a consistent position over time. Consistency is desirable insofar as it promotes equality of treatment between similarly situated parties, protects reliance interests, and renders administrative action more predictable, thereby allowing private parties to engage in meaningful planning. ${ }^{227}$ Consistency may also reduce "rent seeking" in the form of expenditures of resources designed to influence agencies to change their interpretations of the law. ${ }^{228}$

On the other hand, a rigid rule of "first in time, first in right" would eliminate one of the advantages of using agencies to implement law: the possibility of modifying policy over time as experience accumulates and conditions and public perceptions change. And a rule making the first interpretation controlling might induce excessive expenditures to influence the initial construction of the law. The executive precedent model strikes an appropriate

226. See Monaghan, supra note 147, at 751-52 (practice of judicial adherence to precedent fosters conservative values).

227. It is no coincidence that these are some of the same values served by formal rules of law. See Scalia, supra note 39. For traditional administrative law statements endorsing greater agency consistency, see, e.g., BREYER \& STEWART, supra note 192: 4 DAVIS, supra note 6, $\$ 20: 11$.

228. This point was suggested to me by my colleague Keith Hylton. See Keith Hylton, Doctrinal Efficiency and Labor Law (Aug. 1991) (unpublished manuscript on file with author) (discussing possible rent-seeking responses to frequent changes in National Labor Relations Board doctrine). 
balance between these concerns by demanding either agency consistency or a persuasive explanation for change as a condition for deference.

The second relevant incentive is the attempt to strive for harmony among different agencies. It is always difficult to maintain coherence in our sprawling bureaucratic state. Various mechanisms for centralized control exist, including preclearance of regulations by the Office of Management and Budget ${ }^{229}$ and preclearance of judicial appeals by the Solicitor General. ${ }^{230}$ But the centripetal forces tend always to overpower the centrifugal. The idea that agency interpretations that conflict with other agency interpretations will lose a measure of judicial deference adds another small incentive for internal coherence.

The third is the incentive to provide reasoned explanations for statutory interpretations. It is "anomalous" 231 that agency factfinding and policymaking is today subject to searching review under the "hard look" doctrine, which requires a careful consideration of relevant factors and an answer to prominent objections by affected parties. ${ }^{232}$ Under Chevron, however, agency interpretations of law are subject to automatic deference unless the court finds that the matter has been clearly resolved by Congress. Paradoxically, therefore, official doctrine requires more searching judicial review on questions of fact and policy-where agencies are traditionally thought to enjoy a comparative advantange-than on questions of law, where the traditional view was that courts held the edge. ${ }^{233}$

One of the promising features of the executive precedent model is that it would tend to incorporate some of the features of "hard look" review into the process of considering whether to give deference to executive interpretations of statutes. The strength of an agency precedent would to a significant extent be a function of how carefully the agency considered the question of interpretation, responded to objections, and offered reasons in support of the interpretation adopted. In effect, an agency that has given a "hard look" at a question of interpretation will be entitled to greater deference than an agency that has given only cursory consideration to the issue.

\section{Consequences for Congress}

Finally, it is worth speculating briefly about what sorts of incentives a rigorously enforced Chevron would create for Congress. It is unlikely that Congress would stand idly by in response to a major realignment in the division of powers that enhanced the executive branch's ability to institute policy

229. As required by Exec. Order No. 12,291, 3 C.F.R. 127. (1981), reprinted in 5 U.S.C. § 601 (1982).

See Christopher C. DeMuth \& Douglas H. Ginsburg, White House Review of Agency Rulemaking, 99 HARV.

L. REV. 1075 (1986).

230. See 28 C.F.R. $\$ 0.20$ (b) (1991).

231. Breyer, supra note 175 , at 397 .

232. See sources cited supra note 195 .

233. See Diver, supra note 11 , at 574 . 
changes and minimized the role of the courts in checking administrative abuses. One would expect some combination of three responses from Congress, none of which in my view would be desirable.

Perhaps the most straightforward congressional response would be to enact longer and more detailed statutes. ${ }^{234}$ If the only things courts will enforce are specific directives, then Congress would try to supply as many specific directives as possible. While some might hail this development as a healthy reassertion of the "legislative power" by its constitutional instrument, ${ }^{235}$ there is reason to believe that an upsurge in the specificity of legislation would lead to bad policy ${ }^{236}$ and more influence by private interest groups. ${ }^{237}$ There can be little doubt that it would add to the complexity-and incomprehensibility-of the legal system.

Another possible congressional response would be to seek greater influence over administrative agencies. This might take the form of direct restrictions on Presidential authority over agency heads. More likely, it would manifest itself in the form of more intensive oversight hearings and contacts between congressional staff and agency personnel. ${ }^{238}$ The result, again, would be an erosion of coherence and greater interest group influence..$^{239}$

Third, Congress might attempt to overrule Chevron directly, perhaps by enacting some form of the Bumpers Amendment. ${ }^{240}$ As previously indicated, I think that Congress has the constitutional power to direct courts to adandon the Chevron approach. But such a response would very likely take the form of an overreaction-as the Bumpers Amendment surely would be-and at the very least would create a troubling precedent for congressional intervention in matters traditionally left to evolutionary judicial development.

Of course, the chance of these responses occurring will be reduced if the Court continues to create exceptions to the Chevron doctrine and to ignore it altogether. Nevertheless, there can be little doubt that the executive precedent approach-which is more consistent with historic practice and promises to result in a more balanced judicial role-would provide even greater assurances against undesirable congressional reactions.

234. Hertz, supra note 113 , at 1675.

235. See, e.g., JOHN H. ELY, DEMOCRACY AND DISTRUST 131-33 (1980) (criticizing excessive delegation of legislative authority on democratic theory grounds); J. Skelly Wright, Beyond Discretionary Justice, 81 YALE L.J. 575, 584-86 (1972) (urging revival of nondelegation doctrine).

236. See Bruce A. Ackerman \& William T. Hassler, Clean COALDirTy AIR (1981) (arguing that highly detailed provisions in 1977 Clean Air Act Amendments impeded EPA's ability to develop effective policy).

237. See Jerry L. Mashaw, Prodelegation: Why Administrators Should Make Political Decisions, 1 J.L. ECON. \& ORGANIZATION 81 (1985) (public choice theory suggests that interest groups will have greater influence in legislative arena than in administrative arena).

238. See Lazarus, supra note 118.

239. See Harold H. Bruff, Legislative Formality, Administrative Rationality, 63 TEX. L. REV. 207 (1984)

(discussing interest group influence exerted through congressional oversight process).

240. See supra note 111. 


\section{CONCLUSION}

From the perspective of this Article, the long controversy over judicial deference to administrative interpretations of statutes can be seen as a rivalry between two competing models: the mandatory deference model and the discretionary deference model. The rivalry has been largely unconscious because the assumptions of the mandatory deference model are often unstated, and the theoretical basis for the discretionary deference model has never been previously articulated. Still, we can see these ideas struggling for dominance in judicial practice.

In the pre-Chevron era, the two models coexisted uneasily. Courts applied the mandatory deference model to interpretations backed by express delegations of regulatory authority from Congress. But in the absence of an express delegation, they applied something that in retrospect looks very much like the discretionary deference model-examining various contextual factors that could be applied just as easily to a precedent of a court of coordinate jurisdiction as to the construction of an executive branch agency. The Chevron era on paper represents a rejection of the discretionary approach and an embrace of a pure mandatory regime. Now, however, the realm of mandatory deference has vastly expanded to include a presumption of delegation in all cases where a federal statute is ambiguous or unclear. As we have seen, however, in practice the discretionary approach has lived on, in the shadows of Chevron, and in considerable tension with its expanded delegation theory.

Chevron's many failings are largely those of the mandatory deference model that it incorporates. Although the idea of express delegation is straightforward enough, the concept of an implied delegation of interpretative authority is difficult to characterize as a congressional command. The focus on delegation also makes the decision about whether to defer subordinate to the resolution of a question of judicial interpretation: Did Congress (constructively) delegate, or did it not? In this fashion, consideration of the executive view becomes ensnared in controversies over the legitimate scope of judicial interpretation. Finally, the idea of delegation requires that deference be viewed in either/or terms: either Congress delegated authority, or it did not; no intermediate possibilities make sense. The either/or nature of the mandatory deference theory based on delegated power pushes the doctrine toward extremes of either too little or too much deference.

I have argued that a better solution to the uneasy mixture of the pre-Chevron period would have been to move to a pure discretionary regime, what I have called the executive precedent model. The idea of delegation would not disappear in such a regime. It would simply revert to its original scope of express delegation, and it would become one of several factors that courts would examine in determining the "strength" of an executive precedent. Because the practice of deference under the executive precedent model is grounded 
in a conception of the judicial power rather than in a fiction of delegation, it avoids the major theoretical failings of the Chevron doctrine. In addition, it allows courts to consider various attributes of the executive decision that seem undeniably relevant to the question of how much weight it should be given: such as whether the agency's interpretation is supported by careful reasoning, whether its interpretation has generated reliance interests that should be protected, and whether its construction has been approved by Congress. The executive precedent model also permits a flexible response to the question of deference, allowing courts to give various degrees of deference to executive interpretations, depending on the strength of the contextual factors involved and on the court's conviction about the clarity of the statute as an original matter.

Like its close cousin, the doctrine of judicial precedent, the model of executive precedent does not admit of easy or pat answers. But this does not mean it has nothing to say about what variables are relevant to its operation and why they are significant. In this respect, one of the significant benefits of the executive precedent model is that it might teach us something about the practice of following judicial precedent, of which legal academics have unfortunately had far too little to say. 


\section{APPENDIX}

Agency Deference Cases in the Supreme Court

1981-1990 Terms

$\begin{array}{ccccc} & \text { Agency } & \text { Chevron } & \text { Step 1 } & \\ \text { Case } & \text { Interpretion } & \text { Framework } & \text { or } & \text { Traditional } \\ \text { Accepted? } & \text { Followed? } & \text { Step 2 } & \text { Factors }\end{array}$

1. Pauley v. Bethenergy Mines, Inc., 111 S. Ct. 2524 (1991)

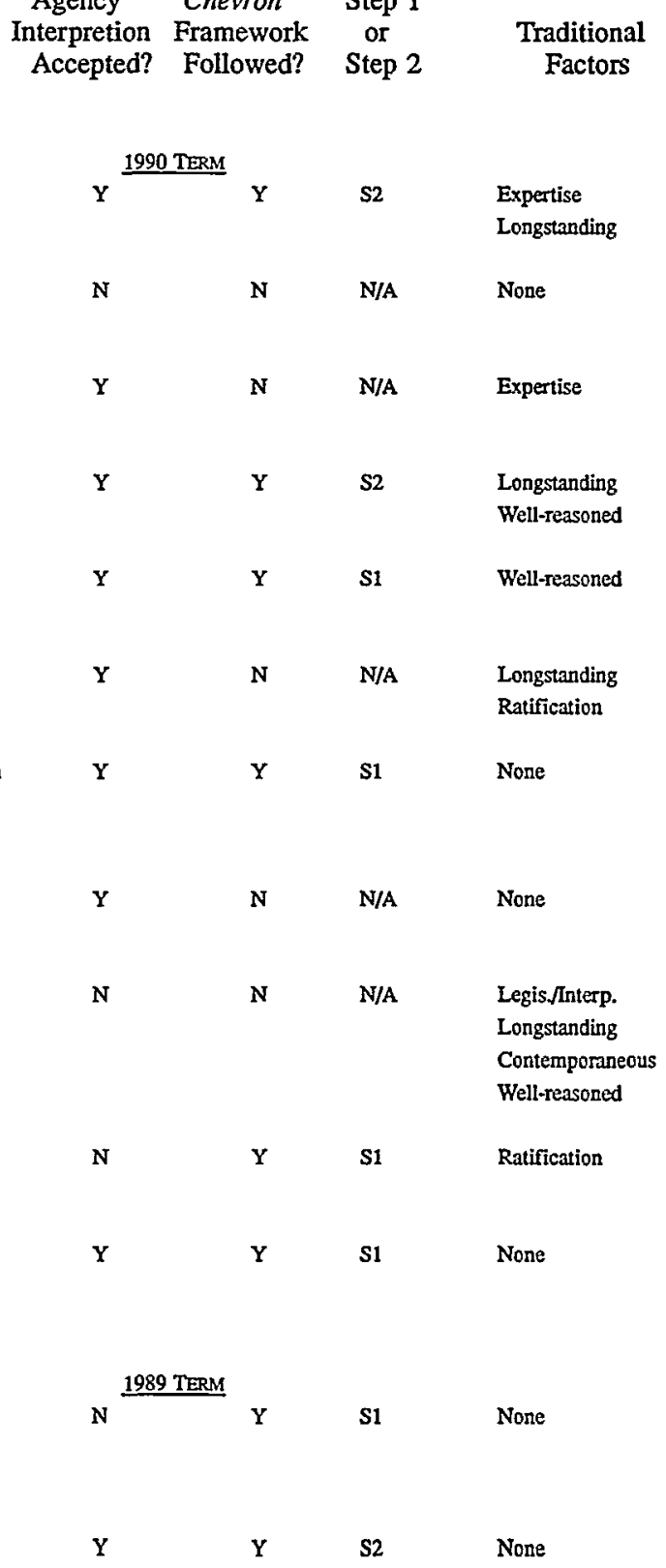

2. Gregory v. Ashcroft, 111 S. Ct. 2395 (1991)

3. Litton Fin. Printing Div. v. NLRB, 111 S. C. 2215 (1991)

4. Rust v. Sullivan, 111 S. Ct. 1759 (1991)

5. American Hosp. Ass'n v. NLRB, 111 S. Ct. 1539 (1991)

6. Cottage Sav. Ass'n v. Commissioner, 111 S. Ct. 1503 (1991)

7. Norfolk \& Western Ry. Co. v. American Train Dispatchers Ass'n, 111 S. Ct 1156 (1991)

8. International Union, UAW v. Johnson Controls, Inc., 111 S. Ct. 1196 (1991)

9. EEOC v. Arabian Am. Oil Co., 111 S. Ct. 1227 (1991)

10. Demarest v. Manspeaker, 111 S. Ct. 599 (1991)

11. Mobil Oil Exploration \& Producing Southeast Inc. v. United Dist. Cos., 111 S. Ct. 615 (1991)

12. Maislin Indus., U.S. v. Primary Steel, Inc., 110 S. Ct. 2759 (1990)

13. Pension Benefit Guar. Corp. v. LTV Corp., 110 S. Ct. 2668 (1990) 
14. Sullivan v. Stroop,

$Y$

110 S. C. 2499 (1990)

15. Fort Stewart Sch. v. Federal Labor

Relations Auth., 495 U.S. 641 (1990)

$\mathbf{Y}$

$\mathbf{Y}$

SI

None

16. Davis v. United States,

$\mathbf{Y}$

495 U.S. 472 (1990)

17. Department of Treasury v. Federal

Labor Relations Auth., 494 U.S. 922 (1990)

18. NLRB v. Curtin Matheson Scientific, Inc., 494 U.S. 775 (1990)

19. Adams Fruit Co. v. Barrett, 494 U.S. 638 (1990)

20. Crandon v. United States, 494 U.S. 152 (1990)

21. Sullivan v. Everhart, 494 U.S. 26 (1990)

22. Dole v. United Steelworkers, 494 U.S. 26 (1990)

23. Sullivan v. Zebley, 493 U.S. 521 (1990)

24. United States v. Goodyear Tire \& Rubber Co., 493 U.S. 132 (1990)

25. Chesapeake \& Oh. Ry. Co. v. Schwalb, 493 U.S. 40 (1990)

26. Public Employees Retirement Sys. v. Betts, 492 U.S. 158 (1989)

27. Public Citizen v. United States Dept. of Justice, 491 U.S. 440 (1989)

28. Mead Corp. v. Tilley, 490 U.S. 714 (1989)

29. Robertson v. Methow Valley Citizens Council, 490 U.S. 332 (1989)

30. Marsh v. Oregon Natural Resources Council, 490 U.S. 360 (1989)

31. Massachusetts v. Morash, 490 U.S. 107 (1989)

32. Coit Independence Joint Venture v. Federal Sav. \& Loans Ins. Corp., 489 U.S. 561 (1989) 
33. Bowen v. Georgetown Univ. Hosp.,

N 488 U.S. 204 (1989)

34. Pittston Coal Group v. Sebben,

488 U.S. 105 (1989) *

$\mathrm{N}$

$\mathbf{N}$

N/A

Longstanding

35. Communications Workers $v$. Beck, 487 U.S. 735 (1988)

36. Mississippi Power \& Light Co. v. Mississippi $\quad \mathrm{Y}$ ex rel. Moore, 487 U.S. 354 (1988)

37. Huffman v. Westem Nuclear, Inc., 486 U.S. 663 (1988)

$\mathbf{Y}$$$
\text { N }
$$

N/A

None

38. K Mart Corp. v. Cartier, Ine., 486 U.S. $281(1988)^{241}$

$\mathbf{Y} \mathbf{N}$

$$
\text { N }
$$

N/A

Post hoc

rationalization

39. FERC v. Martin Exploration

$\mathbf{Y}$

Management Co.

486 U.S. 204 (1988)

40. EEOC v. Commercial Office Prods. Co., Y 486 U.S. 107 (1988)

41. Edward J. DeBartolo Corp. v. Florida $\mathbf{N}$ Gulf Coast BIdg. \& Constr. Trades Council, 485 U.S. 568 (1988)

42. Regents of the Univ. of Cal. v.

$$
\mathbf{Y}
$$

$$
\mathbf{Y}
$$

S2/S1

None

Public Employment Relations Bd., 485 U.S. 589 (1988)

43. Traynor v. Tumage, 485 U.S. 535 (1988)

$\mathbf{Y}$

N

N/A

Longstanding Ratification

44. Federal Labor Relations Auth. v. N Aberdeen Proving Ground, 485 U.S. 409 (1988)

45. Bethesda Hosp. Ass'n v. Bowen, 485 U.S. 399 (1988)

$N$

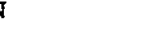

46. Etsi Pipeline Project v. Missouri, 484 U.S. 495 (1988)

$\begin{array}{llll}N & Y & \$ & \text { None }\end{array}$

47. Honig v. Doe, 484 U.S. 305 (1988)

$\mathbf{Y} \quad \mathbf{S} 2$

None

48. NLRB v. United Food \& Commercial

$\mathbf{Y}$

$\mathbf{Y}$

$\$ 2$

Longstanding Workers Union, Local 23, 484 U.S. 112 (1987)

49. Utah Div, of State Lands y 1986 TERM United States, 482 U.S. 193 (1987)

N N N/A None

241. For purposes of tabulation, this case has been counted as " $Y$ " and "S2." 
50. Bowen v. Yuckert, 482 U.S. 137 (1987)

51 Fall River Dyeing \& Finishing Corp. v. NLRB, 482 U.S. 27 (1987)

52. NLRB v. International Bhd. of Elec. Workers, Local 340, 481 U.S. 573 (1987)

53. Lukhard v. Reed, 481 U.S. 368 (1987)

54. INS v. Cardoza-Fonseca, 480 U.S. 421 (1987)

55. Clarke v. Securities Indus. Ass'n, 479 U.S. 388 (1987)

56. Wright v. City Of Roanoke

Redev. \& Hous. Auth., 479 U.S. 418 (1987)

57. Ansonia Bd. of Educ. v. Philbrook, 479 U.S. 60 (1986)

58. Commodity Futures Trading Comm'n v. Schor, 478 U.S. 833 (1986)

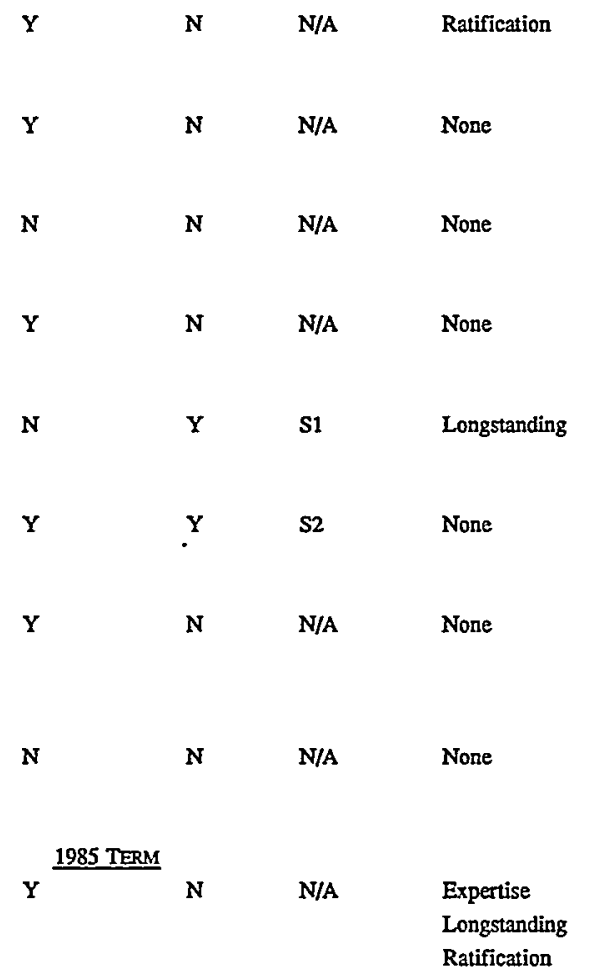

59. Local 28 of Sheet Metal Workers' Int'l Ass'n v. EEOC, 478 U.S. 421 (1986)

60. Japan Whaling Ass'n v. American Cetzcean Soc'y, 478 U.S. 221 (1986)

$\mathbf{Y}$

61. United States Dep't Of Transp. v. Paralyzed Veterans of Am., 477 U.S. 597 (1986)

62. Aukins v. Rivera, 477 U.S. 154 (1986)

63. Meritor Sav. Bank v. Vinson, 477 U.S. 57 (1986)

64. Young v. Community Nutrition Inst., 476 U.S. 974 (1980)

65. Bowen v. American Hosp. Ass'n, 476 U.S. 610 (1986)

66. FTC v. Indiana Fed'n of Dentists, 476 U.S. 447 (1986)

67. FDIC v. Philadelphia Gear Corp.,

476 U.S. 426 (1986)

$\mathbf{Y}$

$\mathbf{Y}$

N N/A

Longstanding

Contemporaneous

$\mathbf{Y}$

$\mathbf{Y}$

$\$ 2$

None

$\mathrm{Y} \quad \mathrm{S} 1$

Longstanding

N

$\mathbf{Y}$

N N/A None

$\mathbf{Y}$

N N/A Longstanding

Longstanding Ratification

None

Ratification 
68. United States v. City of Fulton,

$\mathbf{Y}$

$$
\mathbf{Y}
$$

S2

None

69. NLRB v. Financial Inst. Employees,

N

N

N/A

None

Local 1182,

475 U.S. 192 (1986)

70. Board of Governors of the Fed.

Reserve Sys. v. Dimension Fin. Corp.,

N

Y S1

None

474 U.S. 361 (1986)

71. United States v. Riverside

Bayview Homes, Inc.,

474 U.S. 121 (1985)

72. Pattern Makers' League of $\mathrm{N}$. Am. v. NLRB, 473 U.S. 95 (1985)

$$
\text { Y }
$$

$$
\mathbf{Y}
$$

S2

Ratification

73. Jean v. Nelson, 472 U.S. 846 (1985)

74. Comelius v. Nutt. 472 U.S. 648 (1985)

75. Central States S.E. \& S.W. Areas Pension Fund v. Central Transp., Inc., 472 U.S. 559 (1985)

76. Western Air Lines v. Criswell, 472 U.S. 400 (1985)

77. Mountain States Tel. \& Tel. Co. v. Pueblo of Santo Ana, 472 U.S. 237 (1985)

78. Lowe v. SEC, 472 U.S. 181 (1985)

$\mathbf{Y}$

\section{$N$}

Expertise

Longstanding

$\mathbf{Y}$

N

N/A

None

$\mathbf{Y}$

$\mathbf{N}$

N/A

None

$\mathbf{Y}$

N

N/A

None

$\mathbf{Y}$

N

N/A

Longstanding

$\mathbf{Y}$

$\mathbf{N}$

N/A

Longstanding

Contemporaneous

79. Connecticut Dep't of Income Maintenance v. Heckler,

471 U.S. 524 (1985)

80. INS v. Rios-Pineda, 471 U.S. 444 (1985)

81. Tony \& Susan Alamo Found. v. Secretary of Labor, 471 U.S. 290 (1985)

82. United States v. Locke, 471 U.S. 84 (1985)

83. Bennett v. Kentucky Dep't of Educ., 470 U.S. 656 (1985)

84. Heckler v. Turnet, 470 U.S. 184 (1985)

85. NAACP v. Hampton County Election Comm'n, 470 U.S. 166 (1985) 
86. Chemical Mírs. Ass'n v.

National Resources Defense Council 470 U.S. 116 (1985)

87. NLRB v. Action Automotive, Inc., 469 U.S. 490 (1985)

88. Alexander y. Choate, 469 U.S. 287 (1985)

89. Lawrence County v. Lead-Deadwood Sch. Dist., 469 U.S. 256 (1985)

90. United States v. Boyle, 469 U.S. 241 (1985)

91. Irving Indep. Sch. Dist. v. Tatro, 468 U.S. 883 (1984)

92. Securities Indus. Ass'n v. Board of Governors of Fed. Reserve Sys., 468 U.S. 207 (1984)

93. Securities Indus. Ass'n v. Board of Governors of Fed. Reserve Sys., 468 U.S. 137 (1984)

94. Sure-tan, Inc. v. NLRB, 467 U.S. 883 (1984)

95. Chevron U.S.A., Inc. v. National Resources Defense Council 467 U.S. 837 (1984)

96. United States v. Morton, 467 U.S. 822 (1984)

97. SEC v. Jerry T. O'Brien, Inc.. 467 U.S. 735 (1984)

98. Capital Cities Cable, Inc. v. Crisp, 467 U.S. 691 (1984)

99. Aluminum Co. of Am. v. Central Lincoln Peoples' Utij. Dist., 467 U.S. 380 (1984)

100. ICC v. American Trucking Ass'ns, Ine., 467 U.S. 354 (1984)

101. Escondido Mut. Water Co. v. La Jolla Band of Mission Indians, 466 U.S. 765 (1984)

102. NLRB v. City Disposal Sys., Inc., 465 U.S. 822 (1984)

\begin{tabular}{|c|c|c|c|}
\hline $\mathrm{Y}$ & $\mathrm{N}$ & N/A & None \\
\hline $\mathbf{Y}$ & $\mathbf{N}$ & N/A & None \\
\hline $\mathbf{Y}$ & $N$ & N/A & None \\
\hline $\mathbf{Y}$ & $\mathrm{N}$ & N/A & None \\
\hline \multicolumn{4}{|c|}{$1983 \mathrm{Term}$} \\
\hline $\mathrm{Y}$ & N/A & N/A & None \\
\hline $\mathbf{Y}$ & N/A & N/A & $\begin{array}{l}\text { Longstanding } \\
\text { Legis.Interp. }\end{array}$ \\
\hline $\mathbf{N}$ & $\mathbf{N}$ & N/A & $\begin{array}{l}\text { Longstanding } \\
\text { Post hoc } \\
\text { rationalization }\end{array}$ \\
\hline $\mathrm{Y}$ & N/A & N/A & None \\
\hline $\mathrm{Y}$ & $\mathrm{Y}$ & S2 & Expertise \\
\hline $\mathbf{Y}$ & N/A & N/A & Legis./Interp. \\
\hline $\mathbf{Y}$ & N/A & N/A & $\begin{array}{l}\text { Longstanding } \\
\text { Ratification }\end{array}$ \\
\hline $\mathrm{Y}$ & N/A & N/A & None \\
\hline $\mathbf{Y}$ & N/A & N/A & $\begin{array}{l}\text { Expertise } \\
\text { Contemporaneous }\end{array}$ \\
\hline $\mathbf{Y}$ & N/A & N/A & None \\
\hline $\mathbf{N}$ & $\mathrm{N} / \mathrm{A}$ & N/A & Longstanding \\
\hline $\mathbf{Y}$ & N/A & N/A & $\begin{array}{l}\text { Longstanding } \\
\text { Expertise }\end{array}$ \\
\hline
\end{tabular}


103. Consolidated Rail Corp. v. Darrone, 465 U.S. 624 (1984)

104. NLRB v. Bildisco \& Bildisco, 465 U.S. 513 (1984)

105. Grove City College v. Bell, 465 U.S. 555 (1984)

106. Dickman v. Commissioner, 465 U.S. 330 (1984)

107. Commissioner v. Engle, 464 U.S. 206 (1984)

108. INS v. Phinpathya, 464 U.S. 183 (1984)

109. Bureau of Alcohol, Tobacco \& Firearms v. FLRA,

464 U.S. 89 (1983)

110. Rice v. Rehner, 463 U.S. 713 (1983)

111. Guardians Ass'n v. Civil Serv. Comm'n of N.Y., 463 U.S. 582 (1983)

112. Belknap, Inc. v. Hale, 463 U.S. 491 (1983)

113. Public Serv. Comm'n v. Mid-Louisiana Gas, 463 U.S. 319 (1983)

114. National Ass'n Of Greeting Card Publishers v. United States Postal Serv., 462 U.S. 810 (1983)

115. NLRB v. Transportation Management Corp. 462 U.S. 393 (1983)

116. Bell v. New Jersey, 461 U.S. 773 (1983)

117. Bill Johnson's Restaurants, Inc. v. NLRB, 461 U.S. 731 (1983)

118. Morrison-Knudsen Constr. Co. v. Director, Office of Workers' Compensation Programs, 461 U.S. 624 (1983)

119. Bob Jones Univ, y. United States, 461 U.S. 574 (1983)
$\mathbf{Y}$

$\mathrm{N}$

$\mathbf{Y}$

$\mathbf{Y}$

N

N

$\mathbf{N}$

N/A N/A

N/A N/A

Ratification

Expertise

N/A N/A

Longstanding

Ratification

N/A N/A None

N/A N/A None

1982 TERM

$\mathrm{Y}$ N/A

N/A

Contemporaneous

$\mathbf{Y}$

N/A N/A

Longstanding

Contemporaneous

N

N

N/A N/A None

$\mathbf{Y}$

N/A N/A

Longstanding

$\mathbf{Y}$

N/A N/A

Longstanding

$\mathbf{Y}$

N/A N/A

None

$\mathbf{N}$

$\mathbf{Y}$

N/A

N/A

Expertise

Longstanding

N/A N/A Longstanding

N/A N/A Ratification 
120. Heckler v. Campbell, 461 U.S. 458 (1983)

121. American Paper Inst, Inc. v. American Elec. Power Serv. Corp., 461 U.S. 402 (1983)

122. Commissioner v. Tufts, 461 U.S. 300 (1983)

123. Metropolitan Edison Co. v. NLRB, 460 U.S. 693 (1983)

124. Bowsher v. Mercli \& $\mathrm{CO}_{\text {. }}$ 460 U.S. 824 (1983)

125. Fidelity Fed. Sav. \& Loan Ass'n v. De La Cuesta, 458 U.S. 141 (1982)

125. Schweiker v. Hogan, 457 U.S. 569 (1982)

127. Blum v. Bacon, 457 U.S. 132 (1982)

128. North Haven Bd. of Educ. v. Bell, 456 U.S. 512 (1982)

129. Herwig v. Ray, 4S5 U.S. 265 (1982)

130. United States v. Vogel Fertilizer Co., 455 U.S. 16 (1982)

$\mathbf{N}$ 1981 TERM N/A N/A

Longstanding

Y

N/A N/A None

$\mathbf{Y}$

N/A N/A None

$\mathbf{Y}$

N/A

N/A

Longstanding

Ratification

Interagency

disagreement

$\mathbf{Y}$

N/A N/A

Legis/Interp.

131. United States v. Clark, 454 U.S. 555 (1982)

132. Charles D. Bonnano Linen Serv. v. NLRB, 454 U.S. 404 (1982)

133. NLRB v. Hendricks County Rural Elec. Mermbership Corp., 454 U.S. 170 (1981)

Y

N/A N/A

Longstanding

Ratification

Legis.Interp.

4. Ridgway v. Ridgway, 454 U.S. 46 (1981)

135. Federal Election Comm'n v. Democratic Senatorial Campaign Comm., 454 U.S. 27 (1981)

$\mathbf{Y}$

N/A

N/A

Longstanding

$\mathbf{Y}$

N/A N/A

Longstanding

Well-reasoned

Longstanding

Ratification

None

$\mathbf{Y}$

$\begin{array}{lll}\text { N/A N/A } & \begin{array}{l}\text { Longstanding } \\ \text { Well-reasoned } \\ \text { Expertise }\end{array}\end{array}$


